\title{
EMBALAGENS DE TRANSPORTE (MASTERPACK) COM ATMOSFERA MODIFICADA E ABSORVEDORES DE OXIGÊNIO PARA AUMENTO DA VIDA ÚTIL DE CARNE BOVINA
}

\author{
Anna Cecilia Venturini
}

Dissertação apresentada à Escola Superior de Agricultura "Luiz de Queiroz", Universidade de São Paulo, para obtenção do título de Mestre em Ciências. Área de Concentração: Ciência e Tecnologia de Alimentos

P I R A C I C A B A

Estado de São Paulo - Brasil

Fevereiro - 2003 


\title{
EMBALAGENS DE TRANSPORTE (MASTERPACK) COM ATMOSFERA MODIFICADA E ABSORVEDORES DE OXIGÊNIO PARA AUMENTO DA VIDA ÚTIL DE CARNE BOVINA
}

\author{
ANNa CECiLIA Venturini \\ Engenheira de Alimentos \\ Orientador: Prof ${ }^{a}$. Dr ${ }^{\mathrm{a}}$. CARMEN JOSEFINA CONTRERAS CASTILLO \\ Dissertação apresentada à Escola Superior de Agricultura \\ "Luiz de Queiroz", Universidade de São Paulo, para obtenção \\ do título de Mestre em Ciência e Tecnologia de Alimentos, \\ Área de Concentração: Ciências.
}

P I R A C I C A B A

Estado de São Paulo - Brasil

Fevereiro - 2003 
Dados Internacionais de Catalogação na Publicação (CIP) DIVISÃO DE BIBLIOTECA E DOCUMENTAÇÃO - ESALQ/USP

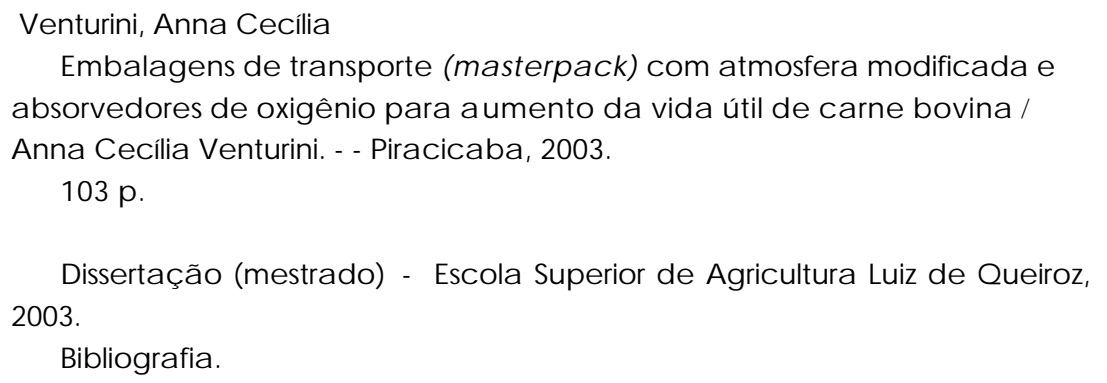

1. Alimentos de origem a nimal 2. Arma zenamento em a tmosfera modific ada 3. Conservação de a limentos 4. Conta mina ção de alimentos 5. Embalagens de alimentos 6. Microbiologia de alimentos 7. Vida-de-prateleira I. Título

CDD 664.902

\section{"Permitida a cópia total ou parcial deste documento, desde que citada a fonte - $O$ autor"}




\section{AGRADECIMENTOS}

À Prof. Dra. Carmen J. C. Contreras pela orientação, inestimável colaboração e amizade, fundamentais para a realização deste trabalho.

Em especial, à pesquisadora Claire I.G.L. Sarantópoulos pela valiosa contribuição.

À FAPESP que financiou a execução deste trabalho.

Ao CTC - ITAL, que permitiu a realização deste trabalho em suas instalações.

Aos estagiários Bruno, Nelisa, Cláudia, Denise e a todos os funcionários, pesquisadores e pós-graduandos do CTC - ITAL que colaboraram comigo para a realização deste trabalho.

À Standa Industrie pelos absorvedores de oxigênio e à Cryovac pelas bandejas de poliestireno e absorvedores de líquido concedidos.

A todos que de alguma maneira contribuíram com a realização deste trabalho. 
Dedico esta tese à minha família e em especial ao Narci pelo apoio de toda hora. 


\section{SUMÁRIO}

Página

LISTA DE FIGURAS................................................................ ix

LISTA DE TABELAS...................................................................

RESUMO .........................................................................

SUMMARY ..............................................................................

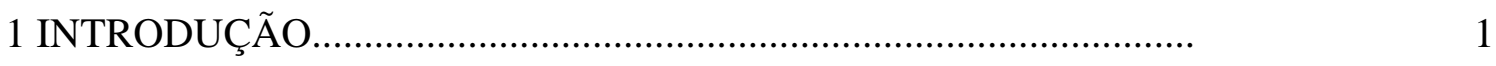

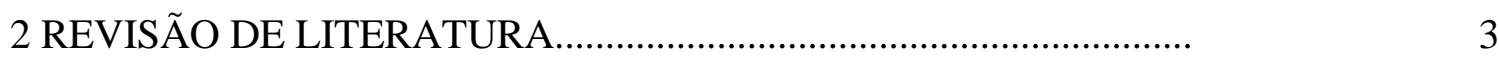

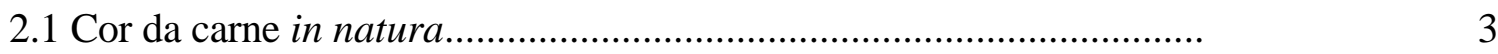

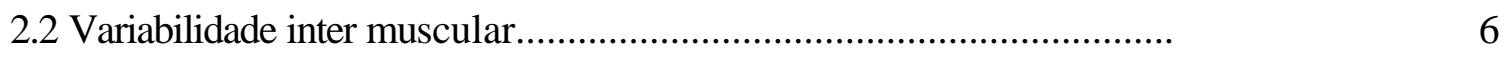

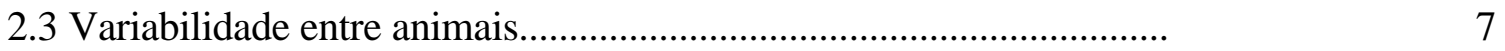

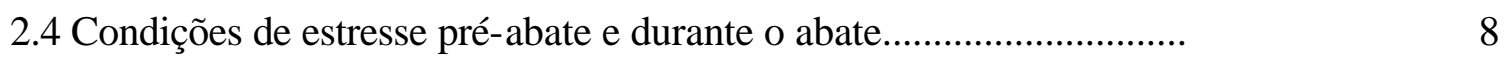

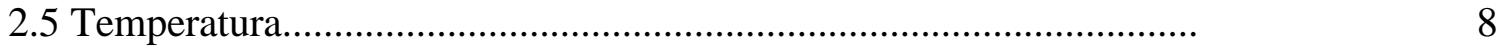

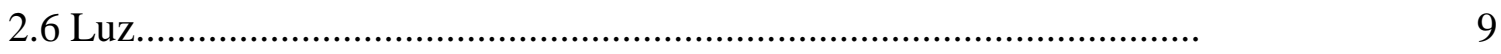

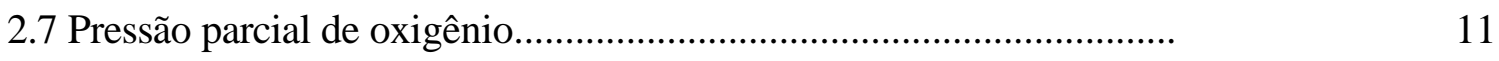

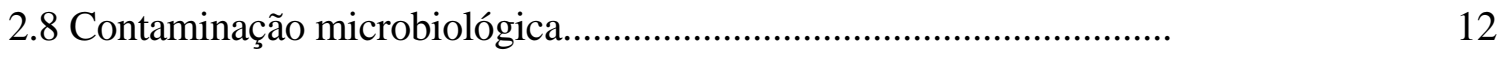

2.9 Sistema masterpack e vida de prateleira de carne refrigerada............... 14 


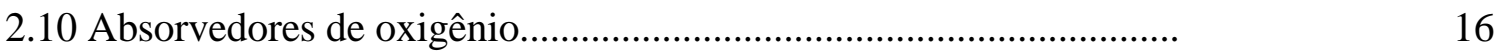

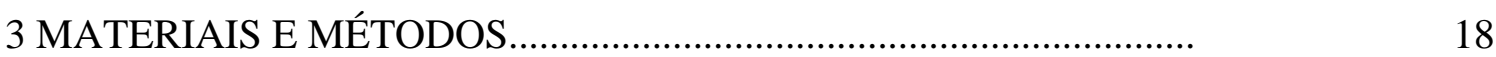

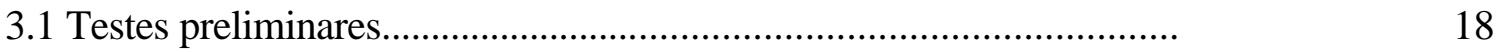

3.1.1 Seleção do tipo de bandeja e absorvedor de oxigênio....................... 19

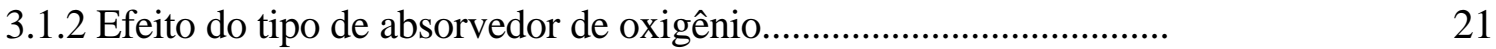

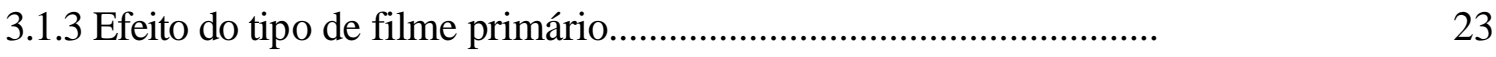

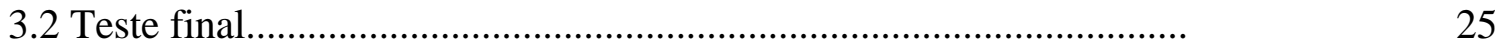

3.3 Descrição dos métodos utilizados para avaliação da vida útil............. 27

3.3.1 Avaliação do oxigênio residual nas embalagens masterpack ........... 27

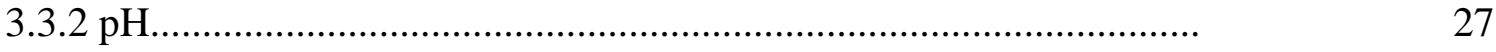

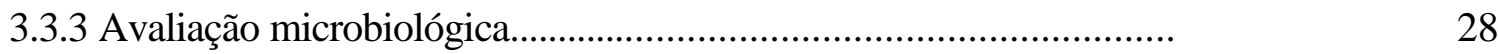

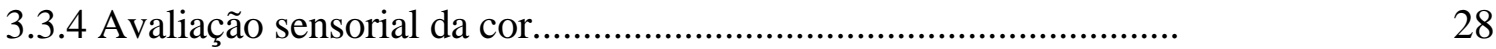

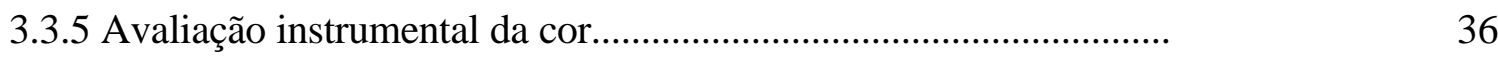

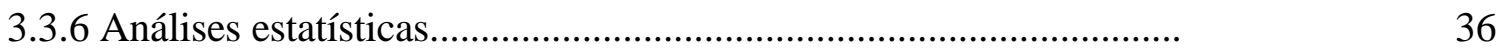

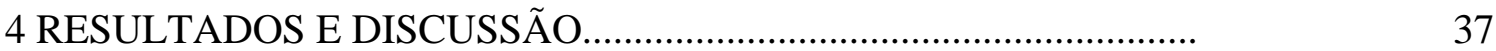

4.1 Efeito do tipo de bandeja plástica x absorvedor de oxigênio............... 37

4.1.2 Avaliação do oxigênio residual das embalagens mastepack ............ 37

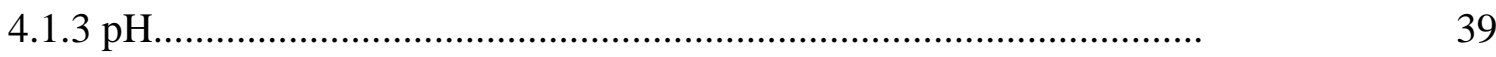

4.1.4 Caracterização microbiológica da matéria-prima............................. 40

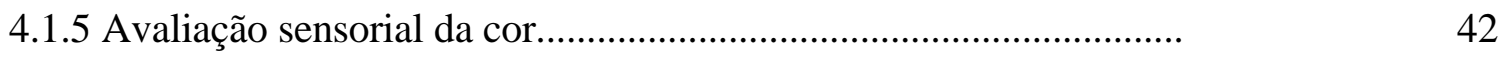

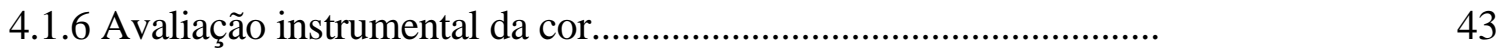


4.2.3 Caracterização microbiológica da matéria-prima.

4.2.4 Avaliações sensoriais e objetivas da cor do músculo. 
Página

4.4.5.1 Contra filé.....................................................................

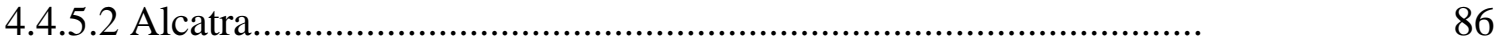

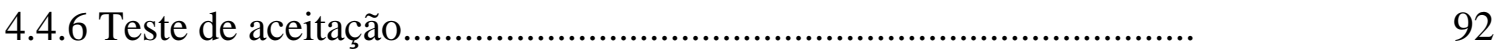

5 CONCLUSÕES

REFERÊNCIAS BIBLIOGRÁFICAS................................................. 


\section{LISTA DE FIGURAS}

Página

1 Estrutura química da mioglobina

2 Ficha sensorial aplicada aos julgadores treinados no teste preliminar para a escolha do filme primário.

3 Ficha sensorial aplicada à equipe treinada no teste final

4 Ficha sensorial aplicada no teste de aceitação.....................................

5 Teor de oxigênio residual no masterpack em função do tipo de bandeja

6 Teor de oxigênio residual no masterpack em função do tipo de

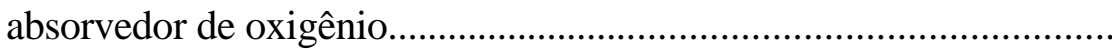

7 Teor de oxigênio residual no masterpack em função do tipo de filme primário

8 Valores médios de $\mathrm{pH}$ dos bifes de contra filé em função do tipo de filme primário 
9 Valores médios de $\mathrm{pH}$ dos bifes de contra filé em função do tipo de filme primário

10 Contagem de microrganismos psicrotróficos aeróbios nos bifes de contra filé em função do tipo de filme primário.

11 Contagem de microrganismos psicrotróficos aeróbios nos bifes de alcatra em função do tipo de filme primário

12 Contagem de microrganismos psicrotróficos anaeróbios nos bifes de contra filé em função do tipo de filme primário

13 Contagem de microrganismos psicrotróficos anaeróbios nos bifes de alcatra em função do tipo de filme primário.

14 Contagem de bactérias láticas nos bifes de contra filé em função do tipo de filme primário.

15 Contagem de microrganismos psicrotróficos aeróbios nos bifes de alcatra em função do tipo de filme primário

16 Efeito do tipo de filme primário sobre a cor vermelha subjetiva dos bifes de contra filé, após 1h de exposição aeróbica.

17 Efeito do tipo de filme primário sobre a cor vermelha instrumental (a*) dos bifes de contra filé, após 1h de exposição aeróbica

18 Efeito do tipo de filme primário sobre a luminosidade (L*) dos bifes de contra filé, após $1 \mathrm{~h}$ de exposição aeróbica. 
19 Efeito do tipo de filme sobre os valores de $b^{*}$ dos bifes de contra filé, após 1 de exposição aeróbica....................................................

20 Efeito do tipo de filme primário sobre a porcentagem de manchas dos bifes de contra filé, após 1h de exposição aeróbica......................

21 Efeito do tipo de filme primário sobre a cor rosa da gordura dos bifes de contra filé, após 1h de exposição aeróbica

22 Efeito do tipo de filme primário sobre a cor vermelha sensorial dos bifes de alcatra, após 1h de exposição aeróbica.

23 Efeito do tipo de filme primário sobre a cor vermelha instrumental (a*) objetiva dos bifes de alcatra, após 1h de exposição aeróbica.......

24 Efeito do tipo de filme primário sobre a luminosidade $\left(\mathrm{L}^{*}\right)$ dos bifes de alcatra, após 1h de exposição aeróbica.

25 Efeito do tipo de filme primário sobre os valores de $b^{*}$ dos bifes de alcatra, após 1h de exposição aeróbica.

26 Efeito do tipo de filme primário sobre a porcentagem de manchas dos bifes de alcatra, após 1h de exposição aeróbica.

27 Efeito do tipo de filme primário sobre a cor rosa da gordura dos bifes de alcatra, após $1 \mathrm{~h}$ de exposição aeróbica.

28 Teor residual de oxigênio de oxigênio no masterpack durante armazenamento a $1 \pm 1^{\circ} \mathrm{C}$ 
29 Valores médios de $\mathrm{pH}$ interno e externo dos bifes de contra filé em função do tempo de armazenamento..............................

30 Valores médios de $\mathrm{pH}$ interno e externo dos bifes de alcatra em função do tempo de armazenamento.............................

31 Contagem de bactérias psicrotróficas aeróbias, psicrotróficas anaeróbias e láticas nos bifes de contra filé

32 Contagem de bactérias psicrotróficas aeróbias, psicrotróficas anaeróbias e láticas nos bifes de alcatra.

33 Efeito do uso de absorvedores de oxigênio sobre a cor vermelha sensorial dos bifes de contra filé.

34 Efeito do uso de absorvedores de oxigênio sobre a cor vermelha sensorial dos bifes de contra filé

35 Efeito do uso de absorvedores de oxigênio sobre a cor vermelha instrumental dos bifes de contra filé

36 Efeito do uso de absorvedores de oxigênio sobre os valores de $\mathrm{L}^{*}$ dos bifes de contra filé, após 1, 24 e 48h de exposição aeróbica........

37 Efeito do uso de absorvedores de oxigênio sobre os valores de b* dos bifes de contra filé, após 1, 24 e 48h de exposição aeróbica........

38 Efeito do uso de absorvedores sobre a cor vermelha instrumental dos bifes de alcatra. 
39 Correlação entre os valores médios de cor vermelha subjetiva e a diferença de reflectância (R630 - R580) dos bifes de contra filé.

40 Efeito do uso de absorvedores sobre os valores de luminosidade

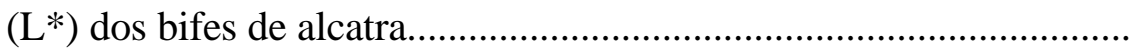

41 Efeito do uso de absorvedores sobre os valores de $b^{*}$ dos bifes de alcatra

42 Influência do tempo e do uso de absorvedor sobre a porcentagem de manchas dos bifes de alcatra.

43 Influência do tempo e do uso de absorvedor sobre a intensidade da cor rosa da gordura dos bifes de alcatra.

44 Amostras de contra filé armazenados por 42 dias sob $\mathrm{CO}_{2}$, acondicionados com e sem absorvedores de oxigênio

45 Amostras de alcatra armazenados por 42 dias sob $\mathrm{CO}_{2}$, acondicionados com e sem absorvedores de oxigênio

46 Porcentagem de aceitação dos bifes de contra filé acondicionados

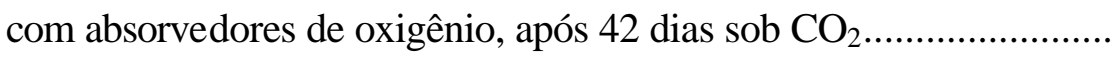

47 Porcentagem de aceitação dos bifes de contra filé acondicionados com absorvedores de oxigênio, após 42 dias sob $\mathrm{CO}_{2}$ 


\section{LISTA DE TABELAS}

Página

1 Estabilidade da cor de quatro músculos de carne bovina fresca acondicionados em ar a $5^{\circ} \mathrm{C}$

2 Constantes de oxidação para carne bovina refrigerada exposta à uma

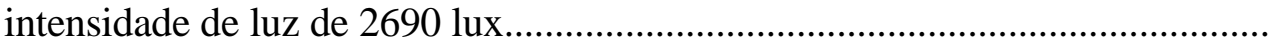

3 Vida útil da cor para picanha e coxão mole congelados.

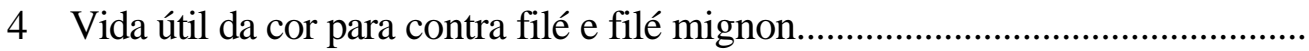

5 Valores médios (M) e desvio padrão (DP) de pH externo e interno dos bifes de contra filé

6 Valores médios (M) e desvio padrão (DP) de $\mathrm{pH}$ externo e interno dos bifes de alcatra.

7 Caracterização microbiológica inicial dos cortes de alcatra e contra filé 
8 Contagem de microrganismos psicrotróficos aeróbios e anaeróbios, após 14

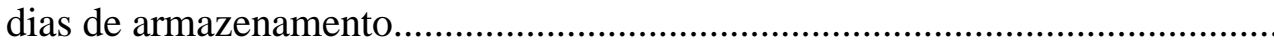

9 Valores médios (M) e desvio padrão (DP) dos valores de a* dos bifes de

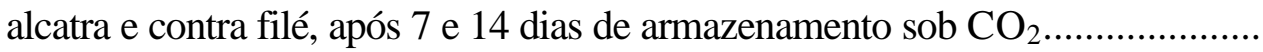

10 Valores médios (M) e desvio padrão (DP) dos valores de $\mathrm{L}^{*}$ dos bifes de alcatra e contra filé, após 7 e 14 dias de armazenamento sob $\mathrm{CO}_{2}$

11 Valores médios (M) e desvio padrão (DP) dos valores de b* dos bifes de alcatra e contra filé, após 7 e 14 dias de armazenamento sob $\mathrm{CO}_{2}$

12 Efeitos do uso de absorvedor de oxigênio e do tempo de armazenamento sob $\mathrm{CO}_{2}$, sobre os valores de $\mathrm{pH}$ dos bifes de alcatra

13 Caracterização microbiológica da matéria-prima

14 Efeitos do tipo de absorvedor de oxigênio sobre a contagem de microrganismos psicrotróficos aeróbios e anaeróbios dos bifes de alcatra........

15 Efeitos do uso de absorvedor de oxigênio e do tempo de armazenamento sob $\mathrm{CO}_{2}$, sobre os valores de $\mathrm{pH}$ dos bifes de alcatra.....

16 Caracterização microbiológica da matéria-prima utilizada no teste preliminar para escolha do tipo de filme primário. 


\section{EMBALAGENS DE TRANSPORTE (MASTERPACK) COM ATMOSFERA MODIFICADA E ABSORVEDORES DE OXIGÊNIO PARA AUMENTO DA VIDA ÚTIL DE CARNE BOVINA}

Autora: ANNA CECILIA VENTURINI

Orientadora: Prof ${ }^{\mathrm{a}}$. Dr ${ }^{\mathrm{a}}$. CARMEN JOSEFINA CONTRERAS CASTILLO

\section{RESUMO}

Os efeitos combinados do $\mathrm{CO}_{2}$ como agente bacteriostático e dos absorvedores de oxigênio, para obtenção de uma atmosfera virtualmente livre de oxigênio, foram explorados neste experimento. Bifes de alcatra e contra filé, acondicionados em bandejas de poliestireno expandido, foram envoltos por filme de alta permeabilidade ao oxigênio (PVC). Dois conjuntos de quatro bandejas foram sobrepostos no interior de embalagens de transporte com alta barreira a gases (masterpack) sob atmosfera com $\mathrm{CO}_{2}$ puro, armazenadas a $1 \pm 1^{\circ} \mathrm{C}$ por períodos de 14, 28, 35 e 42 dias. Para minimizar a descoloração durante o armazenamento foram adicionados sachês absorvedores de oxigênio no interior das embalagens masterpack, com capacidade nominal de seqüestrar $1000 \mathrm{~cm}^{3}$ de $\mathrm{O}_{2}$. Embalagens sem absorvedores (controle) foram preparadas da mesma maneira. Após cada período de armazenamento, as bandejas foram retiradas das embalagens masterpack e expostas ao ar atmosférico em balcão refrigerado com temperatura de $4 \pm 2^{\circ} \mathrm{C}$. A qualidade microbiológica, o desenvolvimento da cor vermelha do músculo, porcentagem de manchas, aparência e cor rosa da gordura foram avaliadas periodicamente para determinação do potencial de reavivamento da cor (reblooming). 
Ao longo do tempo de armazenamento, observou-se um aumento da fase lag de crescimento de bactérias psicrotróficas aeróbias nos bifes de contra filé e alcatra acondicionados com absorvedores de oxigênio. $\mathrm{O}$ crescimento de bactérias psicrotróficas anaeróbias e de bactérias láticas foi mais influenciado pelo armazenamento sob $\mathrm{CO}_{2}$ do que pelo uso de absorvedores de oxigênio. Os bifes acondicionados com absorvedores readquiriram coloração vermelha após exposição aeróbica, apresentaram menor proporção de manchas, foram os mais atrativos e exibiram valores de vermelho ( $\left.\mathrm{a}^{*}\right)$ e de R630-R580 superiores ao das amostras do tratamento controle, que geralmente não apresentaram potencial de reblooming após exposição aeróbica. Após 42 dias de armazenamento, os bifes de contra filé e alcatra foram considerados aceitáveis por 77 e $49 \%$ dos consumidores, respectivamente. 


\section{MASTERPACK SYSTEM WITH MODIFIED ATMOSPHERE (100\% $\left.\mathrm{CO}_{2}\right)$ AND OXYGEN SCAVENGERS TO EXTEND THE STORAGE LIFE OF FRESH MEAT}

Author: ANNA CECILIA VENTURINI Adviser: Prof ${ }^{a}$. Dr ${ }^{\mathrm{a}}$. CARMEN JOSEFINA CONTRERAS CASTILLO

\section{SUMMARY}

Masterpack system with modified atmosphere $\left(\begin{array}{lll}100 \% & \mathrm{CO}_{2}\end{array}\right)$ and oxygen scavengers to achieve a virtually oxygen-free atmosphere were used to prevent metmioglobin formation (brown) under surface of beef and to extend shelf-life of striploin and rump steaks packaged in polystyrene trays and over-wrapped with plastic film having a high permeability (PVC). The masterpacks were stored at $1 \pm 1^{\circ} \mathrm{C}$ for 14 , 28, 35 and 42 days. For each storage time, microbiological, red colour of muscles, \% discoloration, appearance and pink colour of fat characteristics were measured for assessment of reblooming in product stored with and without oxygen scavengers (controls). The increase in lag phase of psychrotrophic aerobic with increasing storage was mainly dependent on the use of scavengers oxygen. The psychrotrophic anaerobic and latic bacteria were more influenced by $\mathrm{CO}_{2}$ than that use of scavenger oxygen. The steaks stored with scavengers oxygen reblooming after aerobic exposure, showed less spot fractions, were the most attractive and red and R630-R580 values were higher than controls products, that failed to bloom. After 42 days of storage, the acceptability of striploin and rump steaks were 77 e $49 \%$, respectively. 


\section{INTRODUÇÃO}

Os consumidores utilizam a cor como parâmetro para identificar o frescor e a qualidade dos alimentos. Invariavelmente, desejam uma coloração vermelhobrilhante nos cortes de carne bovina fresca pré-embalados.

No Brasil, é altamente difundido o sistema que utiliza bandejas de poliestireno expandido, envoltas por filmes esticáveis de alta permeabilidade a gases, como o PVC - policloreto de vinila, para comercialização de carne refrigerada. No entanto, a vida útil do produto acondicionado neste tipo de sistema de embalagem é limitada a 2-3 dias, devido à oxidação da mioglobina e ao rápido crescimento de bactérias deteriorantes, principalmente Pseudomonas $s p$.

A possibilidade de aumento do tempo de armazenagem pela utilização do sistema de embalagens de transporte tipo masterpack com atmosfera modificada pode permitir a centralização do processamento de cortes de carne em bifes e promover a substituição da forma tradicional de distribuição de carcaças e quartos bovinos entre abatedouros e açougues, pela comercialização de cortes de carnes previamente preparados e embalados em centros de distribuição especialmente desenvolvidos.

Esse sistema pode prolongar a vida de prateleira dos cortes de carne, por meio do controle do crescimento microbiano e da oxidação dos pigmentos. Nas embalagens tipo masterpack sob atmosfera de $\mathrm{CO}_{2}$, a carne fica com coloração arroxeada, igual à da carne submetido ao vácuo, mas depois de abertas para a venda no varejo, a alta permeabilidade da embalagem primária permite que a superfície da carne readquira a coloração vermelha brilhante (fenômeno de reblooming), tão apreciada pelo consumidor. 
São inúmeras as vantagens para o consumidor na compra de carne fresca, certificada, cortada e pré-embalada em operações centralizadas, como por exemplo: variedade, conveniência, qualidade e segurança alimentar. Para os varejistas, a centralização das operações de corte e embalagem e a possibilidade de aumento do tempo de estocagem de bifes pré-embalados oferecem consideráveis vantagens econômicas, tais como redução de espaço-físico e diminuição de custos com mão-deobra e frete, além de atender às novas tendências de mercado.

O objetivo deste trabalho foi otimizar um sistema de embalagem de transporte tipo masterpack, com alto teor de $\mathrm{CO}_{2}$ e associados a absorvedores de oxigênio, para aumento da vida útil de bifes de alcatra e contra filé. 


\section{REVISÃO DA LITERATURA}

\subsection{Cor da carne in natura}

A cor é o principal parâmetro de avaliação da qualidade e frescor da carne bovina. Os consumidores preferem as carnes bovinas frescas e a coloração vermelhobrilhante é um atributo extremamente importante. Qualquer alteração da cor resulta em diminuição das vendas, reclamações e devolução de mercadorias. A curta vida útil das carnes frescas é a principal preocupação dos mercados varejistas. A cor da carne é determinada por dois fatores principais. O primeiro é a concentração e o estado dos pigmentos heme, mioglobina $(\mathrm{Mb})$ e hemoglobina $(\mathrm{Hb})$ e o segundo é a micro-estrutura do músculo.

Após a sangria, a mioglobina constitui $80-90 \%$ dos pigmentos totais da carne bovina. Em geral, teores mais altos de mioglobina são encontrados em músculos de animais com maior atividade. As diferenças de cor entre músculos e muitas das variações entre espécies são devido aos tipos de fibras musculares presentes.

A mioglobina é encontrada em altas concentrações nos tecidos musculares e sua propriedade funcional mais importante é a habilidade de ligar-se reversivelmente ao oxigênio molecular. A mioglobina é uma proteína globular complexa, formada por um polipeptídeo, a globina, e por um grupo prostético, chamado heme, responsável pela sua cor. Esse grupo heme consiste de um átomo central de ferro e de um anel porfirínico plano (Figura 1). 


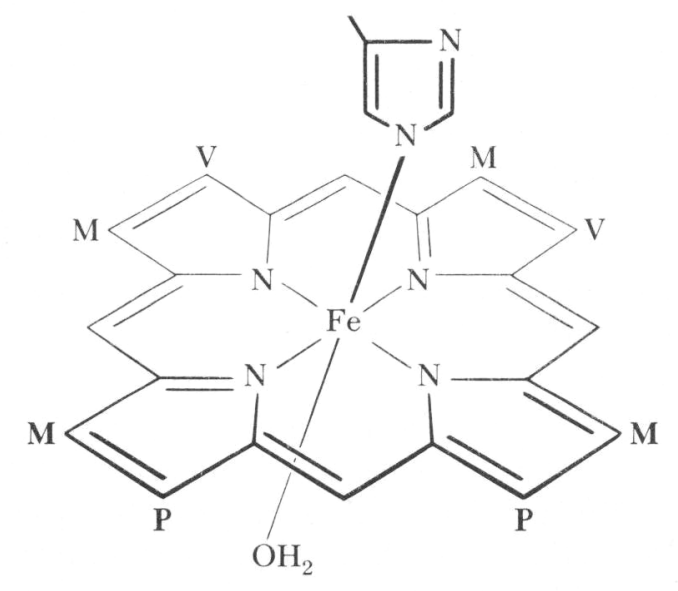

Figura 1- Estrutura química da mioglobina.

O anel porfirínico é composto por quatro anéis pirrólicos, unidos por pontes metilênicas (Kropf et. al., 1985). A cor da carne é particularmente dependente do estado químico (estado de oxidação) do ferro dentro do anel porfirínico da mioglobina. O íon ferroso $\left(\mathrm{Fe}^{+2}\right)$ dos heme pigmentos pode aceitar seis elétrons em seu orbital mais externo e formar seis ligações covalentes, quatro com os átomos de nitrogênio dos anéis pirrólicos do grupo heme e uma com a histidina $\mathrm{F} 8$, que liga o grupo heme à globina. $\mathrm{O}$ sexto elétron está disponível para ligação covalente com o oxigênio molecular responsável pela cor vermelha brilhante da oximioglobina. Essa reação é limitada a uma fina camada superficial que corresponde à profundidade da penetração do oxigênio. Uma vez formada a oximioglobina é estabilizada por uma estrutura altamente ressonante. Giddings (1977) realizou uma revisão detalhada sobre a química das reações do grupo heme com oxigênio. A nitrosomioglobina e carboximioglobina são exemplos de outros complexos covalentes formados entre o íon ferroso da mioglobina com o óxido nítrico e o monóxido de carbono.

A oxidação do íon ferroso à forma férrica $\left(\mathrm{Fe}^{+3}\right)$ resulta na formação de metamioglobina, marrom, que é incapaz de ligar-se ao oxigênio. Cerca de $20 \%$ de metamioglobina na superfície de carnes bovinas é suficiente para causar a rejeição dos produtos pelos consumidores. 
Além da quantidade e do estado de oxidação da mioglobina, a cor é determinada pelas propriedades de dispersão da luz pela carne. A ressonância das duplas ligações conjugadas do grupo heme é responsável pela habilidade da mioglobina em absorver luz visível. A mioglobina é caracterizada por uma banda de absorção com um máximo em $555 \mathrm{~nm}$ é sua cor é roxa. Na metamioglobina o maior pico ocorre em $505 \mathrm{~nm}$ e sua aparência visual é marrom. Qualquer tentativa para explicar a percepção visual da carne deve considerar não somente as características espectrais do pigmento, mas também as características de espalhamento e dispersão da luz pelo músculo.

O espalhamento da luz é influenciado por fatores estruturais e depende do grau de expansão das miofibrilas. A carne pale, soft and exsudative (PSE), por exemplo, possui uma alta capacidade de espalhar a luz, ou seja, a luz é espalhada antes que penetre na carne. Ao contrário, a carne dark, firm and dry (DFD), formada quando o $\mathrm{pH}$ final é alto $(>6,0)$ espalha luz somente numa pequena extensão. Neste caso, a luz incidente penetra na carne numa substancial profundidade e é fortemente absorvida pela mioglobina. Essa carne portanto, aparece escura.

Existem diversos sistemas de cores capazes de descrever como a cor é percebida (Hunter, Munsell, CIE-triestímulos). Essas descrições são úteis para seleção de critérios na pesquisa onde somente a descrição da cor é necessária. Tais descrições não são muito utilizadas nas pesquisas onde se deseja acompanhar as alterações de cor da carne, como no caso do estudo de vida útil de carne bovina armazenada sob atmosfera modificada. Considerando que a percepção da cor da carne é devida principalmente à reflexão difusa da luz incidente, os espectros de reflectância estão diretamente relacionados com o estado químico da mioglobina, e conseqüentemente, demonstram uma informação extremamente útil a respeito de como um tratamento afeta a estabilidade da cor vermelha.

O método da diferença entre R630-R580 mede a proporção relativa de oximioglobina em relação à metamioglobina. Uma boa metodologia de avaliação instrumental da cor de carne vermelha deve ter uma alta correlação com a avaliação sensorial. (Hunt, 1980). 
$\mathrm{Na}$ ausência de oxigênio, predomina a forma reduzida do pigmento $(\mathrm{Mb})$ que apresenta coloração vermelho-púrpura típica de carnes embaladas a vácuo. Quando exposta ao ar a $\mathrm{Mb}$ combina-se com o oxigênio, formando a $\mathrm{MbO}_{2}$ de coloração vermelho-brilhante, sinônimo de frescor e qualidade para o consumidor. A MetMb é o pigmento marrom acinzentado, formado a partir da oxidação do íon ferroso $\mathrm{Fe}^{++}$para íon férrico $\mathrm{Fe}^{+++}$.

Considerando-se a importância da coloração na comercialização de carne fresca, torna-se desejável o conhecimento dos fatores mais significativos na determinação da cor. Durante a estocagem, a taxa de formação de MetMb na superfície da carne depende de vários fatores intrínsecos ( $\mathrm{pH}$, tipo de músculo, animal, raça, sexo, dieta, etc.) e extrínsecos (manejo pré-abate e durante o abate, estimulação elétrica, desossa à quente etc.). Durante a exposição ao varejo fatores físicos influenciam a aparência da carne fresca: temperatura, tipo de luz, disponibilidade de oxigênio, desenvolvimento microbiano, além das condições de armazenamento (ar, atmosfera modificada, vácuo).

Em um alimento complexo como a carne, a interação entre os fatores e o conhecimento a respeito dessas interações contribuem significativamente para a diminuição do problema de descoloração da carne (Gill \& Jones, 1994a).

\subsection{Variabilidade inter muscular}

É o fator isolado mais importante na estabilidade da cor da carne, excluindo-se a possibilidade de contaminação bacteriana (Hood, 1980). Tecidos musculares deficientes em enzimas ou cofatores necessários para a redução da forma oxidada serão incapazes de reconverter a MetMb, que persistirá uma vez formada. Diferentes tecidos musculares podem apresentar diferentes capacidades de redução da MetMb. Músculos com maior capacidade de redução apresentam coloração relativamente mais estável quando expostos ao ar (O'Keefe \& Hood, 1981b).

Segundo Ledward (1971), a susceptibilidade quanto à formação de MetMb no músculo é dada por: Bicepis femoris (picanha) > Semimembranosus (coxão mole) > Longissimus dorsi (contra filé) = Semitendinosus (lagarto). Similarmente, O’Keeffe \& 
Hood (1980) observaram que a variabilidade intermuscular foi o fator mais importante na estabilidade da cor de carne bovina pré-embalada e encontraram a seguinte ordem de estabilidade para os músculos estocados em temperaturas entre 0 e $10^{\circ} \mathrm{C}: 1^{\circ}$ ) Longissimus dorsi (contra filé), $2^{0}$ ) Semimembranosus (coxão mole), $3^{\circ}$ ) Gluteus medius (alcatra), $4^{\circ}$ ) Psoas major (filé mignon), sendo este último, o músculo mais instável à oxidação do pigmento (Tabela 1).

Tabela 1. Estabilidade da cor de quatro músculos de carne bovina acondicionados em ar a $5^{\circ} \mathrm{C}$.

\begin{tabular}{|c|c|c|}
\hline \multirow{2}{*}{ Músculo } & \multicolumn{2}{|c|}{ Vida útil (dias) 1} \\
\hline & Média $^{2}$ & Erro Padrão \\
\hline Filé mignon & $1,5^{\mathrm{a}}$ & 0,25 \\
\hline Alcatra & $4,4^{b}$ & 0,34 \\
\hline Contra filé & $6,6^{\mathrm{c}}$ & 0,83 \\
\hline Coxão Mole & $6,4^{\mathrm{c}}$ & 0,58 \\
\hline
\end{tabular}

Fonte: O'Keeffe \& Hood (1981a).

${ }^{1}$ Tempo (dias) para acúmulo de $20 \%$ de metamioglobina.

${ }^{2}$ Valores médios com letras diferentes diferem significativamente $(\mathrm{P}<0,05)$.

A classificação de Renerre (1990) embora mais completa, foi concordante com as anteriores e pode ser assim classificada: Longissimus dorsi (contra filé), Obliquus externus (ponta de agulha/costela) e Tensor fasciae latae (maminha) são os músculos mais estáveis. Semi-membranosus (coxão mole) é de estabilidade intermediária, enquanto que Gluteus medius (alcatra), Supra-spinatus (paleta), Psoas major (filé mignon) e Diaphragma medialis (fraldinha) são os menos estáveis à oxidação.

\subsection{Variabilidade entre animais}

A variabilidade entre animais é influenciada pela idade cronológica, sexo, raça, tipo de atividade física e grau de exercícios na criação, alimentação e atividade de enzimas mitocondriais, associadas à respiração aeróbica (citocromo oxidase e desidrogenase succínica). Contudo, a influência de fatores biológicos (idade, raça, sexo) 
sobre a cor da carne pode ser explicada pelas propriedades específicas dos diferentes tipos metabólicos das fibras musculares. Ao longo do período do nascimento do animal até 24 meses de idade, a concentração de mioglobina nos músculos aumenta e os músculos utilizados para a locomoção apresentam coloração mais escura. Paralelamente à idade cronológica, há um aumento da capacidade de metabolismo aeróbico que leva a um aumento significativo de fibras vermelhas em relação às brancas. Em carnes de animais mais velhos, a camada de oximioglobina diminui e, consequientemente, a superfície da carne é mais escura (Renerre, 1990).

\subsection{Condições de estresse pré-abate e durante o abate}

Quando o animal é submetido ao estresse, há uma redução do teor de glicogênio e uma elevação do pH, resultando numa carne escura, dura e seca. Há duas possíveis razões para o escurecimento da cor. As proteínas miofibrilares da carne com $\mathrm{pH}$ alto tem uma maior capacidade de se ligar à água do que a carne com pH normal $(5,6-5,8)$, resultando numa estrutura fechada que inibe difusão do oxigênio e apresenta baixa dispersão da luz, comparativamente às estruturas mais abertas das carnes com $\mathrm{pH}$ normal (Faustman \& Cassens, 1990). A segunda possibilidade para uma aparência mais escura da carne em $\mathrm{pH}$ elevado é relacionada com a atividade mitocondrial. A citocromo oxidase mitocondrial é mais ativa em $\mathrm{pH}$ elevados e o aumento do consumo de oxigênio aumenta a concentração de $\mathrm{Mb}$, impedindo o desenvolvimento da característica coloração vermelho-brilhante, quando a carne for exposta ao ar. Normalmente, a glicólise post mortem ocorre em $\mathrm{pH}<5,8$, que impede o consumo de oxigênio mitocôndrial e permite o desenvolvimento da cor vermelho brilhante da carne exposta ao ar (Egbert \& Conforth, 1986).

\subsection{Temperatura}

O aumento da temperatura diminui a solubilidade do oxigênio no músculo, favorecendo a formação da $\mathrm{Mb}$, mais suscetível à oxidação que a $\mathrm{MbO}_{2}$ (Giddings, 
1977; Kropf et al., 1985). Paralelamente, elevadas temperaturas resultam em aumento do consumo de oxigênio mitocondrial, aumento do crescimento microbiano e aceleração da oxidação lipídica, que contribuem para o aumento da descoloração (Faustman \& Cassens, 1990). Em baixas temperaturas aumenta-se a absorção de $\mathrm{CO}_{2}$ pela carne acondicionada nas embalagens com atmosfera modificada, inibindo o desenvolvimento de microrganismos aeróbicos e controlando o crescimento de organismos anaeróbicos ou anaeróbicos facultativos (Zhao et al., 1994). A temperatura ótima de estocagem de cortes de carne pré-embalada é a temperatura mínima em que o produto pode ser refrigerado sem que haja congelamento, isto é, $-1,5 \pm 0,5^{\circ} \mathrm{C}$.

\section{$2.6 \mathrm{Luz}$}

O armazenamento no escuro ajuda a preservar cor vermelha da carne fresca. A princípio, a degradação da cor está associada com o calor dissipado pelas lâmpadas dos balcões expositores. A luz UV rapidamente descolore a carne (Hutchings 1994). Lâmpadas incandescentes e fluorescentes de 2690 lux de intensidade aceleram a taxa de oxidação dos pigmentos de carnes pré-embaladas. A formação da cor marrom pode ser descrita em termos das taxas de oxidação e a Tabela 2 compara as constantes das taxas de oxidação para cinco condições de iluminação (Saterlee and Hansmeyer, 1974).

Tabela 2. Constantes de oxidação para carne bovina exposta a uma intensidade de luz de 2690 lux.

\begin{tabular}{lc}
\hline Fonte de luz & Constante da taxa de oxidação $\left(\mathrm{h}^{-1}\right)$ \\
\hline Nenhuma luz & $3,25 \times 10^{-3}$ \\
Luz incandescente fria (150W) & $5,16 \times 10^{-3}$ \\
Incandescente (100W) & $5,46 \times 10^{-3}$ \\
Fluorescente rosa (40W) & $5,54 \times 10^{-3}$ \\
Fluorescente branca (40W) & $8,20 \times 10^{-3}$ \\
\hline
\end{tabular}

Fonte: adapatado de Hutchings (1994). 
A luz branca fluorescente acarreta maior descoloração do que a luz incandescente. Giddings (1977) sugeriu que a oxidação do pigmento seria induzida pela fotooxidação da mioglobina. A iluminação imprópria da carne também leva à perda da cor vermelha. Kropf (1980) comentou que, da análise da energia espectral das lâmpadas, não encontrou nenhuma razão para a menor estabilidade da cor produzida pelas lâmpadas incandescentes e fluorescentes. A luz fluorescente branca tem grande emissão na região do UV, e a luz incandescente fria e branca na região do amarelo. Embora a carne estocada no escuro a $-1,1^{\circ} \mathrm{C}$ retém a cor, sua subseqüente exposição à luz causa mais rápida degradação. As diferenças foram atribuídas ao aumento do crescimento microbiano sobre a superfície da carne exposta (Marriot et al.,1967). As bactérias acarretariam uma diminuição da tensão de oxigênio na superfície da carne, causando uma rápida conversão da oximioglobina (vermelho) à metamioglobina (marrom).

Segundo Hutchings (1994), a saturação da cor pode definir e determinar a vida útil da carne fresca. Na formação da metamioglobina, a saturação $(\mathrm{S})$ diminui à medida que a cor muda de vermelho brilhante para vermelho escuro, e de marrom para marrom esverdeado. A variação de vermelho brilhante para vermelho escuro corresponde a $\mathrm{S}=20$. O valor de 18 corresponde a $20 \%$ de metamioglobina, quantidade suficiente para a rejeição pelo consumidor (Hutchings, 1994). Uma amostra claramente marrom (40\% de metamioglobina) tem um valor de $S=14$. O tempo de maturação aumenta a taxa de perda da saturação. A vida útil da cor também pode ser estendida em temperaturas de congelamento (Tabela 3). A vida útil de dois tipos de músculos bovinos sob vários tratamentos são apresentados na Tabela 4. 
Tabela 3. Vida útil da cor (dias) para picanha e coxão mole congelados.

\begin{tabular}{ccccc}
\hline $\begin{array}{c}\text { Intensidade } \\
\text { (lux })\end{array}$ & -7 & -18 & -29 & -40 \\
\hline 0 & $15-30$ & $>90$ & $>90$ & $>90$ \\
20 & $10-15$ & 30 & 90 & $>90$ \\
50 & $10-15$ & $10-30$ & $30-90$ & $>90$ \\
100 & 10 & $5-10$ & $10-30$ & $>90$ \\
250 & $1-3$ & $2-10$ & $10-30$ & $>90$ \\
500 & $1-3$ & $1-3$ & $10-30$ & $>90$ \\
1000 & 1 & $1-3$ & 15 & $>90$ \\
2000 & $<1$ & 1 & $3-5$ & $>90$
\end{tabular}

Fonte: adapatado de Hutchings (1994).

Tabela 4. Vida útil da cor (dias) para contra filé e filé mignon.

\begin{tabular}{cccccccc}
\hline $\begin{array}{c}\text { Tipo de } \\
\text { músculo }\end{array}$ & Semanas & Tratamento & \multicolumn{2}{c}{ Exposição } & \multicolumn{3}{c}{ Saturação da cor } \\
& & & ${ }^{\circ} \mathrm{C}$ & lux & $\begin{array}{c}\text { Valor } \\
\text { inicial }\end{array}$ & $\begin{array}{c}\text { Dias para } \\
\text { S=0 }\end{array}$ & $\begin{array}{c}\text { Dias para } \\
\text { S=20 a 16 }\end{array}$ \\
\hline Contra filé & 1 & Refrigerada & 5 & 1000 & 23 & 5,5 & 5 \\
& 3 & Refrigerada & 5 & 1000 & 25 & 5 & 5 \\
& 2 & Congelada & -18 & 500 & $>20$ & $<1$ & 3 \\
Filé mignon & 1 & Refrigerada & 5 & 1000 & 25 & 2 & 3,5 \\
& 3 & Refrigerada & 5 & 1000 & 25 & 1 & 2,5 \\
\hline
\end{tabular}

Fonte: adapatado de Hutchings (1994).

\subsection{Pressão parcial de oxigênio}

A formação de MetMb em baixas concentrações de $\mathrm{O}_{2}$ foi amplamente relatada (O’Keeffe \& Hood, 1981a; Renerre, 1990; Penney \& Bell, 1993; Gill \& Mc Ginnis, 1995). O’Keeffe \& Hood (1981b) demonstraram que níveis de $\mathrm{O}_{2}$ inferiores a $0,1 \%$ foram requeridos para prevenir a formação de MetMb em bifes de carne bovina (Psoas major (filé mignon), Gluteus medius (alcatra), Semimembranosus (coxão mole) durante 
estocagem em atmosfera de $\mathrm{CO}_{2}$ a $0^{\circ} \mathrm{C}$ por até 3 semanas. Geralmente, concentrações de cerca de $0,01 \%$ de $\mathrm{O}_{2}$ são suficientes para que ocorra uma rápida descoloração na superfície de músculos com baixa capacidade redutora, independente da temperatura de estocagem (Gill \& Mc Ginnis, 1995). Músculos com alta estabilidade de cor, como o Longissimus dorsi (contra filé), podem tolerar concentrações residuais de oxigênio de cerca de $0,04 \%$, sem descoloração, em temperaturas inferiores a $-1^{\circ} \mathrm{C}$, mas apresentamse completamente descoloridos quando estocadas a $2^{\circ} \mathrm{C}$ (Gill,1996).

$\mathrm{Na}$ prática, é muito difícil obter uma atmosfera completamente livre de $\mathrm{O}_{2}$ utilizando-se embalagens masterpack com injeção de $\mathrm{CO}_{2}$. Assim, logo após o fechamento desses tipos de embalagens o $\mathrm{O}_{2}$ residual é absorvido pela carne e há formação de MetMb na superfície do alimento (Ledward, 1970). A MetMb formada poderá ser reconvertida à $\mathrm{Mb}$ pela atividade de enzimas ou cofatores presentes no tecido muscular, permitindo a reaquisição da coloração vermelho-brilhante, quando a carne for retirada da embalagem masterpack e exposta ao ar. No entanto, a redução enzimática da MetMb é limitada e só ocorre após decorrido 2 a 3 dias, dependendo da concentração inicial de $\mathrm{O}_{2}$ no espaço livre das embalagens masterpack. Tal descoloração, mesmo que transitória, é altamente indesejável quando condições comerciais requerem rápidos períodos de distribuição e exposição ao varejo.

\subsection{Contaminação microbiológica}

Pseudomonas sp. constituem a maior fração da microflora de carnes embaladas com filmes altamente permeáveis ao $\mathrm{O}_{2}$, podendo multiplicar-se rapidamente em concentrações de até $1 \%$ de oxigênio. A vida útil dos produtos expostos ao ar é limitado a poucos dias (Borch et al., 1996). Segundo Robach \& Costilow, citados por Faustman \& Cassens (1990), a intensidade da descoloração da carne é decorrente do número de bactérias aeróbias presentes, responsáveis pela redução da tensão de oxigênio sobre a superfície da carne. Durante a estocagem sob atmosfera modificada, o efeito combinado do $\mathrm{CO}_{2}$ como agente bacteriostático e dos absorvedores do $\mathrm{O}_{2}$ utilizados para reduzir a concentração residual de $\mathrm{O}_{2}$, contribuíram para inibir o rápido crescimento de espécies 
psicrotróficas estritamente aeróbias, como as Pseudomonas que invariavelmente dominam a flora da carne armazenada em ar. Esses organismos, limitam a vida útil de carnes frescas pela produção de compostos de odores desagradáveis provenientes do metabolização de aminoácidos. Outras bactérias deteriorantes como enterobactérias e $B$. thermosphacta também são inibidas em atmosferas de $100 \% \mathrm{CO}_{2}$. Sob $100 \% \mathrm{CO}_{2}$ favorece-se crescimento de bactérias anaeróbias facultativas deteriorantes, principalmente bactérias láticas, enterobactérias psicrotróficas e B. thermosphacta, que se desenvolvem numa taxa relativamente mais lenta. Contudo, Hood \& Mead (1993) recomendam um severo controle de temperatura para prevenir o crescimento de bactérias anaeróbicas capazes de produzirem toxinas em atmosferas modificadas livres de $\mathrm{O}_{2}$, como por exemplo, certos tipos de C. botulinum (não-proteolíticos), que têm capacidade de crescer e produzir toxinas em temperaturas que variam entre 3,3 e $5^{\circ} \mathrm{C}$.

A habilidade de crescimento microbiano em função de diferentes condições ambientais diminui na seguinte ordem: ar, atmosfera modificada com alto teor de $\mathrm{O}_{2}$, vácuo, atmosfera modificada livre de $\mathrm{O}_{2}$ e $100 \% \mathrm{CO}_{2}$ (Borch et al. 1993). Gill \& Jones (1994a) compararam a "vida de prateleira" de bifes de carne bovina usando embalagens a vácuo $\left(-1,5^{\circ} \mathrm{C}\right)$ e masterpack $\left(2^{\circ} \mathrm{C}\right)$ sob atmosfera de $\mathrm{N}_{2}, \mathrm{CO}_{2}$ e $\mathrm{O}_{2}+\mathrm{CO}_{2}$. Após um período de estocagem de 60 dias, a flora dos bifes estocados sob $\mathrm{CO}_{2}$ foi totalmente composta por bactérias láticas. Pequenas frações $(<5 \%)$ de enterobactérias e $B$. thermosphacta estavam presentes nos produtos estocados a vácuo, enquanto que grandes frações $(>20 \%)$ de enterobactérias ou $B$. thermosphacta estavam presentes na flora dos bifes estocados sob atmosfera de $\mathrm{O}_{2}+\mathrm{CO}_{2}$. Posteriormente, Gill (1996) concluiu que somente em temperaturas inferiores a $0^{\circ} \mathrm{C}$ seria possível assegurar o crescimento de uma microflora composta inteiramente de Lactobacillus sp., em atmosferas contendo $100 \% \mathrm{CO}_{2}$, além de tipos mesófilos e estritamente aeróbios que predominavam na flora inicial.

Segundo Gill \& Jones (1994b), o desenvolvimento de odores levemente ácidos produzidos pelas bactérias láticas, sob condições anaeróbias, só é detectável quando a contagem é próxima ou superior a $5 \log \mathrm{UFC} / \mathrm{g}$, enquanto que o odor pútrido ou azedo é 
observável somente quando o número de bactérias aeróbias é igual ou superior a 6 $\log \mathrm{UFC} / \mathrm{g}$.

\subsection{Sistema masterpack e vida de prateleira de carne refrigerada}

$\mathrm{Na}$ venda de cortes de carne no Brasil é altamente difundido o método convencional de acondicionamento em ar, que utiliza bandejas plásticas envoltas em filmes esticáveis de alta permeabilidade ao oxigênio como o PVC - policloreto de vinila. No entanto, a descoloração e a microbiota composta principalmente por Pseudomonas sp. limitam a vida de prateleira do produto de 2 a 4 dias, dependendo da temperatura de refrigeração. Comercialmente, o tempo entre o acondicionamento da carne num sistema centralizado e sua exposição ao varejo, considerando as flutuações de demanda, é de cerca de 3 semanas. No acondicionamento a vácuo, a vida útil da carne é de aproximadamente 3 a 4 semanas, dependendo da temperatura de estocagem. Porém, a carne apresenta coloração roxa e grande quantidade de exsudado, deixando de ser atrativa para o consumidor. Além disso, a embalagem a vácuo exige posteriores operações de corte e re-embalagem em bandejas envoltas por filmes de alta permeabilidade ao oxigênio nos pontos de venda de auto-serviço.

O uso de embalagens masterpack em conjunção com atmosfera modificada parece ser uma boa opção para o acondicionamento de bifes pré-embalados. A escolha do gás ou da mistura gasosa para modificação da atmosfera é influenciada pela flora microbiana capaz de se desenvolver no produto, sensibilidade do produto ao oxigênio ou dióxido de carbono e estabilidade do pigmento à oxidação. Os gases normalmente usados para modificação da atmosfera são $\mathrm{O}_{2}, \mathrm{~N}_{2}$ e $\mathrm{CO}_{2}$ (Hood e Mead, 1993). As funções de cada gás usado em atmosfera modificada é a seguinte:

a) $\mathrm{CO}_{2}$, inibição do crescimento bacteriano e seleção de bactérias láticas;

b) $\mathrm{O}_{2}$, manutenção das características de cor da carne;

c) $\mathrm{N}_{2}$, gás de enchimento e/ou diluente.

Scholtz et al. (1992) compararam a vida de prateleira de cortes de lombo suíno embalados em masterpack sob atmosfera de $25 \% \mathrm{CO}_{2}+75 \% \mathrm{O}_{2}$ com amostras 
estocadas sob $100 \% \mathrm{CO}_{2}$. Todas as amostras foram estocadas a $0^{\circ} \mathrm{C}$ por 21 dias. As amostras estocadas sob $25 \% \mathrm{CO}_{2}+75 \% \mathrm{O}_{2}$ foram consideradas aceitáveis até 7 dias após o acondicionamento e exposição ao varejo. Os ensaios com $100 \% \mathrm{CO}_{2}$ produziram resultados promissores: as amostras estocadas por 21 dias foram consideradas aceitáveis por mais 4 dias após a abertura da embalagem masterpack. A vida de prateleira foi limitada pela aceitabilidade da cor da superfície dos cortes de lombo suíno.

Gill \& Jones (1994a) avaliaram a vida útil de carne bovina moída acondicionada em embalagens tipo masterpack sob várias atmosferas. Os produtos estocados sob $100 \%$ $\mathrm{N}_{2}$ ou $100 \% \mathrm{CO}_{2}$ não apresentaram descoloração ou odor estranho por 24 dias, e permaneceram atraentes por $12 \mathrm{~h}$ de exposição após 30 dias ou mais de estocagem a $-1,5^{\circ} \mathrm{C}$. Em contrapartida, as amostras sob atmosfera rica em oxigênio, $\mathrm{O}_{2}+\mathrm{CO}_{2}(2: 1$ v/v) apresentaram alta proporção de MetMb e foram consideradas indesejádas após 8 dias de estocagem.

Gill \& Jones (1994b) verificaram que bifes de contra filé estocados sob atmosfera de $\mathrm{CO}_{2}$ por até 4 dias, apresentaram descoloração superficial superior aos bifes estocados sob atmosfera de $\mathrm{CO}_{2}+\mathrm{O}_{2}$, após ambos serem retirados da atmosfera modificada e expostos ao ar. Posteriormente, entre 4 e 39 dias de estocagem sob $\mathrm{CO}_{2}$, a $\mathrm{MetMb}$ formada foi suficientemente reduzida à $\mathrm{Mb}$ pela atividade redutora de enzimas e cofatores do tecido muscular, que readquiriu a coloração vermelho-brilhante típica de carne fresca, após 1 hora de exposição ao ar (reblooming). No entanto, os bifes estocados sob atmosfera $\mathrm{CO}_{2}+\mathrm{O}_{2}$ apresentaram aparência deteriorada quando expostos ao ar, após 12 dias de estocagem em atmosfera modificada.

$\mathrm{O} \mathrm{CO}_{2}$ pode diminuir o $\mathrm{pH}$ da carne através da reação com a água e formar ácido carbônico. $\mathrm{O}$ efeito inibitório do $\mathrm{CO}_{2}$ manifesta-se por aumento da fase lag e aumento do tempo de geração durante a fase $\log$, porém a maneira como o $\mathrm{CO}_{2}$ inibe o crescimento celular não é bem conhecido (Hood \& Mead, 1993). A solubilidade do $\mathrm{CO}_{2}$ no tecido muscular e na gordura da carne e a inibição do desenvolvimento microbiano aumenta com a redução da temperatura (Gill, 1988).

O efeito do dióxido de carbono sobre microrganismos patogênicos não tem sido muito pesquisado, provavelmente porque esses organismos não crescem, ou se 
desenvolvem muito lentamente na temperatura normal de armazenamento e distribuição de produtos perecíveis como a carne $\left(0^{\circ}-10^{\circ} \mathrm{C}\right)$. A temperatura mínima para $\mathrm{o}$ crescimento de Salmonella é cerca de $5,3^{\circ} \mathrm{C}$, de Staphylococcus aureus $6,7^{\circ} \mathrm{C}$, e de Clostridium perfringens $12^{\circ} \mathrm{C}$. O rápido crescimento de microrganismos psicrotróficos, normalmente presente em alimentos perecíveis como a carne reduz, por inibição competitiva, a taxa de crescimento de patógenos em temperaturas abusivas.

\subsection{Absorvedores de oxigênio}

O nível de oxigênio residual no espaço livre das embalagens pode ser afetado por uma série de fatores tais como permeabilidade do material de embalagem, difusão do oxigênio no músculo, evacuação inadequada do ar ocluso entre os bifes e entre os bifes e a bandeja, ar ocluso na bandeja de plástico expandido e falta de hermeticidade no fechamento da embalagem. $\mathrm{O}$ uso de filmes com incorporação de absorvedores de $\mathrm{O}_{2}$ ou

sachês contendo substâncias facilmente oxidáveis permitem reduzir a concentração de $\mathrm{O}_{2}$ abaixo dos níveis críticos para a descoloração (Gill \& Mc Ginnis, 1995 e Labuza \& Breene, 1989). A maioria dos absorvedores de oxigênio disponíveis comercialmente é baseado no princípio de oxidação do ferro e são encontrados na 6rma de pequenos sachês, contendo agentes redutores como óxido de ferro, componentes ferrosos ou platina, combinados com vários catalisadores que dão início à reação:

$$
\begin{aligned}
& \mathrm{Fe} \rightarrow \mathrm{Fe}^{2+} \\
& 1 / 2 \mathrm{O}_{2}+\mathrm{H}_{2} \mathrm{O}+2 \mathrm{e}^{-} \rightarrow 2 \mathrm{OH}^{-} \\
& \mathrm{Fe}^{2+}+2 \mathrm{OH}^{-} \rightarrow \mathrm{Fe}(\mathrm{OH})_{2} \\
& \mathrm{Fe}(\mathrm{OH})_{2}+1 / 4 \mathrm{O}_{2}+1 / 2 \mathrm{H}_{2} \mathrm{O} \rightarrow \mathrm{Fe}(\mathrm{OH})_{3}
\end{aligned}
$$

Os sachês, feitos de materiais permeáveis ao ar, são colocados no interior das embalagens onde reagem com vapor de água proveniente dos alimentos, formando agentes redutores metálicos ativos, que capturam o oxigênio no interior das embalagens convertendo-se em óxidos mais estáveis (Vermeiren et al., 1999). 
Comercialmente, estão disponíveis em uma variedade de tamanhos capazes de absorver volumes compreendidos entre 20 e $2000 \mathrm{~mL}$ de oxigênio no espaço-livre, reduzindo os níveis de $\mathrm{O}_{2}$ a concentrações menores de $0,01 \%$ entre 1 e 4 dias, a temperatura ambiente. Existem absorvedores desenvolvidos especialmente para condições de estocagem sob temperaturas de congelamento ou refrigeração. Estes absorvedores são utilizados para aumentar a qualidade e a vida útil de alimentos com atividade de água superior a 0,85 , como as carnes frescas, e reagem mais rapidamente, entre 2-3 dias $\left(0-4^{\circ} \mathrm{C}\right)$ (Smith et. al., 1995).

Gill \& McGinnis (1995) observaram a necessidade de otimização das condições de acondicionamento para minimizar o número de absorvedores requeridos para prevenir a descoloração transitória da carne bovina sob atmosfera controlada, como por exemplo, assegurar temperaturas refrigeração $1{ }^{\circ} \mathrm{C}$, manter teores de oxigênio residual $<0,01 \%$, bem como reduzir o volume de atmosfera / peso $(\mathrm{kg})$ de produto. Estudos posteriores (Isdell et al., 1999 e Tewari et al., 1999) demonstraram o potencial de sistemas masterpack com atmosfera modificada e absorvedores de oxigênio prolongarem a vida de prateleira de bifes de carne bovina.

Em síntese, a aplicação comercial do sistema masterpack com atmosfera livre de oxigênio depende de estudos enfatizando os fatores que afetam a descoloração da carne, além de avaliações sensoriais de aceitabilidade dos bifes (Gill et al., 1994). Na prática, torna-se necessário evitar a oxidação dos pigmentos superficiais da carne pelo controle adicional do oxigênio residual no espaço-livre das embalagens masterpack e, assim retardar o crescimento de microrganismos potencialmente deteriorantes. 


\section{MATERIAIS E MÉTODOS}

\subsection{Testes Preliminares}

Antecedendo a realização do teste final para avaliar a vida útil e o potencial de reblooming dos produtos, foram realizados três testes preliminares para otimização do sistema de embalagem, ou seja, seleção da bandeja plástica, dos absorvedores de $\mathrm{O}_{2}$ e do filme primário.

Após a selagem do filme primário, quatro bandejas contendo bifes de alcatra e quatro bandejas com bifes de contra filé foram distribuídas em uma embalagem de transporte tipo masterpack (582 x $434 \mathrm{~mm})$ contendo um absorvedor de oxigênio baseado no princípio de oxidação do ferro. A taxa de permeabilidade da embalagem masterpack foi $19 \mathrm{~cm}^{3}(\mathrm{CNTP}) / \mathrm{m}^{2} / \mathrm{dia}$ a $25^{\circ} \mathrm{C}, 75 \% \mathrm{UR}$ e $1 \mathrm{~atm}$. A estrutura do filme coextrusado $\left(0,26 \mathrm{~m}^{2}\right.$ de área de permeação) apresentava uma camada de copolímero de etileno e álcool vinílico, que the conferiu a característica de barreira ao oxigênio e também ao gás carbônico. As embalagens do tratamento controle (sem absorvedores de oxigênio) foram preparadas da mesma maneira.

A taxa de permeabilidade do oxigênio nominal do filme Clysar AFG tipo AFG, $15 \mu \mathrm{m}$, da DuPont, perfurado a cada $4 \mathrm{~cm}$ na longitudinal e a cada 4 a $5 \mathrm{~cm}$ na transversal é de $20.000 \mathrm{~cm}^{3} /(\mathrm{CNTP}) / \mathrm{m}^{2} / \mathrm{dia}$ a $23^{\circ} \mathrm{C}$ e $1 \mathrm{~atm}$ e a do PVC esticável, $12 \mu \mathrm{m}$, é de 10.255 $\mathrm{cm}^{3} /(\mathrm{CNTP}) / \mathrm{m}^{2} /$ dia a $23^{\circ} \mathrm{C}$ e $1 \mathrm{~atm}$. Em ambos os casos, a área de permeação/bandeja foi de $433 \mathrm{~cm}^{2}$. A selagem e o termoencolhimento $\left(130-135^{\circ} \mathrm{C}\right)$ do filme Clysar foram feitos em uma seladora Selopack. Uma seladora de chapa aquecida Ipcal foi utilizada para o fechamento das embalagens envoltas com filme de PVC esticável. 
Ao final de cada período de armazenamento, foram abertas duas embalagens masterpack de cada sistema testado e retirados 4 conjuntos de bandejas para cada músculo, cada um composto por 2 bandejas acondicionadas com absorvedores de oxigênio e 2 acondicionadas sem absorvedores de oxigênio. $\mathrm{O}$ primeiro conjunto de bandejas foi utilizado para realização dos testes de $\mathrm{pH}$, o segundo para avaliação da cor objetiva, o terceiro para avaliação sensorial e o quarto conjunto foi utilizado para a execução das avaliações microbiológicas. Os testes preliminares também serviram para ajustamento do equipamento de acondicionamento em termos de nível de vácuo e do binômio tempo/pressão de $\mathrm{CO}_{2}$ em cada ciclo.

\subsubsection{Seleção do tipo de bandeja e absorvedor de oxigênio}

Os músculos de alcatra e contra filé acondicionados à vácuo foram adquiridos em um açougue da cidade de Campinas e foram preparados na forma de bifes de aproximadamente $10-15 \mathrm{~mm}$ de espessura. na planta piloto do CTC-ITAL. Durante o processamento dos bifes de alcatra alguns valores individuais de $\mathrm{pH}$ indicavam que parte do lote experimental apresentavam a condição DFD (dark, firm and dry) ou seja, foram provenientes de animais abatidos em condição de estresse, enquanto que os bifes de contra filé apresentaram sempre $\mathrm{pH}$ normal $(\mathrm{pH}<5,8)$. Foram preparados dois lotes experimentais envolvendo os dois músculos. Os bifes de alcatra e contra filé do primeiro lote experimental pesavam em média $0,353 \mathrm{~kg}$ e foram colocados sobre um absorvedor de líquido (DryLock, Cryovac) em uma bandeja branca de poliestireno expandido (isopor), modelo $3 \mathrm{RR}(23,8 \times 18,2 \times 1,9 \mathrm{~cm})$, cedidas pela Cryovac. Os bifes de alcatra e contra filé do segundo lote experimental (peso médio=0,426 kg) foram acondicionados sobre um absorvedor de líquido (DryLock, Cryovac) em uma bandeja de poliestireno não expandido transparente (cristal), modelo B1 $(22,3 \times 14,0 \times 3,0 \mathrm{~cm})$, cedidas pela Neoform.

As bandeja dos dois lotes experimentais foram envoltas em filme poliolefínico termoencolhível Clysar tipo AFG, $15 \mu \mathrm{m}$ (DuPont). A taxa de permeabilidade de oxigênio $\left(\mathrm{TPO}_{2}\right)$ do filme Clysar foi $20.000 \mathrm{~cm}^{3} /(\mathrm{CNTP}) / \mathrm{m}^{2} / \mathrm{dia}$ a $23^{\circ} \mathrm{C}$ e $1 \mathrm{~atm}$. 
Após a selagem do filme primário em seladora Selovac, 8 bandejas de poliestireno cristal, quatro contendo bifes de alcatra e quatro contendo bifes de contra filé, foram distribuídas em uma embalagem de transporte tipo masterpack (58,2 x 43,4 $\mathrm{cm}, 0,25 \mathrm{~m}^{2}$ de área de permeação). A estrutura do filme coextrusado da embalagem masterpack apresentava uma camada de copolímero de etileno e álcool vinílico, que lhe conferiu a característica de barreira ao oxigênio e também ao gás carbônico $\left(\mathrm{TPO}_{2}=\right.$ $19 \mathrm{~cm}^{3}(\mathrm{CNTP}) / \mathrm{m}^{2} / \mathrm{dia}$ a $25^{\circ} \mathrm{C}, 75 \% \mathrm{UR}$ e $\left.1 \mathrm{~atm}\right)$.

$\mathrm{Na}$ metade das embalagens deste primeiro lote foi adicionado um sachê absorvedor de oxigênio, com capacidade de seqüestrar $500 \mathrm{~cm}^{3}$ de oxigênio (O-Buster FT500, O-Buster, Taiwan), imediatamente antes da injeção de $\mathrm{CO}_{2}$ e da selagem da embalagem masterpack, enquanto que a outra metade foi armazenada sem absorvedor de oxigênio (tratamento controle).

As bandejas de poliestireno expandido do segundo lote experimental foram distribuídas nas embalagens de transporte da mesma maneira, com exceção do absorvedor de oxigênio adicionado, Ageless SS400 (Mitsubishi, Japão), que neste caso tinha capacidade de sequiestrar $400 \mathrm{~cm}^{3}$ de oxigênio. Todas as embalagens foram armazenadas em uma câmara refrigerada no escuro por até 14 dias a $1 \pm 1{ }^{\circ} \mathrm{C}$.

No dia do processamento dos bifes, duas bandejas de cada músculo serviram como controle da carne fresca e foram acondicionadas em balcão expositor refrigerado para avaliação visual e objetiva da cor e outras 2 bandejas de cada músculo foram caracterizadas microbiologicamente através da contagem de bactérias psicrotróficas aeróbias, psicrotróficas anaeróbias e mesófilos. Imediatamente após o preparo dos lotes experimentais e após 7 e 14 dias, foram avaliados os teores de oxigênio na atmosfera modificada em duas embalagens masterpack de cada um dos quatro sistemas de embalagens:

- PS cristal sem absorvedores (tratamento controle $\mathrm{C}_{1}$ )

- PS cristal com absorvedores O-BusterFT500

- PS expandido sem absorvedores (tratamento controle $\mathrm{C}_{2}$ )

- PS expandido com absorvedores Ageless SS400 
As avaliações sensoriais, objetivas, microbiológicas e de $\mathrm{pH}$ dos bifes de alcatra e contra filé de cada sistema de embalagem também foram realizadas em duplicata. Para avaliação sensorial da cor as bandejas foram colocadas em expositor refrigerado iluminado com luz incandescente à temperatura $4 \pm 2^{\circ} \mathrm{C}$. A cor vermelha foi avaliada visualmente por um painel treinado de 5 julgadores.

As avaliações sensoriais e objetivas da cor foram realizadas através do filme transparente de PVC que envolvia as bandejas, após 1h de exposição aeróbica, para permitir a re-oxigenação da mioglobina. $\mathrm{O}$ efeito do armazenamento sob $\mathrm{CO}_{2}$ sobre a cor objetiva dos bifes acondicionados nos diferentes sistemas de embalagens testados foi realizado através da análise de variância (ANOVA) e o teste de Scheffé foi realizado para comparação das médias dos sistemas. Efeitos estatísticamente significantes foram observados quando $\mathrm{p}<0,05 . \mathrm{O} \mathrm{pH}$ interno e externo dos bifes foi medido com um eletrodo de vidro (WTWpH91) colocado diretamente nos bifes. A amostragem para avaliação microbiológica foi realizada assepticamente, no fluxo laminar, através da coleta de $25 \mathrm{~g}$ do produto na porção superficial dos bifes que foram colocadas em $225 \mathrm{~mL}$ BPW (Água Peptonada Tamponada). As diluições decimais subseqüentes foram feitas em solução estéril peptonada. As placas inoculadas foram incubadas por $72 \mathrm{~h} \mathrm{a} 21^{\circ} \mathrm{C}$ para contagem das bactérias psicrotróficas aeróbias, por $72 \mathrm{~h}$ a $21^{\circ} \mathrm{C}$ em jarro de anaerobiose para contagem das psicrotróficas anaeróbias e por $48 \mathrm{~h}$ a $35^{\circ} \mathrm{C}$ para contagem de mesófilos. Após 14 dias de armazenamento sob $\mathrm{CO}_{2}$ a análise de psicrotróficos aeróbios foi repetida. Todas as análises foram realizadas utilizando-se as metodologias descritas por Vanderzant \& Splittstoesser (1992).

\subsubsection{Efeito do tipo de absorvedor de oxigênio}

Os músculos de alcatra obtidos de animais abatidos em escala piloto no Centro de Tecnologia de Carnes - ITAL, provenientes do processo FAPESP 2000/06438-8 foram acondicionadas a vácuo sob temperatura de refrigeração de $1 \pm 1^{\circ} \mathrm{C}$ por 4 dias antes do processamento dos bifes e acondicionamento em atmosfera modificada. Porções de peso médio de $0,386 \mathrm{~kg}$ de alcatra em bifes, com aproximadamente $1,0-1,5 \mathrm{~cm}$ de 
espessura, cortados a partir de peças inteiras, foram acondicionados sobre um absorvedor de líquido em bandejas de poliestireno expandido, envoltas em filme poliolefínico termoencolhível Clysar. Duas bandejas serviram como controle da carne fresca e foram acondicionadas em balcão expositor refrigerado para avaliação visual e objetiva da cor e outras duas bandejas foram caracterizadas microbiologicamente através da contagem de bactérias psicrotróficas aeróbias, psicrotróficas anaeróbias e mesófilos. Um conjunto de 8 bandejas foi colocado em cada embalagem de transporte tipo masterpack. Os três diferentes sistemas de embalagens processados são descritos a seguir:

- embalagens masterpack controle, ou seja, sem absorvedor de oxigênio, com 8 bandejas com bifes de alcatra em cada saco;

- embalagens masterpack contendo dois sachês absorvedores de oxigênio tipo ATCO HV210 contendo 8 bandejas com bifes de alcatra em cada saco;

- embalagens masterpack com um sachê absorvedor de oxigênio tipo O-Buster FT300, contendo 8 bandejas com bifes de alcatra, em cada saco.

Imediatamente após a selagem das embalagens masterpack foi realizada a avaliação da composição gasosa no interior das embalagens, e em seguida os produtos foram armazenados por até 14 dias em câmara fria a $4 \pm 1^{\circ} \mathrm{C}$.

Após 7 e 14 dias, foram reavaliados os teores de oxigênio na atmosfera modificada em duas embalagens masterpack de cada um dos quatro sistemas de embalagens (PS cristal com absorvedores O-BusterFT500, PS cristal sem absorvedores, PS expandido com absorvedores Ageless SS400 e PS expandido sem absorvedores), imediatamente antes da sua abertura. Os resultados da composição gasosa foram expressos em porcentagem de volume de $\mathrm{O}_{2}$. As avaliações sensoriais, objetivas e de $\mathrm{pH}$ dos bifes de alcatra de cada sistema de embalagem também foram realizadas em duplicata. As avaliações sensoriais e objetivas da cor foram realizadas através do filme transparente de PVC que envolvia as bandejas, após $1 \mathrm{~h}$ de exposição aeróbica, para permitir a re-oxigenação da mioglobina. Para avaliação sensorial da cor vermelha, as bandejas foram colocadas em expositor refrigerado iluminado com luz incandescente à 
temperatura $422^{\circ} \mathrm{C}$. A cor vermelha foi avaliada visualmente por um painel treinado de 5 julgadores.

$\mathrm{O}$ efeito do armazenamento sob $\mathrm{CO}_{2}$ sobre a cor objetiva dos bifes acondicionados nos diferentes sistemas de embalagens testados foi realizado através da análise de variância (ANOVA) e o teste de Scheffé foi realizado para comparação das médias dos sistemas. Efeitos estatísticamente significantes foram observados quando $\mathrm{p}<0,05$. O pH interno e externo dos bifes foi medido com um eletrodo de vidro (WTWpH91) colocado diretamente nos bifes. A amostragem para avaliação microbiológica foi realizada assepticamente, no fluxo laminar, através da coleta de $25 \mathrm{~g}$ do produto na porção superficial dos bifes que foram colocadas em $225 \mathrm{~mL}$ BPW (Água Peptonada Tamponada). As diluições decimais subseqüentes foram feitas em solução estéril peptonada. As placas inoculadas foram incubadas por $72 \mathrm{~h}$ a $21^{\circ} \mathrm{C}$ para contagem das bactérias psicrotróficas aeróbias, por $72 \mathrm{~h}$ a $21^{\circ} \mathrm{C}$ em jarro de anaerobiose para contagem das psicrotróficas anaeróbias e por $48 \mathrm{~h}$ a $35^{\circ} \mathrm{C}$ para contagem de mesófilos. Após 14 dias de armazenamento sob $\mathrm{CO}_{2}$ a análise de psicrotróficos aeróbios foi repetida. Todas as análises foram realizadas utilizando-se as metodologias descritas por Vanderzant \& Splittstoesser (1992).

\subsubsection{Efeito do tipo de filme primário}

Os músculos de contra-filé e alcatra foram provenientes do frigorífico FriBoi. As peças inteiras embaladas à vácuo foram transportados em caminhões climatizados. O processamento ocorreu na planta piloto do Centro de Tecnologia de Carnes CTC/ITAL, Campinas, onde foram abertas as embalagens e fatiados os bifes, para serem colocados em bandejas.

Porções de peso médio de $380 \mathrm{~g}$ de alcatra e contra filé em bifes, com aproximadamente 1,0-1,5 $\mathrm{cm}$ de espessura, foram acondicionados em uma embalagem primária, composta de bandejas de poliestireno expandido, sendo que metade das amostras, foram envoltas em filme poliolefínico termoencolhível Clysar e o restante das bandejas foram envoltas em filme de PVC esticável, $12 \mu \mathrm{m}$. Duas bandejas de cada 
músculo serviram como controle da carne fresca e foram acondicionadas em balcão expositor refrigerado para avaliação visual e objetiva da cor e outras 2 bandejas de cada músculo foram caracterizadas microbiologicamente através da contagem de coliformes totais e fecais, Salmonela, Clostridium sulfito redutor, mesófilos, psicrotróficos aeróbios, psicrotróficos anaeróbios, Staphylococcus aureus, bactérias láticas.

Um conjunto de 4 bandejas com bifes de alcatra e 4 bandejas com bifes de contra filé, embaladas com um mesmo tipo de filme, foi colocado em posição alternada (alcatra/contra filé) na embalagem de transporte masterpack. Em parte dos sacos foi adicionado um absorvedor de oxigênio ATCO HV1000 sobre as bandejas, sem contato com a carne. Embalagens masterpack sem absorvedor de oxigênio foram tidos como controle. Todas as embalagens foram armazenadas em uma câmara refrigerada no escuro por até 42 dias a $1 \pm 1^{\circ} \mathrm{C}$.

Foram avaliados os teores de oxigênio na atmosfera modificada em duas embalagens masterpack por tratamento (com absorvedores ATCO HV1000 e controle), imediatamente após o preparo do lote experimental e imediatamente antes da abertura das embalagens masterpack, após cada período de armazenamento avaliado (7, 14, 21 e 28 dias). Avaliações sensoriais e objetivas da cor foram realizadas através do filme transparente de PVC após 1, 24 and 48h de exposição aeróbica. O pH interno e externo dos bifes foi medido com um eletrodo de vidro (WTWpH91) colocado diretamente nos bifes. As avaliações sensoriais, objetivas, microbiológicas e de $\mathrm{pH}$ dos bifes de alcatra e contra filé de cada lote foram realizadas em duplicata. Para avaliação sensorial da cor as bandejas foram colocadas em expositor refrigerado iluminado com luz incandescente à temperatura $4 \pm 2^{\circ} \mathrm{C}$ for $48 \mathrm{~h}$. A cor vermelha foi avaliada visualmente por um painel treinado de 10 julgadores.

A avaliação do efeito do armazenamento sob $\mathrm{CO}_{2}$ sobre a cor vermelha sensorial e objetiva dos diferentes sistemas de embalagens testados foi realizado através da análise de variância (ANOVA) para comparação das médias dos sistemas. Efeitos estatisticamente significantes foram observados quando $\mathrm{p}<0,05$.

Em todos os testes preliminares citados acima, a modificação da atmosfera nas embalagens tipo masterpack foi feita em máquina CVP, modelo A-300, com 2 bicos 
retráteis, operando com 2 ciclos de vácuo (V) e injeção de gás (G) (VGVG: V1=8; G1=6; V2=7; G2=5, selagem H.S.=5,0 e H.S. cool=5,0) com injeção de atmosfera a 4,5 $\mathrm{kgf} / \mathrm{m}^{2}$ de pressão de $\mathrm{CO}_{2}$ puro $\left(\mathrm{O}_{2}<10 \mathrm{ppm}\right)$, em uma razão aproximada de 2,5 a $3,0 \mathrm{~L}$ gás/kg de carne.

\subsection{Teste Final}

Foram preparados dois lotes experimentais envolvendo dois tipos de músculos, com diferentes susceptibilidades à oxidação da mioglobina: o contra filé (longissimus dorsi) que apresenta maior estabilidade de cor e o alcatra (Gluteus medius) de baixa estabilidade. Os músculos do primeiro lote estavam acondicionados à vácuo (Frigorífico Independência - Cajamar), enquanto que os do segundo lote (Frigorífico Angileli Piracicaba) estavam envoltos em filme de polietileno de baixa densidade.

Os músculos foram preparados na forma de bifes de aproximadamente 10-15mm de espessura. na planta piloto do CTC-ITAL. Durante o processamento dos bifes de contra filé alguns valores individuais de $\mathrm{pH}$ indicavam que parte do lote experimental do Frigorífico Independência apresentava a condição DFD (dark, firm and dry) ou seja, foram provenientes de animais abatidos em condição de estresse, enquanto que os bifes de alcatra apresentaram sempre $\mathrm{pH}$ normal $(\mathrm{pH}<5,8)$, independente do frigorífico. Porções de dois bifes $(0,386 \pm 0,045 \mathrm{~kg})$ foram colocadas sobre um absorvedor de líquido (DryLock, Cryovac) em uma bandeja branca de poliestireno expandido com dimensões de 238 x 182 x $190 \mathrm{~mm}$. Cada bandeja foi envolvida por um filme termoencolhível esticável transparente de PVC com $12 \mu \mathrm{m}$ de espessura e taxa de permeabilidade ao oxigênio de cerca de $12.232 \mathrm{~cm}^{3} / \mathrm{m}^{2} / 24 \mathrm{~h} / \mathrm{atm}$ a $25^{\circ} \mathrm{C}$ e $75 \%$ U.R. Após a selagem do filme, quatro bandejas contendo bifes de alcatra e quarto bandejas com bifes de contra filé foram distribuídas em uma embalagem de transporte tipo masterpack (582 x 434 $\mathrm{mm}$ ) contendo um sachê absorvedor de oxigênio (ATCO HV1000) baseado no princípio de oxidação do ferro. $19 \mathrm{~cm}^{3}(\mathrm{CNTP}) / \mathrm{m}^{2} /$ dia $25^{\circ} \mathrm{C}, 75 \% \mathrm{UR}$ e $1 \mathrm{~atm}$. A estrutura do filme coextrusado $\left(0,26 \mathrm{~m}^{2}\right.$ de área de permeação) apresentava uma camada de copolímero de 
etileno e álcool vinílico, que the conferiu a característica de barreira ao oxigênio e também ao gás carbônico.

A modificação da atmosfera nas embalagens tipo masterpack foi feita em máquina CVP, modelo A300, com 2 bicos retráteis, operando com 2 ciclos de vácuo e injeção de atmosfera a $3,5 \mathrm{kgf} / \mathrm{cm}^{2}$ de pressão de $\mathrm{CO}_{2}$ puro $\left(\mathrm{O}_{2}<10 \mathrm{ppm}\right)$, em uma razão aproximada de 2,5 a 3,0L gás $/ \mathrm{kg}$ de carne. As embalagens do tratamento controle (sem absorvedores de oxigênio) foram preparadas da mesma maneira. Todas as embalagens foram armazenadas em uma câmara refrigerada no escuro por até 42 dias a $41^{\circ} \mathrm{C}$. No dia do processamento dos bifes, duas bandejas de cada músculo serviram como controle da carne fresca e foram acondicionadas em balcão expositor refrigerado para avaliação visual e objetiva da cor e outras 2 bandejas de cada músculo foram caracterizadas microbiologicamente através da contagem de coliformes totais e fecais, Salmonela, Clostridium sulfito redutor, mesófilos, psicrotróficos aeróbios, psicrotróficos anaeróbios, Staphylococcus aureus, bactérias láticas. Foram avaliados os teores de oxigênio na atmosfera modificada em duas embalagens masterpack por tratamento (com absorvedores ATCO HV1000 e controle), imediatamente após o preparo do lote experimental e imediatamente antes da abertura das embalagens masterpack, após cada período de armazenamento avaliado. Após a análise do gás 4 embalagens masterpacks de cada lote experimental (duas contendo absorvedores de oxigênio e duas sem absorvedores) foram abertas em intervalos de 14, 28, 35 e 42 dias. As avaliações sensoriais, objetivas, microbiológicas e de $\mathrm{pH}$ dos bifes de alcatra e contra filé de cada lote foram realizadas em duplicata. Avaliações sensoriais e objetivas da cor foram realizadas através do filme transparente de PVC após 1, 24 and 48h de exposição aeróbica. $\mathrm{O}$ pH interno e externo dos bifes foi medido com um eletrodo de vidro (WTWpH91) colocado diretamente nos bifes. Para avaliação sensorial da cor as bandejas foram colocadas em expositor refrigerado iluminado com luz incandescente à temperatura $4 \pm 2^{\circ} \mathrm{C}$ for $48 \mathrm{~h}$. A cor vermelha foi avaliada visualmente por um painel treinado de 10 julgadores.

A avaliação dos dados sobre o efeito do armazenamento sob $\mathrm{CO}_{2}$ nos diferentes sistemas de embalagens testados foi realizado através da análise de variância (ANOVA) 
para comparação das médias dos sistemas. Efeitos estatísticamente significantes foram observados quando $\mathrm{p}<0,05$.

Após 42 dias de armazenamento sob $\mathrm{CO}_{2}$ foi realizado um teste de aceitação com 80 consumidores, num supermercado localizado na cidade de Campinas. As amostras de alcatra e contra filé acondicionadas com absorvedores de oxigênio foram apresentadas em duplicata para cada consumidor que foi convidado a expressar sua intenção de compra através de uma escala de categoria que variava de certamente compraria até certamente não compraria, além de indicar quais os fatores que o levariam a aceitar ou rejeitar cada produto.

\subsection{Descrição dos métodos utilizados para avaliação da vida útil}

\subsubsection{Avaliação do oxigênio residual nas embalagens tipo masterpack}

Foram avaliados os teores de oxigênio e de gás carbônico na atmosfera modificada em duas embalagens masterpack por tratamento, imediatamente após o preparo do lote experimental e imediatamente antes da abertura das embalagens masterpack, após cada período de armazenamento avaliado, em analisador de gás PBI Dansensor, através de um septo colado na embalagem. Os resultados da composição gasosa foram expressos em porcentagem de volume de $\mathrm{O}_{2}$.

\subsection{2 pH}

Durante o processamento foram medidos os valores de $\mathrm{pH}$ interno e/ou externo das porções caudal e cranial dos músculos de alcatra e contra filé para avaliação da matéria-prima. Após cada período de armazenamento sob $\mathrm{CO}_{2}$, o $\mathrm{pH}$ interno e/ou externo dos bifes de alcatra e contra filé foram medidos com um eletrodo de vidro colocado diretamente sobre os bifes. 


\subsubsection{Avaliação microbiológica}

Para caracterização da matéria-prima, foram realizadas análises de E.coli, coliformes totais, contagem total de bactérias mesófilas, psicrotróficas aeróbias e anaeróbias e láticas, $S$ aureus, Salmonella sp. e Clostridium sulfito redutor dos músculos de alcatra e contra filé, através da coleta, em duplicata, de 25 gramas de cada músculo, retirados aleatoriamente da superfície das peças, logo após a abertura dos filmes primários que as envolviam.

As amostras (25g cada) foram removidas com uma lâmina estéril e homogeneizadas com $225 \mathrm{~mL}$ de água salina peptonada.

Todas as análises foram realizadas de acordo com a metodologia de Vanderzant \& Splittstoesser (1992).

Após cada período de armazenamento foram repetidas, em duplicata, as contagens, psicrotróficos aeróbios, psicrotróficos anaeróbios e bactérias láticas das amostras de alcatra e contra filé acondicionados com absorvedores de oxigênio, bem como das amostras do tratamento controle (sem absorvedores).

Nos dois primeiros testes preliminares, apenas foram realizadas as contagens de mesófilos aeróbios, psicrotróficos aeróbios e anaeróbios, para a caracterização da matéria-prima e, após cada período de armazenamento foram repetidas somente as análises de psicrotróficos aeróbios e anaeróbios.

\subsubsection{Avaliação sensorial da cor}

Os dois primeiros testes preliminares serviram para treinar um grupo formado por 12 estudantes e pesquisadores recrutados no Centro de Tecnologia de Carnes do ITAL. O critério para seleção foi motivação e disponibilidade para participar de todo o experimento. Durante as sessões, a equipe sensorial formada por 12 membros, verbalizava as sensações e impressões, discutindo e listando os atributos que caracterizavam o produto, estabelecendo os termos mais utilizados, bem como os extremos e a intensidade das escalas de cor sensorial. 
A seleção da equipe foi feita entre os estagiários, funcionários e pesquisadores do Centro de Tecnologia de Carnes do Instituto de Tecnologia de Alimentos, tendo 30\% de homens e $70 \%$ de mulheres, com idades entre 20 e 50 anos, sendo dispensadas as pessoas com envolvimento direto no projeto, as que prepararam as amostras, bem como aquelas que apresentaram aversão ao produto ou não tinham o hábito de consumi-lo. Ao final do treinamento foram selecionados 10 julgadores, estes eram os que apresentavam melhor reprodutibilidade dos resultados.

Os julgadores selecionados, apresentaram durante o treinamento boa reprodutibilidade de resultados, acuidade visual, habilidade verbal, capacidade de trabalho em grupo, cooperação, motivação e prontidão.

As análises do último teste preliminar e do teste final, com o sistema de embalagem otimizado, foram realizadas em uma área isolada, onde as amostras ficaram acondicionadas em um expositor refrigerado à temperatura de $4 \pm 2^{\circ} \mathrm{C}$, sob iluminação fluorescente branca, com intensidade de iluminação na faixa de 442 a 335lux. Durante a análise as bandejas eram retiradas do expositor a apresentadas de forma monádica a cada julgador.

As avaliações sensoriais da intensidade da cor do músculo (vermelha, roxa e marrom) e da cor da gordura (rosa e cinza) foram realizadas utilizando escalas não estruturadas de $10 \mathrm{~cm}$, onde os extremos variavam de pouco $(0 \mathrm{~cm})$ a intenso $(10 \mathrm{~cm})$ e escalas de categoria para aparência e porcentagem de manchas no músculo.

As escalas para avaliação de cor do músculo e da gordura (Figura 2) foram desenvolvidas com auxílio das paletas removíveis de cor do Livro de cor Munsell, que foram adotadas em alguns pontos âncoras das escalas lineares não estruturadas de 10 cm:

Cor vermelha do músculo: $3 \mathrm{~cm}=7.5 \mathrm{R} 5 / 10 ; 5 \mathrm{~cm}=7.5 \mathrm{R} 4 / 10 ; 7 \mathrm{~cm}=10 \mathrm{R} 3 / 6$.

Cor marrom do músculo: $8 \mathrm{~cm}=10 \mathrm{R} 3 / 2 ; 10 \mathrm{~cm}=7.5$ YR 2/4

Cor roxa do músculo: $5 \mathrm{~cm}=2.5 \mathrm{R} 3 / 8,10 \mathrm{~cm}=7.5 \mathrm{YR} 3 / 4$

Cor rosa da gordura: $9 \mathrm{~cm}=10 \mathrm{R} 8 / 6$.

Cor cinza da gordura: $6 \mathrm{~cm}=2.5 \mathrm{Y} 8 / 2$ 
A proporção de manchas na coloração do músculo foi avaliada em uma escala de 6 pontos, onde: $0=$ sem manchas, $1=$ até $5 \%, 2=5-15 \%, 3=15-25 \%, 4=25-35 \%$, e $5=$ mais de $35 \%$.

A aparência dos bifes foi avaliada com base em uma escala de categoria, vertical, mista de 7 pontos: $1=$ muito ruim; $2=$ ruim; $3=$ regular; $5=$ bom; $6=$ muito bom e $7=$ excelente. 


\section{Avaliacão Sensorial de Carne Bovina}

Por favor observe os bifes de carne bovina e responda as questões sobre a aparência do mesmo:

\section{Cor vermelha do músculo}

Vermelho

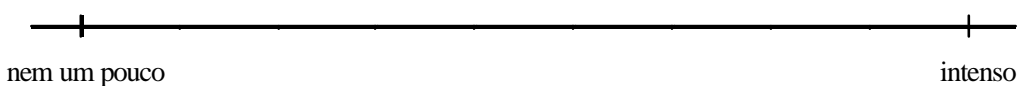

Roxo

$\begin{array}{lr}\text { nem um pouco } & \text { intenso }\end{array}$

Marrom

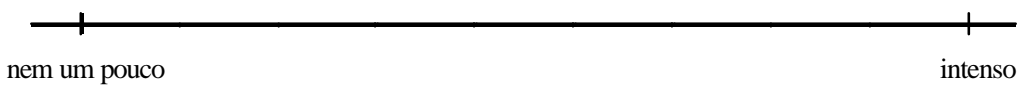

2. \% de descoloração no músculo (\% da mancha em relação a superfície do músculo):
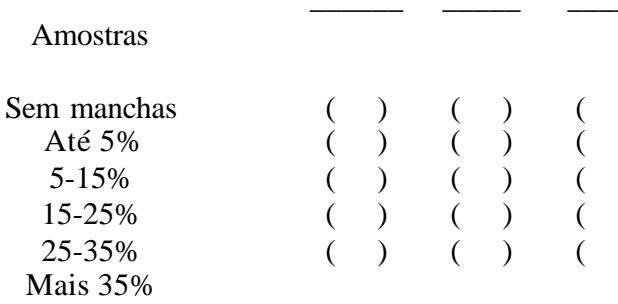

Mais $35 \%$

\section{Cor da gordura}

Rosa

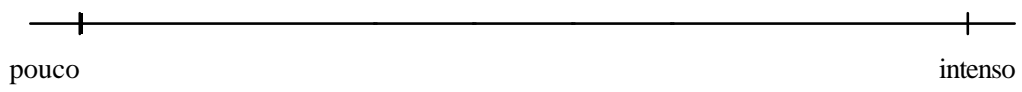

Cinza

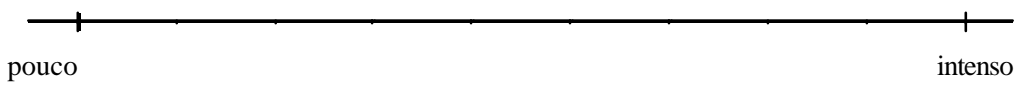

\section{Aparência}

$$
\begin{gathered}
\text { Amostras } \\
7 \text { - excelente } \\
6 \text { - muito bom } \\
5 \text { - bom } \\
4 \text { - nem bom nem regular } \\
3 \text { - regular } \\
2 \text { - ruim } \\
1 \text { - muito ruim }
\end{gathered}
$$

\begin{tabular}{|c|c|c|c|c|c|}
\hline ( & ) & ( & ) & ( & ) \\
\hline( & ) & ( & ) & ( & ) \\
\hline ( & ) & ( & ) & ( & ) \\
\hline( & ) & ( & ) & ( & ) \\
\hline( & ) & ( & ) & ( & ) \\
\hline ( & ) & ( & ) & ( & ) \\
\hline ( & ) & ( & ) & ( & ) \\
\hline
\end{tabular}

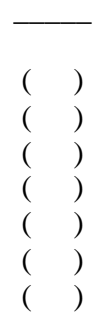

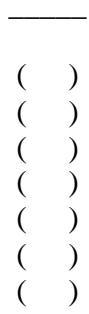
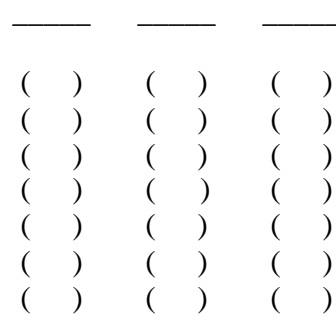

Comentários

Figura 2 - Ficha sensorial aplicada aos julgadores treinados no teste preliminar para a escolha do tipo de filme primário. 


\section{Teste final com o melhor sistema de embalagem}

As escalas para avaliação de cor do músculo e da gordura foram desenvolvidas com auxílio das paletas removíveis de cor do Livro de cor Munsell, que foram adotadas em alguns pontos âncoras das escalas lineares não estruturadas de 0 a 10 pontos:

Cor vermelha do músculo: valor $1=7.5 \mathrm{R} 5 / 10$; valor $5.5=8.75 \mathrm{R} 4 / 12$ e valor $10=10 \mathrm{R}$ $3 / 8$.

Cor marrom do músculo: valor $1=10 \mathrm{R} 3 / 6$; valor $10=5 \mathrm{YR} 3 / 4$

Cor roxa do músculo: valor $5=2.5 \mathrm{R} 3 / 8$, valor $10=7.5 \mathrm{YR} 3 / 4$

Cor rosa da gordura: valor $2=5 \mathrm{YR} 9 / 2$, valor $6=2.5 \mathrm{YR} 8 / 4$ e valor $10=2.5 \mathrm{YR} 5 / 6$.

Cor cinza da gordura: valor $2=5 \mathrm{Y} 8 / 1$ valor $6=2.5 \mathrm{Y} 8 / 2$ e valor $10=2.5 \mathrm{Y} 7 / 2$.

Conforme podemos observar na Figura 3 a cor do músculo e a cor rosa da gordura foram determinadas utilizando uma escala não estruturada de $10,00 \mathrm{~cm}$, onde $0,00 \mathrm{~cm}$ correspondia a pouca cor e $10,00 \mathrm{~cm}$ a cor intensa. A cor vermelha brilhante, típica de carne fresca foi representada por uma paleta colorida removível do livro de Munsell (8.75R 4/12) posicionada a 5,50cm da escala de vermelho, enquanto que a cor vermelha escura $(10 \mathrm{R} 3 / 8)$ foi ancorada no extremo direito da mesma escala $(10,00 \mathrm{~cm})$.

A porcentagem de mancha foi avaliada através de uma escala vertical de categoria de 4 pontos, onde: $0=$ sem manchas, $1=$ até $5 \%, 2=5-15 \%, 3=15-25 \%, 4$ $=$ mais de $25 \%$ e a aparência geral dos bifes foi avaliada com base em uma escala de categoria vertical mista de 7 pontos onde: $1=$ muito ruim; $2=$ ruim; $3=$ regular; $4=$ nem bom, nem regular; 5= bom; 6=muito bom e 7=excelente. As modificações no posicionamento da paleta de cor vermelha brilhante na escala de vermelho e da escala de porcentagem de manchas foram baseadas nos testes preliminares com a equipe treinada, que indicaram que estas alterações seriam relevantes para melhorar as avaliações. 


\section{Avaliação Sensorial de Carne Bovina}

Por favor observe os bifes de carne bovina e responda as questões sobre a aparência do mesmo:

\section{Cor vermelha do músculo}

Vermelho

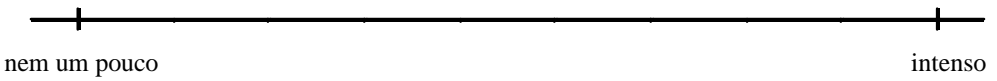

Roxo

$\underset{\text { nem um pouco }}{\text { intenso }}$

Marrom

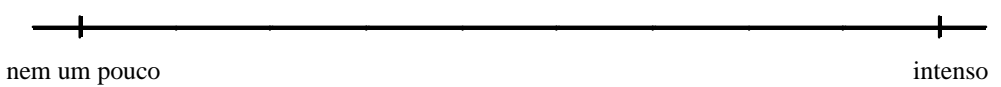

2. \% de descoloração no músculo (\% da mancha em relação a superfície do músculo):

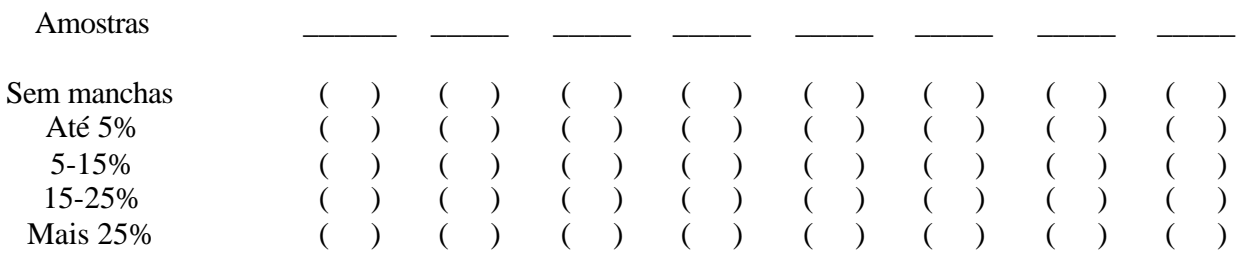

\section{Cor da gordura}

Rosa

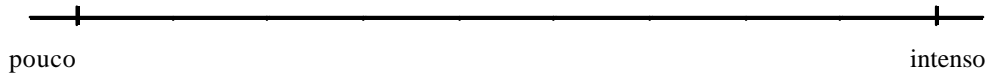

Cinza

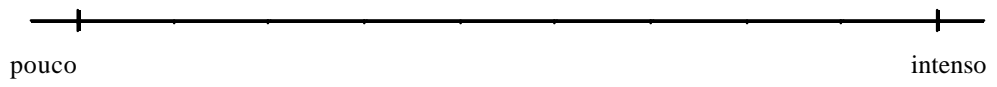

\section{Aparência}

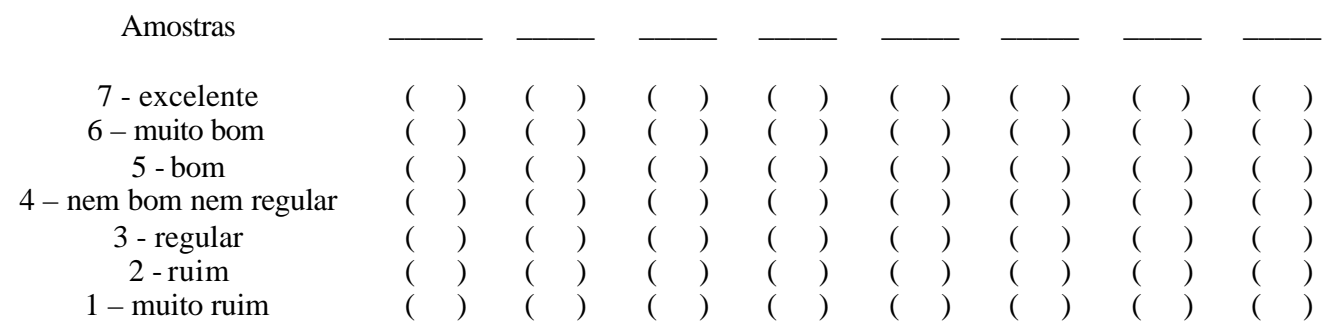

Comentários

Figura 3 - Ficha sensorial aplicada aos julgadores treinados no teste final. 


\section{Teste do Consumidor}

A aplicação do teste de aceitação ao consumidor (Figura 4) foi feita utilizando 80 consumidores em dois estabelecimentos comercias da cidade de Campinas, após 35 e 42 dias de armazenamento sob $\mathrm{CO}_{2}$. A cada consumidor eram apresentadas dezesseis bandejas sendo oito do corte de alcatra e oito de contra filé, que foram armazenadas sob atmosfera modificada e absorvedores de oxigênio.

O teste ocorreu após $1 \mathrm{~h}$ da abertura da embalagem de transporte (masterpack), para exposição aeróbica para permitir que a mioglobina combine-se com o oxigênio, formando a oximioglobina de coloração vermelho-brilhante, sinônimo de frescor e qualidade para o consumidor. Aos consumidores era pedido que indicasse o conjunto de bandejas, as quais ele poderia classificar de certamente compraria até certamente não compraria, além de indicar quais os fatores que o levariam a aceitar ou rejeitar cada tratamento. 


\section{Teste de aceitacão de carne bovina em bifes}

\section{1- Faixa Etária}

( ) menos de $20 \operatorname{anos}$ ( ) de 21 a 40 ( ) de 41 a 60 anos ( ) acima de 60 anos

2- Sexo: Feminino ( ) Masculino ( )

3- Ocupação: (por ex.:dona-de-casa,comerciário, etc)

4- Grau de instrução do chefe de família

\begin{tabular}{|l|l|}
\hline \multicolumn{1}{|c|}{ Analfabeto / primário incompleto } & \\
\hline Primário completo / Ginasial incompleto & \\
\hline Ginasial completo / colegial incompleto & \\
\hline Colegial completo / Superior incompleto & \\
\hline Superior completo & \\
\hline
\end{tabular}

5- Com que freqüência você consome carne?

( ) mais de 1 vez por semana ( ) até 1 vez por semana ( ) até 1 vez por mês ( ) de vez em quando

5- Qualidade global do produto

\begin{tabular}{|l|l|l|l|l|}
\hline \multicolumn{1}{|c|}{ Amostras } & & & & \\
\hline 06 - excelente & & & & \\
\hline $05-$ muito bom & & & & \\
\hline $04-$ bom & & & & \\
\hline $03-$ regular & & & & \\
\hline $02-$ ruim & & & & \\
\hline $01-$ muito ruim & & & & \\
\hline
\end{tabular}

Comentários:

7 - Descreva o que você mais gostou ou menos gostou de um MODO GERAL em cada amostra:

\begin{tabular}{|c|c|c|}
\hline Amostras & Mais gostou & Menos gostou \\
\hline & & \\
\hline & & \\
\hline & & \\
\hline & & \\
\hline
\end{tabular}

8- Se este produto estivesse à venda e o preço não fosse problema, você:

\begin{tabular}{|c|l|l|l|l|}
\hline Amostras & & & & \\
\hline Certamente compraria & & & & \\
\hline Provavelmente compraria & & & & \\
\hline Talvez comprasse talvez não & & & & \\
\hline Provavelmente não compraria & & & & \\
\hline Certamente não compraria & & & & \\
\hline
\end{tabular}

Figura 4 - Ficha sensorial aplicada no teste de aceitação. 


\subsubsection{Avaliação instrumental da cor}

Nos testes preliminares a cor superficial dos bifes foi observada através do filme primário, após $1 \mathrm{~h}$ de exposição aeróbica $\left(4 \pm 1^{\circ} \mathrm{C}\right)$, utilizando um espectrofotômetro manual (Minolta CR508d), a cor dos músculos foi expressa com bases coordenadas de luminosidade $\left(\mathrm{L}^{*}\right)$ e vermelho $\left(\mathrm{a}^{*}\right)$ do sistema CIELAB. Os valores de $\mathrm{L}^{*}, \mathrm{a}^{*}$ foram obtidos a cada período de exposição aeróbica. Foram tomadas 8 leituras por bife e 2 bandejas por tratamento e para cada tipo de músculo. O iluminante foi $\mathrm{C}$, o ângulo de observação foi de $2^{\circ}$ e o componente especular foi incluído.

No teste final a cor objetiva foi avaliada através das coordenadas de luminosidade $\left(\mathrm{L}^{*}\right)$, vermelho $\left(\mathrm{a}^{*}\right)$ e as variações de cor ao longo do tempo foram monitoradas pelo método simplificado de diferença de reflectância R6630-R580 (Strange et. al., 1974) obtidas através de um espectrofotômetro portátil (CM508d, Minolta, Japão). A média das oito leituras realizadas em cada bife foram gravadas em um banco de dados (Spectra Magic, Minolta, Japão) acoplado ao espectrofotômetro. O iluminante foi D65, o ângulo de observação foi $10^{\circ}$ e o componente especular foi excluído.

\subsubsection{Análises estatísticas}

A avaliação dos diferentes sistemas de embalagens testados foi realizado através da análise de variância (ANOVA) e testes de Scheffè para comparação das médias entre os tratamentos e seus respectivos controles. Efeitos estatisticamente significantes foram observados quando $\mathrm{p}<0,05$. 


\section{RESULTADOS E DISCUSSÃO}

\subsection{Efeito do tipo de bandeja plástica $x$ absorvedor de oxigênio}

\subsubsection{Avaliação do oxigênio residual das embalagens masterpack}

Os resultados da Figura 5 mostram que houve um aumento da concentração de oxigênio nos primeiros dias de armazenamento, independente do uso de absorvedores de oxigênio.

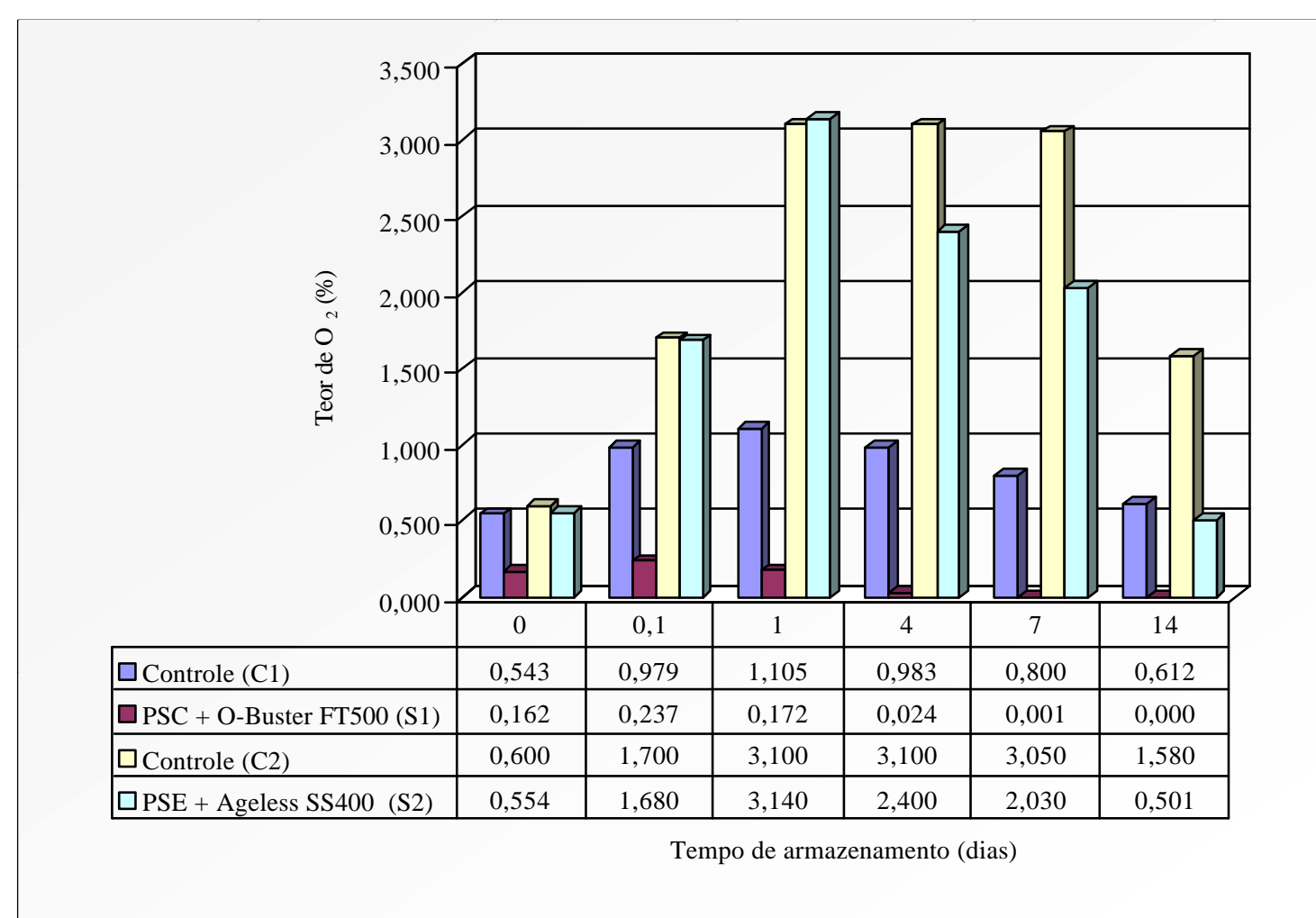

Figura 5 - Teor de oxigênio (\%) nas embalagens masterpack em função do tipo de bandeja. 
Segundo Tewari et. al. (2001), esse aumento é inevitável, inicialmente, devido à dissolução de oxigênio ocluso no absorvedor de líquido, sob o filme primário ou entre os bifes. Tewari et al. (2001) também observam que, inicialmente, o tecido superficial da carne libera $\mathrm{O}_{2}$ livre, devido à redução da oximioglobina à deoximioglobina que ocorre em baixa pressão parcial de oxigênio.

Gill (1996) observou que a oxidação irreveresível da mioglobina pode ser prevenida se concentrações residuais de $\mathrm{O}_{2}$ atingir teores inferiores a $0,001 \% \mathrm{em}$, no máximo, uma hora após o fechamento das embalagens.

Tewari et. al. (2001) examinaram o desempenho de vários absorvedores de oxigênio disponíveis comercialmente e concluíram que capacidade nominal de absorção é mais importante para a prevenção da descoloração que o tipo de absorvedor utilizado.

Conforme pode ser observado na Figura 5, as embalagens masterpack que continham absorvedores de oxigênio, O-Buster FT500 ou Ageless SS400, apresentaram teores residuais de $\mathrm{O}_{2}$ inferiores às embalagens dos tratamentos controle $(\mathrm{C} 1$ e $\mathrm{C} 2)$.

O sistema de embalagens que utilizou bandejas transparentes de poliestireno cristal (PSC) associado a absorvedores de oxigênio O-Buster FT500 favoreceu o desenvolvimento do reblooming em aproximadamente 40-95\% dos bifes de alcatra e de 20-70\% da superfície dos bifes contra filé, após 1 semana de armazenamento sob $\mathrm{CO}_{2}$. Após 14 dias de armazenamento sob $\mathrm{CO}_{2}$ essas frações aumentaram e então, aproximadamente, $85-95 \%$ da superfície dos bifes de alcatra e de contra filé readquiriram coloração vermelho cereja típica de carne fresca.

Os bifes de alcatra e contra filé acondicionados em bandejas de poliestireno expandido (PSE), popularmente conhecido como isopor, não readquiriram coloração vermelha após exposição ao ar, em nenhum dos períodos avaliados, a despeito do uso de absorvedores.

Comparativamente, as embalagens masterpack que acondicionavam as bandejas de isopor, apresentaram teores residuais de oxigênio superiores às embalagens masterpack que acondicionavam bandejas de PSC. 
$\mathrm{O}$ ar ocluso na estrutura celular formada durante a durante a fabricação da bandeja de isopor aumentou a concentração de oxigênio das embalagens masterpack que as continham, favorecendo a descoloração.

Segundo Gill \& Jones (1995) os bifes acondicionados sob $\mathrm{CO}_{2}$ ou $\mathrm{N}_{2}$ podem

apresentar-se com coloração amarronzada, após exposição aeróbica, por um curto intervalo de tempo, somente se o oxigênio residual não for excessivo. Isso ocorre porque o oxigênio residual presente nas embalagens masterpack é seqüestrado pela carne, com a formação de metamioglobina na superfície dos bifes. No entanto, decorridos alguns dias, a metamioglobina formada pode ser revertida à mioglobina pela atividade enzimática do músculo, permitindo o desenvolvimento da cor vermelha da carne exposta ao ar (reblooming).

Esse "atraso" para a reaquisição da cor vermelha pode ser um obstáculo quando as condições comerciais requerem uma rápida distribuição e exposição dos produtos, mas de nenhuma importância prática quando a exposição ao varejo ocorrer após a redução da metamioglobina (Gill \& Jones, 1995).

\subsection{3 pH}

A variação do $\mathrm{pH}$ médio dos cortes de alcatra $(5,55-6,04)$ e de contra filé $(5,8-$ 5,6) foram normais $(\mathrm{pH}<5,8)$. Em geral, os valores médios de $\mathrm{pH}$ diminuíram ligeiramente com o tempo de estocagem. Esse efeito pode ser atribuído à dissolução do $\mathrm{CO}_{2}$ nos bifes (Ledward, 1970). Variações do pH interno e externo em relação ao sistema de embalagem e ao tempo de armazenamento sob atmosfera modificada $\left(\mathrm{CO}_{2}\right)$, estão apresentados nas Tabelas 5 e 6. 
Tabela 5. Valores médios (M) e desvio padrão (DP) de pH externo e interno dos bifes de contra filé

\begin{tabular}{lccccccccc}
\hline & \multicolumn{4}{c}{ externo } & \multicolumn{5}{c}{ interno } \\
Tratamento & \multicolumn{2}{c}{7 dias } & \multicolumn{2}{c}{14 dias } & \multicolumn{2}{c}{7 dias } & \multicolumn{2}{c}{14 dias } \\
& M & DP & M & DP & M & DP & M & DP \\
\hline Controle (C1) & 5,73 & 0,03 & 5,63 & 0,10 & 5,59 & 0,03 & 5,64 & 0,04 \\
Controle (C2) & 5,69 & 0,04 & 5,73 & 0,03 & 5,57 & 0,06 & 5,56 & 0,05 \\
PS expandido-Ageless SS400 & 5,62 & 0,09 & 5,60 & 0,06 & 5,53 & 0,06 & 5,49 & 0,05 \\
PS cristal - O-Buster FT500 & 5,68 & 0,06 & 5,65 & 0,02 & 5,58 & 0,07 & 5,51 & 0,04 \\
\hline
\end{tabular}

Tabela 6. Valores médios (M) e desvio padrão (DP) de pH externo e interno dos bifes de alcatra

\begin{tabular}{lccccccccc}
\hline \multirow{2}{*}{ Tratamento } & \multicolumn{4}{c}{ externo } & \multicolumn{5}{c}{ interno } \\
& \multicolumn{2}{c}{7 dias } & \multicolumn{2}{c}{14 dias } & \multicolumn{2}{c}{7 dias } & \multicolumn{2}{c}{14 dias } \\
& M & DP & M & DP & M & DP & M & DP \\
\hline Controle (C1) & 5,81 & 0,03 & 5,79 & 0,10 & 5,63 & 0,08 & 5,56 & 0,11 \\
Controle (C2) & 5,71 & 0,03 & n.d. & n.d. & 5,57 & 0,06 & n.d. & n.d. \\
PS expandido-Ageless SS400 & 5,70 & 0,10 & 5,69 & 0,08 & 5,57 & 0,05 & 5,52 & 0,07 \\
PS cristal - O-Buster FT500 & 5,71 & 0,02 & 5,64 & 0,04 & 5,57 & 0,06 & 5,49 & 0,04 \\
\hline
\end{tabular}

\subsubsection{Caracterização microbiológica da matéria-prima}

Inicialmente, as contagens bacterianas observadas nos músculos de contra filé e alcatra foram próximas a $4 \log \mathrm{UFC} / \mathrm{g}$ (Tabela 7), indicando as boas condições microbiológicas da matéria-prima. 
Tabela 7. Caracterização microbiológica inicial dos cortes de alcatra e contra filé (log $\mathrm{UFC} / \mathrm{g})$.

\begin{tabular}{lccc}
\hline Músculo & Mesófilos & $\begin{array}{c}\text { Psicrotróficas } \\
\text { aeróbias }\end{array}$ & $\begin{array}{c}\text { Psicrotróficas } \\
\text { anaeróbias }\end{array}$ \\
\hline Alcatra & 4,85 & 4,59 & 2,90 \\
Contra filé & 4,44 & 4,21 & 3,08 \\
\hline
\end{tabular}

Após 14 dias de armazenamento sob $\mathrm{CO}_{2}$, a contagem de organismos psicrotróficos aeróbios nos bifes de alcatra e contra filé acondicionados em bandejas de poliestireno cristal e com absorvedores O-Buster tipo FT500 manteve-se praticamente constante e próxima a $4 \mathrm{log} \mathrm{UFC} / \mathrm{g}$, enquanto que a contagem de psicrotróficos anaeróbios aumentou aproximadamente $1 \mathrm{logUFC} / \mathrm{g}$ (Tabela 8). Os resultados das contagens microbianas dos produtos armazenados em bandejas de isopor e com Ageless SS200 foram semelhantes.

Tabela 8. Contagem de microrganismos psicrotróficos aeróbios e anaeróbios, após 14 dias de armazenamento (log UFC/g).

\begin{tabular}{llcccc}
\hline \multirow{2}{*}{ Músculo } & \multirow{2}{*}{ Microrganismo } & Controle & O-Buster & Controle & Ageless \\
& & $(\mathrm{C} 1)$ & FT500 & $(\mathrm{C} 2)$ & SS200 \\
\hline Alcatra & Psicrotróficos aeróbios & 7,48 & 4,10 & 5,02 & 3,09 \\
& Psicrotróficos anaeróbios & 4,77 & 4,24 & 5,10 & 4,13 \\
Contra filé & Psicrotróficos aeróbios & 5,94 & 4,22 & 5,02 & 4,04 \\
& Psicrotróficos anaeróbios & 6,10 & 4,40 & 4,88 & 4,00 \\
\hline
\end{tabular}

A contagem bacteriana observada nos bifes de alcatra e contra filé dos tratamentos controle (C1 e C2), acondicionados sem absorvedores de oxigênio, foi sempre superior à dos sistemas de embalagens que utilizaram absorvedores de oxigênio $(\geq 5 \log \mathrm{UFC} / \mathrm{g})$. 
A partir destes resultados podemos concluir que o uso de absorvedores de oxigênio para obtenção de uma atmosfera anóxica contribuiu principalmente para a extensão da fase lag de microrganismos psicrotróficos aeróbios, potencialmente deterioradores da carne fresca.

\subsubsection{Avaliação sensorial da cor}

Após sete dias de armazenamento sob $\mathrm{CO}_{2}$, os bifes de alcatra e contra filé acondicionados em bandejas de PS cristal e sem absorvedores O-Buster FT500 apresentaram a superfície completamente marrom ou acinzentada e foram, invariavelmente, julgados inaceitáveis pela equipe sensorial, que atribui nota 10,0 na escala de cor marrom para a superfície dos bifes de contra filé e 9,0 na escala de cor castanha para os bifes de alcatra. Neste mesmo período, os bifes de alcatra e contra filé acondicionados em bandejas de PSC e com absorvedores O-Buster FT500 apresentaram diferentes intensidades e áreas de cor vermelha. Alguns bifes de alcatra armazenados com O-Buster FT500 apresentaram aproximadamente $40 \%$ de coloração vermelhocereja que contrastava com a cor vermelho escura que cobria os $60 \%$ restantes da superfície dos bifes. Outros bifes de alcatra, no entanto, apresentaram frações de coloração vermelho-cereja, típica de carnes frescas, que variaram entre 90 e 95\%, segundo observações da equipe sensorial, que atribui a esses bifes nota 9,0 na escala de cor vermelha (cor vermelha brilhante $=10,0$ ).

Alguns bifes de contra filé armazenados com absorvedores O-Buster FT500 desenvolveram uma cor vermelho-cereja que cobria de $20 \%$ a $70 \%$ da área superficial dos bifes (nota 8,0), contrastando com áreas de cor vermelha escura. Outros, no entanto, apresentaram frações de até $40 \%$ de cor marrom. Após 14 dias de armazenamento sob $\mathrm{CO}_{2}, 85-95 \%$ da superfície dos bifes de alcatra acondicionados com os absorvedores $\mathrm{O}$ Buster FT500 readquiriram a coloração vermelho-cereja, típica de carnes frescas (reblooming), e receberam notas que variaram de 9,3 a 9,5 na escala de vermelho.

Provavelmente, as altas concentrações residuais de $\mathrm{O}_{2}$ no interior das embalagens masterpack que continham as bandejas de isopor e os absorvedores de oxigênio Ageless 
SS200 $(0,471-3,18 \%)$ e as que não continham absorvedores $(1,26-3,05 \%)$ aceleraram a taxa de oxidação dos pigmentos superficiais dos bifes de alcatra e contra filé, que não desenvolveram reblooming em nenhum dos períodos avaliados.

\subsubsection{Avaliação instrumental da cor}

Imediatamente antes do acondicionamento nas embalagens masterpack, os valores médios de $\mathrm{L}^{*}$, a* e $\mathrm{b}^{*}$ do sistema CIELAB, dos bifes de alcatra foram $\mathrm{L}^{*}=35,02 \pm 3,98 ; \quad \mathrm{a}^{*}=22,03 \pm 4,52$ e $\mathrm{b}^{*}=1,42 \pm 2,70$ e dos bifes de contra filé $\mathrm{L}^{*}=34,91 \pm 3,26 ; \mathrm{a}^{*}=18,87 \pm 3,21$ e b*=0,16 $\pm 3,24$.

Decorridos 7 dias de armazenamento sob $\mathrm{CO}_{2}$, os valores médios de vermelho $\left(\mathrm{a}^{*}\right)$ dos bifes de alcatra e contra filé armazenados com absorvedores OBuster FT500 não diferiram estatísticamente dos produtos acondicionados nas bandejas de poliestireno expandido e absorvedores Ageless SS200 (Tabela 9).

Os bifes armazenados nas bandejas de PSE não readquiriram coloração vermelha após exposição aeróbica após 7 e 14 dias de armazenamento, independente do uso de absorvedores de oxigênio.

Após 14 dias de armazenamento, os valores de vermelho (a*) dos bifes de alcatra e contra filé acondicionados no masterpack em bandejas de PSC e com absorvedores de oxigênio tipo O-Buster FT500 aumentaram e foram estatísticamente superiores aos dos produtos acondicionados sem absorvedores $(\mathrm{p}=0,000)$ ou em bandejas de isopor e com Ageless SS200 (p<0,05). 
Tabela 9. Valores médios (M) e desvio padrão (DP) dos valores de a* dos bifes de alcatra e contra filé, após 7 e 14 dias de armazenamento sob $\mathrm{CO}_{2}$.

\begin{tabular}{cccccccccc}
\hline & & \multicolumn{3}{c}{ Bandeja PS cristal } & \multicolumn{3}{c}{ Bandeja PS expandido } \\
Músculo & $\begin{array}{c}\text { Tempo } \\
\text { (dias) }\end{array}$ & \multicolumn{2}{c}{ Controle $\left(\mathrm{C}_{1}\right)$} & $\begin{array}{c}\text { O-Buster } \\
\text { FT500 }\end{array}$ & \multicolumn{2}{c}{ Controle $\left(\mathrm{C}_{2}\right)$} & \multicolumn{2}{c}{$\begin{array}{c}\text { Ageless } \\
\text { SS400 }\end{array}$} \\
\hline \multirow{3}{*}{ Alcatra } & 7 & $\mathrm{M}$ & $\mathrm{DP}$ & $\mathrm{M}$ & $\mathrm{DP}$ & $\mathrm{M}$ & $\mathrm{DP}$ & $\mathrm{M}$ & $\mathrm{DP}$ \\
& 14 & $19,87^{\mathrm{a}}$ & 2,15 & $19,50^{\mathrm{a}}$ & 2,72 & $10,19^{\mathrm{b}, \mathrm{c}}$ & 1,05 & $14,61^{\mathrm{a}, \mathrm{c}}$ & 0,80 \\
& 7 & $17,30^{\mathrm{a}, \mathrm{b}}$ & 1,26 & $20,76^{\mathrm{b}}$ & 2,35 & $10,29^{\mathrm{a}}$ & 2,99 & $17,28^{\mathrm{a}, \mathrm{b}}$ & 0,09 \\
Contra filé & 14 & $15,71^{\mathrm{a}}$ & 1,07 & $22,63^{\mathrm{b}}$ & 1,07 & $13,11^{\mathrm{a}}$ & 0,72 & $11,85^{\mathrm{a}}$ & 0,20 \\
& 14 & $24,02^{\mathrm{b}}$ & 0,29 & $10,22^{\mathrm{a}}$ & 1,18 & $11,88^{\mathrm{a}}$ & 0,06 \\
\hline
\end{tabular}

$\bar{a}, b, c$ Letras diferentes na mesma linha indicam diferenças significativas $(p<0,05)$ entre os sistemas de embalagens.

Conforme pode ser observado na Tabela 10, os valores de $\mathrm{L}^{*}$ entre as amostras acondicionadas com absorvedores O-Buster FT500 e Ageless SS400 e seus respectivos controles (C1 e C2) não diferiram significativamente durante o período de estocagem ( $>>0,05)$. O efeito do tipo de bandeja sobre os valores de $\mathrm{L}^{*}$ foi avaliado, excluindo-se o efeito do absorvedor, ou seja, comparando-se os resultados obtidos entre os sistemas controles e, também neste caso, não foram encontradas diferenças estatísticas entre os dois tipos de bandeja utilizadas. 
Tabela 10. Média (M) e desvio padrão (DP) da luminosidade (L*) dos bifes de alcatra e contra filé do teste $1 \mathrm{~h}$, após 0,7 e 14 dias de armazenamento sob $\mathrm{CO}_{2}$.

\begin{tabular}{|c|c|c|c|c|c|c|c|c|c|}
\hline \multirow{3}{*}{ Músculo } & \multirow{3}{*}{$\begin{array}{l}\text { Tempo } \\
\text { (dias) }\end{array}$} & \multicolumn{4}{|c|}{ PS cristal } & \multicolumn{4}{|c|}{ PS expandido } \\
\hline & & \multicolumn{2}{|c|}{ Controle (C1) } & \multicolumn{2}{|c|}{$\begin{array}{c}\text { O-Buster } \\
\text { FT500 }\end{array}$} & \multicolumn{2}{|c|}{ Controle $(\mathrm{C} 2)$} & \multicolumn{2}{|c|}{ Ageless SS400 } \\
\hline & & $\mathrm{M}$ & $\mathrm{DP}$ & $\mathrm{M}$ & $\mathrm{DP}$ & $\mathrm{M}$ & DP & M & $\mathrm{DP}$ \\
\hline \multirow[t]{2}{*}{ Alcatra } & 7 & $38,69^{\mathrm{a}}$ & 1,42 & $38,28^{\mathrm{a}}$ & 0,92 & $35,19^{b}$ & 2,28 & $33,78^{a}$, & 1,19 \\
\hline & 14 & $37,79^{a}$ & 1,35 & $32,7^{\mathrm{a}}$ & 0,64 & $34,28^{\mathrm{a}}$ & 1,34 & $34,73^{b}$ & 0,81 \\
\hline \multirow[t]{2}{*}{ Contra filé } & 7 & $40,57^{\mathrm{a}}$ & 3,66 & $35,27^{\mathrm{a}}$ & 1,39 & $34,28^{\mathrm{a}}$ & 2,98 & $34,60^{\mathrm{a}}$ & 0,56 \\
\hline & 14 & $32,50^{\mathrm{a}}$ & 2,03 & $31,69^{\mathrm{a}}$ & 0,45 & $33,41^{\mathrm{a}}$ & 2,15 & $35,89^{\mathrm{a}}$ & 0,37 \\
\hline
\end{tabular}

a, b, chetras diferentes na mesma linha indicam diferenças significativas $(p<0,05)$ entre os sistemas de embalagens.

Na Tabela 11 pode ser observado que os valores de $b^{*}$ das amostras de alcatra acondicionadas nas bandejas de PSC e com absorvedores O-Buster FT500 não diferiram estatisticamente dos respectivos controles (C1) após 7 dias de armazenamento, mas apresentaram-se significativamente diferentes $(\mathrm{p}=0,000)$ na avaliação realizada no período seguinte $\left(14^{\mathrm{O}} \mathrm{dia}\right)$.

Não foram observadas outras diferenças significativas, entre os bifes de alcatra e contra filé acondicionados em bandejas de PSE armazenados com Ageless SS400 e seus respectivos controles. 
Tabela 11. Média (M) e desvio padrão (DP) do valor de $b^{*}$ dos bifes de alcatra e contra filé do teste 1 h, após 0,7 e 14 dias de armazenamento sob $\mathrm{CO}_{2}$.

\begin{tabular}{|c|c|c|c|c|c|c|c|c|c|}
\hline \multirow{3}{*}{ Músculo } & \multirow{3}{*}{$\begin{array}{c}\text { Tempo } \\
\text { (dias) }\end{array}$} & \multicolumn{4}{|c|}{ PS cristal } & \multicolumn{4}{|c|}{ PS expandido } \\
\hline & & \multicolumn{2}{|c|}{ Controle $\left(\mathrm{C}_{1}\right)$} & \multicolumn{2}{|c|}{$\begin{array}{c}\text { O-Buster } \\
\text { FT500 }\end{array}$} & \multicolumn{2}{|c|}{ Controle $\left(\mathrm{C}_{2}\right)$} & \multicolumn{2}{|c|}{$\begin{array}{c}\text { Ageless } \\
\text { SS400 }\end{array}$} \\
\hline & & $\mathrm{M}$ & $\mathrm{DP}$ & $\mathrm{M}$ & DP & $\mathrm{M}$ & $\mathrm{DP}$ & $\mathrm{M}$ & DP \\
\hline \multirow{2}{*}{ Alcatra } & 7 & $2,06^{\mathrm{a}}$ & 0,57 & $4,3^{\mathrm{a}}$ & 1,54 & $1,41^{\mathrm{a}}$ & 0,00 & $2,31^{\mathrm{a}}$ & 0,40 \\
\hline & 14 & $2,02^{\mathrm{a}}$ & 0,37 & $13,69^{b}$ & 0,16 & $1,50^{\mathrm{a}}$ & 0,42 & $2,56^{\mathrm{a}}$ & 0,08 \\
\hline \multirow{2}{*}{ Contra filé } & 7 & $0,10^{\mathrm{a}}$ & 1,32 & $2,97^{\mathrm{a}}$ & 0,18 & $0,31^{\mathrm{a}}$ & 0,00 & $3,15^{\mathrm{a}}$ & 1,57 \\
\hline & 14 & $5,58^{\mathrm{a}, \mathrm{b}}$ & 2,99 & $11,95^{\mathrm{b}}$ & 0,40 & $1,23^{\mathrm{a}}$ & 0,00 & $2,87^{\mathrm{a}}$ & 1,33 \\
\hline
\end{tabular}

a, b, ${ }^{c}$ Letras diferentes na mesma linha indicam diferenças significativas $(p<0,05)$ entre os sistemas de embalagens.

Dos resultados apresentados acima, podemos concluir que o tipo de bandeja e o tipo de absorvedor de oxigênio utilizados influenciaram mais significativamente os valores de $a^{*}$ que os valores de $\mathrm{L}^{*}$ ou $\mathrm{b}^{*}$, que praticamente não apresentaram diferenças significativas ao longo dos 14 dias de armazenamento.

Comparando-se o desempenho dos diferentes sistemas de embalagens em função da estabilidade da cor vermelha, podemos concluir que o acondicionamento dos bifes em bandejas de poliestireno cristal (PSC) e com absorvedores O-Buster FT500 foi o único sistema capaz de evitar a descoloração irreversível da mioglobina, apesar da reoxigenação ter ocorrido somente após 14 dias de armazenamento.

Este "atraso" na reoxigenação pode ser evitado, minimizando-se o teor de oxigênio livre nas embalagens masterpack, através do uso de absorvedores de oxigênio, para prevenir o aumento da concentração de $\mathrm{O}_{2}$ no interior do masterpack, a ponto de não permitir a descoloração transitória observada nos primeiros 7 dias de armazenamento.

Absorvedores de oxigênio são potencialmente capazes de prevenir aumentar a vida útil da carne fresca, mas fatores tais como o tipo de absorvedor, seleção do sistema 
de embalagem e atmosfera gasosa $\left(\mathrm{N}_{2} / \mathrm{CO}_{2}\right)$ podem afetar os resultados (Tewari et. al., 2001).

A seguir foram realizados outros dois testes preliminares com o objetivo de selecionar o melhor tipo de absorvedor de oxigênio e de filme primário para o acondicionamento da carne bovina em sistema masterpack com $100 \% \mathrm{CO}_{2}$ ).

\subsection{Efeito do tipo de absorvedor de oxigênio}

Apesar da vantagem técnica da utilização de bandejas de poliestireno cristal, esta bandeja não foi selecionada nos experimentos seguintes porque possui um custo de cerca de três vezes maior que o das bandejas de isopor. O custo é um fator limitante para a difusão desta tecnologia, daí a necessidade de buscar componentes de menor custo.

Além disso, a bandeja de isopor para o acondicionamento de carne fresca é mais familiar ao consumidor e ainda não existe no mercado brasileiro, bandeja cristal de baixa altura para o acondicionamento de carne fresca, pois este tipo de bandeja é mais difundida para a comercialização de vegetais minimamente processados.

\subsubsection{Avaliação do oxigênio residual nas embalagens tipo masterpack}

Os valores médios das avaliações dos teores residuais de oxigênio nas embalagens tipo mastepack são apresentados na Figura 6. 


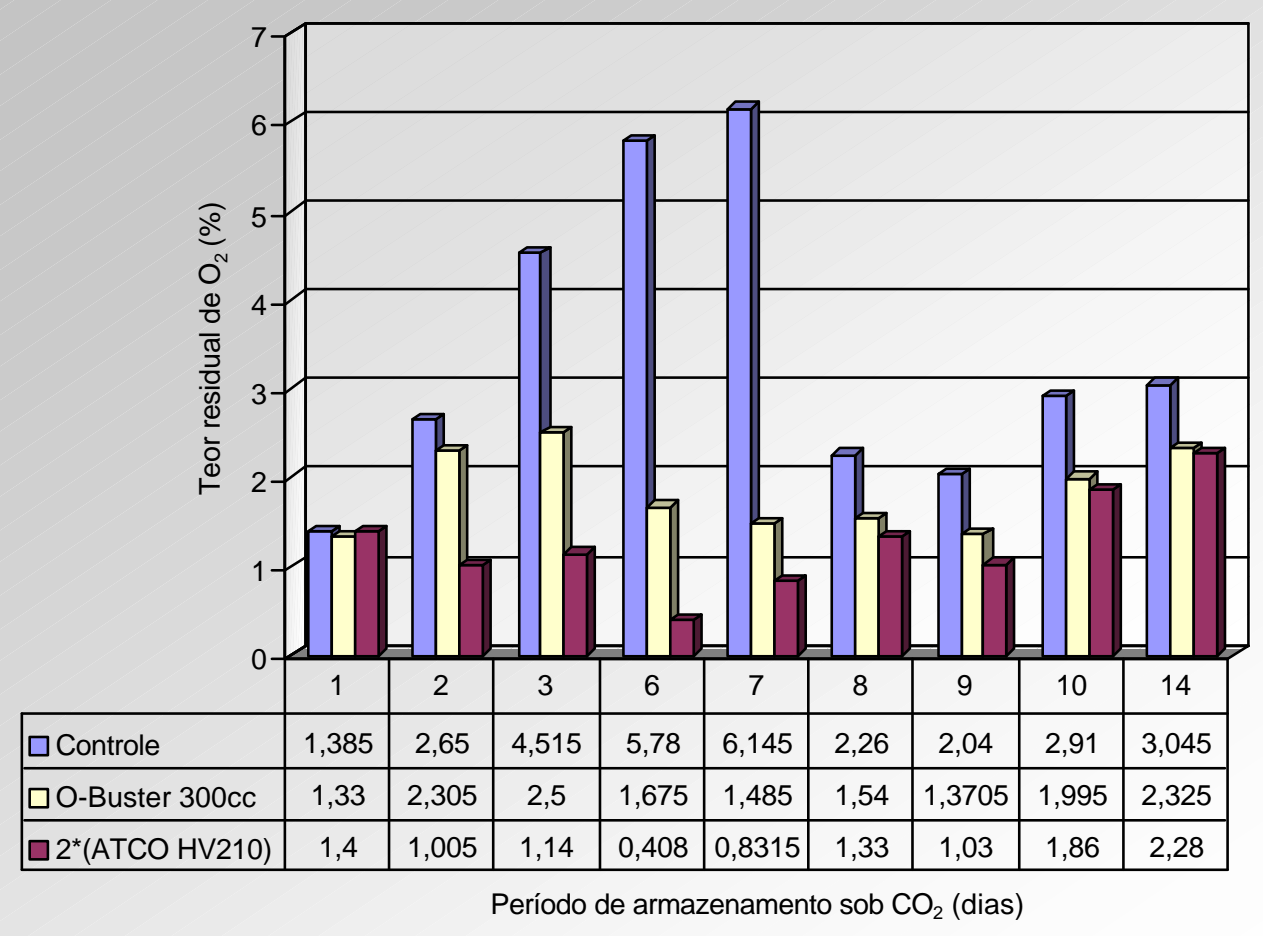

Figura 6 - Teor de oxigênio em masterpack em função do tipo do tipo de absorvedor de oxigênio.

Até o $9^{\circ}$ dia de armazenamento sob $\mathrm{CO}_{2}$, o teor residual de oxigênio no interior das embalagens que continham absorvedores de oxigênio O-Buster FT300 foi superior ao das embalagens controle, que não continham absorvedores.

Os absorvedores de oxigênio O-Buster FT300, nominalmente capazes de absorver $300 \mathrm{~cm}^{3}$ de oxigênio, não foram eficientes na diminuição do oxigênio residual das embalagens masterpack, provavelmente porque este absorvedor não seja apropriado para uso em temperaturas de refrigeração, conforme comunicação pessoal fornecida pelo fabricante, após o término deste teste preliminar.

No entanto, o absorvedor ATCO HV 420, nominalmente capaz de absorver $420 \mathrm{~cm}^{3}$ de oxigênio, diminuiu o teor residual de $\mathrm{O}_{2}$ livre das embalagens para valores próximos de $1 \%$ entre o quarto e o quinto dia de armazenamento e para $0 \%$ entre o $7^{\circ}$ e o $14^{\mathrm{o}}$ dia. O período exato da redução para $0 \%$ não foi determinado porque não foram 
realizadas medidas da porcentagem de $\mathrm{O}_{2}$ naquele intervalo, para evitar possível vazamento do gás $\mathrm{CO}_{2}$ durante a medição do gás.

\subsection{2 $\mathrm{pH}$}

Antes da embalagem em atmosfera modificada $\left(\mathrm{CO}_{2}\right)$, o $\mathrm{pH}$ interno médio dos bifes de alcatra foi 5,56. Em geral, os valores médios de $\mathrm{pH}$ diminuíram ligeiramente ou mantiveram-se aproximadamente constante durante os 14 dias de armazenamento sob $\mathrm{CO}_{2}$. Variações do $\mathrm{pH}$ interno e externo em relação ao sistema de embalagem e ao tempo de armazenamento sob atmosfera modificada $\left(\mathrm{CO}_{2}\right)$, estão apresentados na Tabela 12.

Tabela 12. Efeitos do uso de absorvedor de oxigênio e do tempo de armazenamento sob $\mathrm{CO}_{2}$, sobre os valores de $\mathrm{pH}$ interno dos bifes de alcatra.

\begin{tabular}{lccccccc}
\hline Músculo & Tempo & \multicolumn{2}{c}{ Controle } & \multicolumn{2}{c}{ O-Buster FT300 } & \multicolumn{2}{c}{ ATCO HV420 } \\
\cline { 2 - 8 } & (dias) & $\mathrm{M}$ & $\mathrm{DP}$ & $\mathrm{M}$ & $\mathrm{DP}$ & $\mathrm{M}$ & $\mathrm{DP}$ \\
\hline Alcatra & 7 & 5,59 & 0,05 & 5,60 & 0,04 & 5,62 & 0,04 \\
& 14 & 5,45 & 0,07 & 5,42 & 0,12 & 5,45 & 0,19 \\
\hline
\end{tabular}

\subsubsection{Caracterização microbiológica da matéria-prima}

Inicialmente, os bifes de alcatra apresentaram contagens microbianas que indicaram que foram adotadas as boas práticas de manipulação durante o abate, a desossa e a preparação dos bifes (Tabela 13). 
Tabela 13. Caracterização microbiológica inicial dos bifes de alcatra (log UFC/g).

\begin{tabular}{cccc}
\hline & Mesófilos & $\begin{array}{c}\text { Psicrotróficas } \\
\text { aeróbias }\end{array}$ & $\begin{array}{c}\text { Psicrotróficas } \\
\text { anaeróbias }\end{array}$ \\
\cline { 2 - 4 } Matéria-prima & 2,3 & 4,7 & 4,4 \\
\hline
\end{tabular}

A Tabela 14 mostra que a qualidade microbiológica dos bifes de alcatra foi mais influenciada pelo efeito inibitório do uso de $\mathrm{CO}_{2}$ do que pelo uso de absorvedores de oxigênio. Após 14 dias de armazenamento, o número de bactérias psicrotróficas aeróbias sobre a superfície dos bifes de alcatra foi próximo ou inferior a $6 \log \mathrm{UFC} / \mathrm{g}$, independente do uso de absorvedores de oxigênio.

Tabela 14. Efeito do tipo de absorvedor sobre a contagem de bactérias psicrotróficas aeróbias e anaeróbias dos bifes de alcatra $(\log \mathrm{UFC} / \mathrm{g})$, após 14 dias de armazenamento sob $\mathrm{CO}_{2}$.

\begin{tabular}{lcccc}
\hline Tratamento & \multicolumn{2}{c}{ Psicrotróficas aeróbias } & \multicolumn{2}{c}{ Psicrotróficas anaeróbias } \\
& M & DP & M & DP \\
\hline Controle & 6,15 & 0,00 & n.d. & n.d. \\
O-Buster FT300 & 5,00 & 0,25 & 5,03 & 0,27 \\
ATCO HV420 & 5,97 & 0,05 & 5,28 & 0,86 \\
\hline
\end{tabular}

O crescimento de bactérias psicrotróficas aeróbias não foi depende do uso de absorvedores de oxigênio. As diferenças na concentração residual de oxigênio não se traduziram em diferenças na contagem de psicrotróficos aeróbios. Apesar do menor teor residual de oxigênio ter ocorrido nas embalagens masterpack que continham absorvedores ATCO HV420, o número de psicrotróficos aeróbios que recobriam os bifes acondicionados neste sistema foi aproximadamente 1 ciclo logarítmico superior ao dos produtos acondicionados com O-Buster FT300 e próxima da contagem observada nos bifes do tratamento controle (sem absorvedores de oxigênio). 
$\mathrm{O}$ número de bactérias psicrotróficas anaeróbias nos bifes de alcatra acondicionados com O-Buster FT300 também foi um pouco inferior ao dos bifes acondicionados com ATCO HV420.

\subsubsection{Avaliações sensoriais e objetivas da cor do músculo}

No $7^{\circ}$ e $14^{\circ}$ dia de armazenamento sob $\mathrm{CO}_{2}$, os bifes de alcatra estocados com absorvedores O-Buster FT300 e os do tratamento controle não desenvolveram reblooming. A equipe sensorial observou frações consideráveis de manchas marrom na superfície dos bifes (50-80\%).

Em contrapartida, os bifes acondicionados com os absorvedores ATCO420HV readquiriram coloração vermelha após exposição aeróbica e apresentaram somente pequenas frações de manchas marrom $(<10 \%)$, nos períodos avaliados. A maior reoxigenação dos bifes acondicionados com ATCO HV420 ocorreu após 14 dias de armazenamento.

A observação da maior ocorrência de áreas descoloridas nas laterais das bandejas pode estar relacionada a falhas na selagem do filme primário ou a maior pressão de $\mathrm{O}_{2}$ nas regiões onde a altura da bandeja impedia que o filme aderisse à superfície dos bifes.

Paralelamente, observou-se que os valores médios de vermelho $\left(\mathrm{a}^{*}\right)$ dos bifes armazenados com ATCO HV420 também foram significativamente superiores aos dos demais tratamentos (Tabela 15). 
Tabela 15. Efeitos do uso de absorvedor de oxigênio e do tempo de armazenamento sob $\mathrm{CO}_{2}$, sobre os valores de $\mathrm{pH}$ dos bifes de alcatra ${ }^{1}$.

\begin{tabular}{|c|c|c|c|c|c|c|c|c|c|c|c|c|}
\hline & \multicolumn{6}{|c|}{7 dias } & \multicolumn{6}{|c|}{14 dias } \\
\hline & $\mathrm{L}^{*}$ & & $a^{*}$ & & $b^{*}$ & & $\mathrm{~L}$ & & $a^{*}$ & & $b^{*}$ & \\
\hline & Média & DP & Média & DP & Média & DP & Média & DP & Média & DP & Média & DP \\
\hline Controle & $36,98^{\mathrm{a}}$ & 3,93 & $11,80^{\mathrm{a}}$ & 1,90 & $3,10^{\mathrm{a}}$ & 2,21 & $36,98^{\mathrm{a}}$ & 3,93 & $11,80^{\mathrm{a}}$ & 1,25 & $7,27^{\mathrm{a}}$ & 1,49 \\
\hline O-Buster FT300 & $38,02^{\mathrm{a}}$ & 0,22 & $11,00^{\mathrm{a}}$ & 0,32 & $5,02^{\mathrm{a}}$ & 0,74 & $38,02^{\mathrm{a}}$ & 0,22 & $11,00^{\mathrm{a}}$ & 0,49 & $5,85^{\mathrm{a}}$ & 1,00 \\
\hline ATCO HV420 & $34,34^{\mathrm{b}}$ & 0,82 & $16,15^{\mathrm{a}}$ & 4,79 & $3,84^{\mathrm{a}}$ & 0,61 & $34,34^{\mathrm{b}}$ & 0,82 & $16,15^{\mathrm{a}}$ & 0,13 & $8,36^{\mathrm{a}}$ & 1,04 \\
\hline
\end{tabular}

${ }^{1}$ Letras diferentes numa mesma coluna indicam diferenças significativas $(\mathrm{p}<0,00)$ entre os tratamentos.

Decorridos 7 e 14 dias de armazenamento e imediatamente após a reoxigenação, as amostras de alcatra acondicionadas com ATCO HV420 exibiram coloração vermelhocereja, típica de carne fresca, enquanto que as amostras acondicionadas com O-Buster e as amostras do tratamento controle apresentaram uma coloração acinzentada clara, característica de carne deteriorada. Consequientemente, os valores de $\mathrm{L}^{*}$ dos bifes de alcatra das amostras acondicionadas com ATCO HV420 foram estatisticamente superiores aos valores de $\mathrm{L}^{*}$ das amostras dos demais tratamentos, nos dois períodos avaliados $(\mathrm{p}<0,005)$.

Os valores de $b^{*}$ entre os tratamentos não variaram estatisticamente entre si e, portanto, podemos concluir que não foram influenciados pelo uso de absorvedores de oxigênio.

Considerando-se o bom desempenho dos absorvedores ATCO HV420 no rápido seqüestro do oxigênio residual e, conseqüentemente, o aumento da vida útil da cor vermelha dos bifes de alcatra por até 14 dias, podemos predizer que muito provavelmente este sistema também previna a descoloração de cortes em bifes de músculos de contra filé, com maior estabilidade de cor inerente.

Tewari (2001) e Gill \& McGinnis (1995) desenvolveram estudos sobre a cinética de absorção de oxigênio e observaram que a capacidade de absorção dos absorvedores disponíveis comercialmente diminui exponencialmente quando são atingidas concentrações inferiores a 1\%, e concluíram que a descoloração somente pode ser evitada se um grande número de absorvedores for utilizado em cada embalagem. 
Assim, considerando-se os estudos sobre a cinética de absorção de oxigênio realizados pelos pesquisadores Gill \& McGinnis (1995) e Tewari et al. (2001) e a sugestão informal do pesquisador Legrand responsável técnico da empresa Standa Industrie, que comercializa os absorvedores ATCO, os testes descritos a seguir foram conduzidos utilizando absorvedores com capacidade nominal de seqüestrar $1000 \mathrm{~cm}^{3}$ de oxigênio.

\subsection{Efeito do tipo de filme primário}

Inicialmente este trabalho previa a avaliação da vida útil da carne armazenada por 14 dias sob $\mathrm{CO}_{2}$. Nos primeiros testes preliminares observamos a formação transitória de metamioglobina nos bifes acondicionados com absorvedores de oxigênio, em virtude da presença de oxigênio residual no interior das embalagens masterpack, e também, a redução da metamioglobina formada à deoximioglobina entre $0 \quad 7$ e $0 \quad 14^{\circ}$ dia de armazenamento sob $\mathrm{CO}_{2}$, quando de fato a carne apresentava uma coloração vermelha atraente após exposição aeróbica. Esse 'atraso' na reoxigenação e a possibilidade técnica de prolongarmos a estabilidade da cor por mais do que 14 dias, levou-nos a estender o período de armazenamento sob $\mathrm{CO}_{2}$ de 14 para 42 dias, no teste para escolha do filme primário, bem como no teste final, com o melhor sistema de embalagem.

\subsubsection{Avaliação do oxigênio residual nas embalagens tipo masterpack}

O teor de oxigênio (\%) no interior dos sacos masterpack nos primeiros dias após o fechamento das embalagens e imediatamente antes da sua abertura, após 7, 14, 21 e 28 dias de armazenamento sob $\mathrm{CO}_{2}$ a $1 \pm 1^{\circ} \mathrm{C}$, estão apresentados na Figura 7.

A perfuração longitudinal e transversal do filme Clysar favoreceu a evacuação do ar ocluso sob o filme primário. Comparando-se a concentração residual de oxigênio das embalagens masterpack dos tratamentos controle, pode-se observar que as embalagens dos sistemas que continham bandejas envoltas com filme Clysar apresentaram teores residuais de oxigênio pouco inferiores às embalagens masterpack que continham 
bandejas envoltas em filme de PVC. No entanto, essa diferença não tem nenhuma importância prática, uma vez que somente com o uso de absorvedores de oxigênio foi possível eliminar completamente o oxigênio e evitar a descoloração.

Os bifes armazenados sem absorvedores de oxigênio não readquiriram coloração vermelha após exposição aeróbica, em nenhum dos períodos avaliados (7, 14, 21 e 28 dias). Portanto, o uso dos absorvedores ATCO HV1000 absorvedores de oxigênio para obtenção de uma atmosfera virtualmente livre de oxigênio foi fundamental para previnir a descoloração da carne.

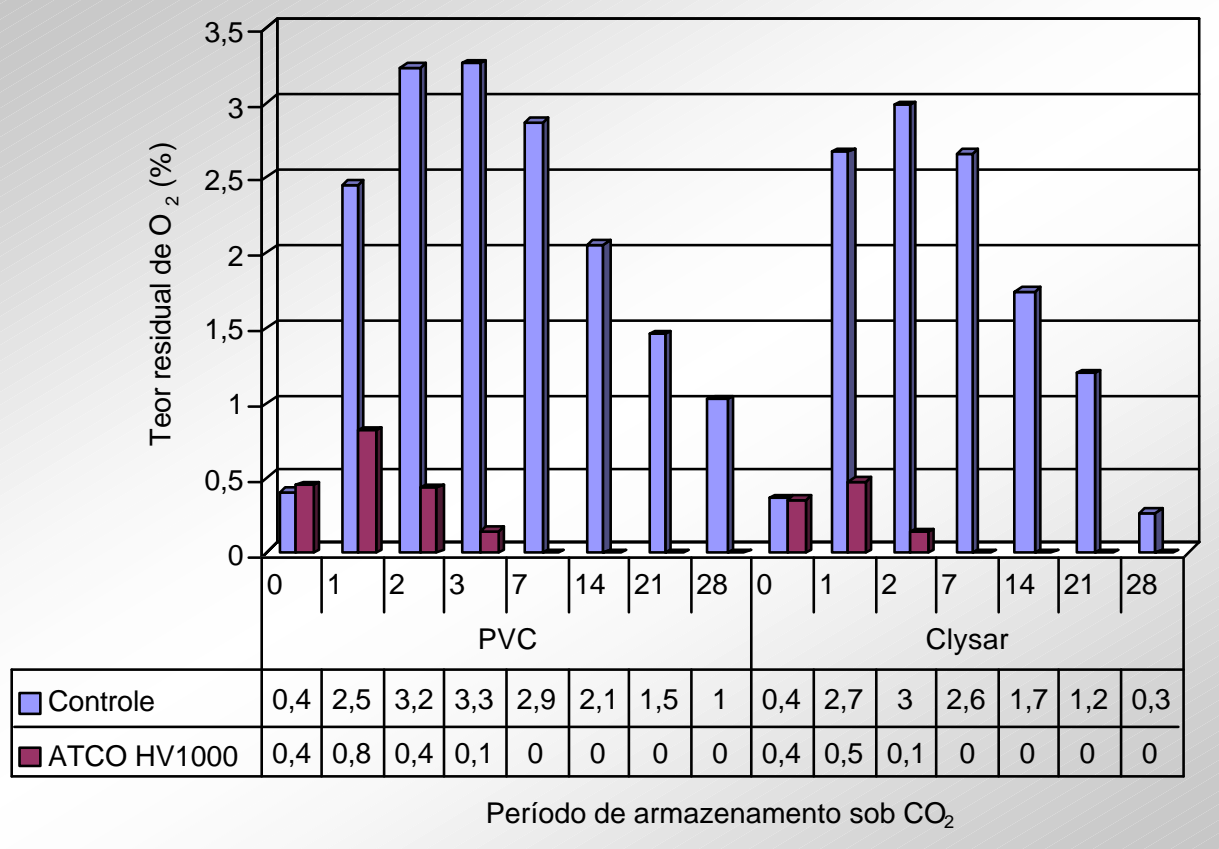

Figura 7 - Teor de oxigênio no masterpack em função do tipo de filme primário.

\subsection{2 pH}

O tipo de filme primário e o uso de absorvedores não influenciaram significativamente os valores de $\mathrm{pH}$ dos bifes de contra filé (Figura 8) e alcatra (Figura 9) que foram geralmente normais $(\mathrm{pH}, 5,8)$ em todos nos períodos avaliados. 


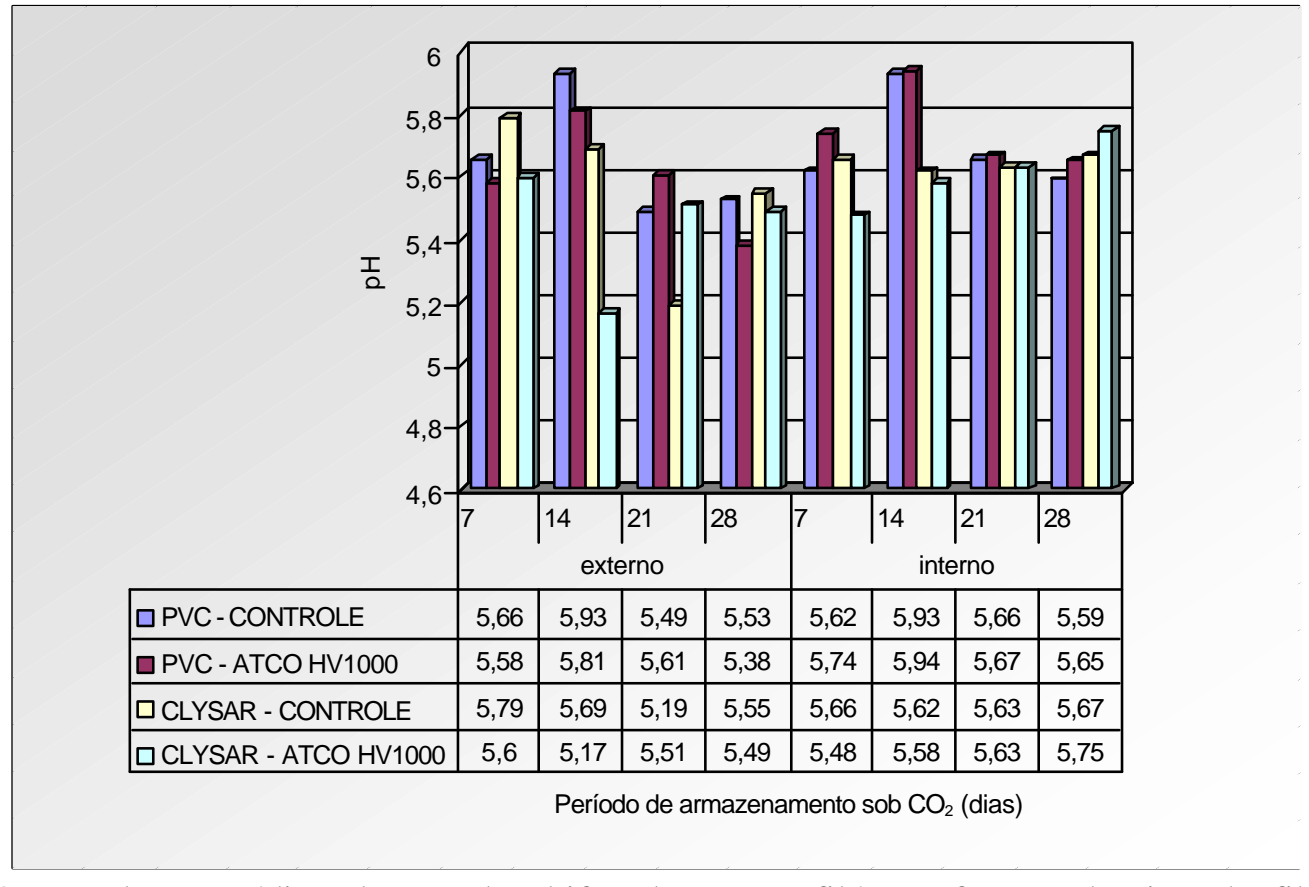

Figura 8 - Valores médios de $\mathrm{pH}$ dos bifes de contra filé em função do tipo de filme primário.

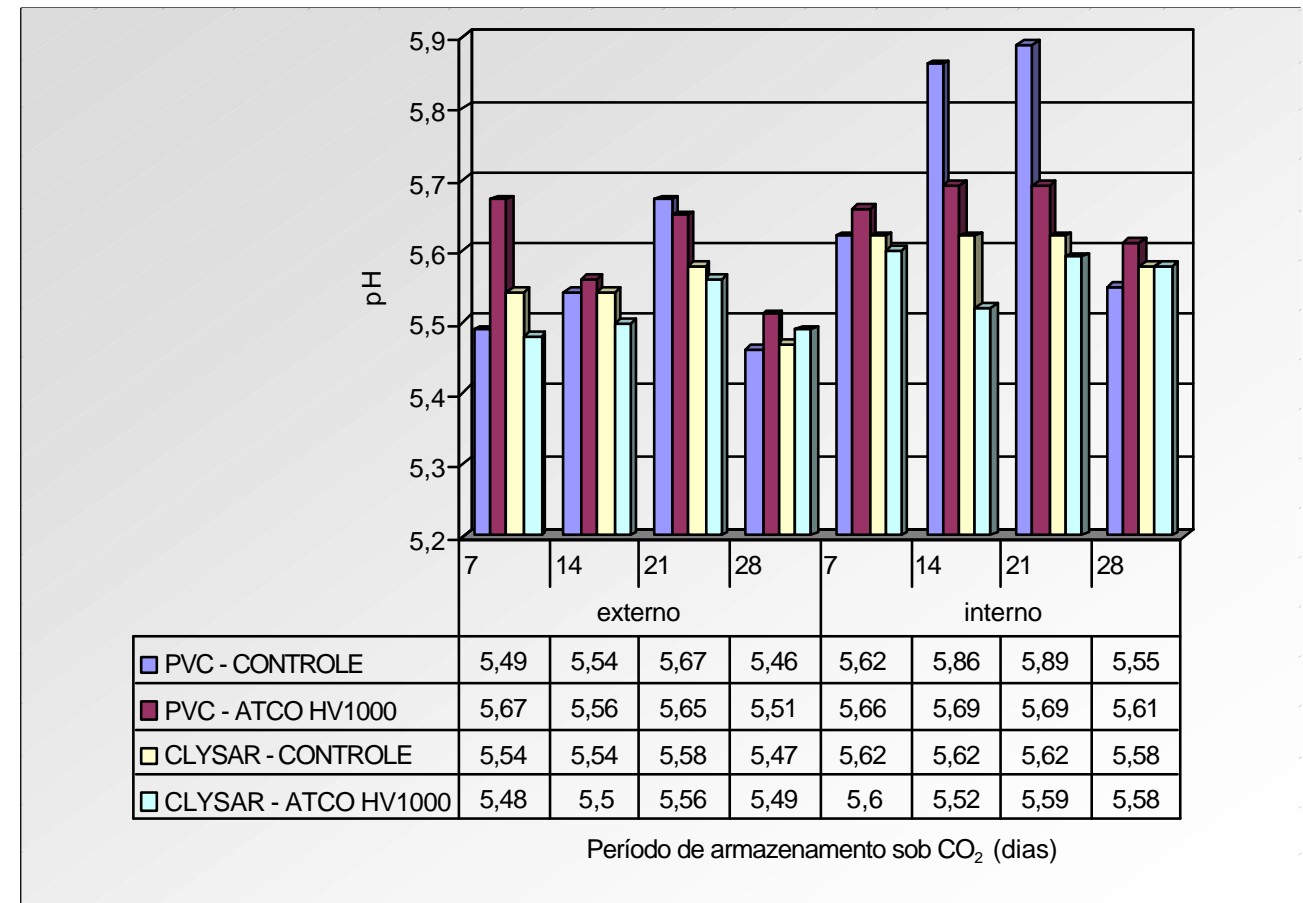

Figura 9 - Valores médios de $\mathrm{pH}$ dos bifes de alcatra em função do tipo de filme primário. 


\subsubsection{Avaliação microbiológica da matéria-prima}

Na Tabela 16 são apresentados os resultados da caracterização microbiológica da matéria-prima.

Tabela 16. Caracterização microbiológica da matéria-prima utilizada no teste preliminar para escolha do tipo de filme primário.

\begin{tabular}{lccc}
\hline Microrganismos & Resultados log UFC/g & $\begin{array}{c}\text { Padrões da legislação } \\
\log \text { UFC/g }\end{array}$ \\
\hline Coliformes Totais & Alcatra & Contra-filé & \\
Coliformes Fecais & $\geq 3,38$ & $\geq 3,38$ & n.c \\
Mesófilos aeróbios & 1,36 & 1,41 & $2,5^{(\text {b) }}$ \\
S.aureus & 5,47 & 5,44 & $6,5^{(\text {b) }}$ \\
Salmonella sp & $<2,0$ & $<2,0$ & n.c \\
Psicotróficas anaeróbias & Ausência & Ausência & Ausência \\
Psicotróficas aeróbias & 5,47 & 5,92 & n.c \\
Bactérias Láticas & 5,47 & 5,29 & n.c \\
Clostridium Sulfito Redutor & $<1,0$ & 5,02 & n.c \\
\hline
\end{tabular}

$\geq$ : Valor estimado, detectado pela maior diluição utilizada.

$<$ : Valor estimado, detectado pela menor diluição utilizada.

n.c.: nada consta

(a): Resolução-RDCn ${ }^{\circ}$ 12-Regimento Técnico sobre padrões microbiológicos para alimentos-Anvisa/MS-02/01/2001.

(b): Código Sanitário - Secretaria de Vigilância Sanitária do Estado de São Paulo - Decreto ${ }^{\circ} 12.342$ de $27 / 08 / 78$.

As análises microbiológicas realizadas para caracterização da carne de alcatra e contra filé revelaram altas contagens microbianas. A alta carga bacteriana pode ter sido causada pelas condições de abate no lugar de origem ou pela grande distância percorrida pela carne dentro do caminhão refrigerado, desde o frigorífico até sua chegada no Centro de Tecnologia de Carnes do Ital. Além disso, os resultados das análises de coliformes 
fecais e totais, 1,36 e 3,38 UFC/g nos bifes de alcatra e 1,41 e 3,38 UFC/g, nos bifes de contra filé, revelam que não foram adotadas as Boas Práticas de Manipulação na manipulação e no acondicionamento da matéria-prima.

\subsubsection{Avaliação microbiológica dos produtos após armazenamento sob $\mathrm{CO}_{2}$}

A vida útil dos bifes de alcatra e contra filé foi limitada pela alta carga de microrganismos psicrotróficos aeróbios.

Nas avaliações microbiológicas realizadas para seleção do filme primário, a população de bactérias psicrotróficas aeróbias das amostras de contra filé (Figura 10) e alcatra (Figura 11) acondicionadas com ou sem absorvedores de oxigênio foi geralmente superior a $10^{6} \mathrm{UFC} / \mathrm{g}$ durante as três primeiras semanas de armazenamento sob $\mathrm{CO}_{2} \mathrm{e}$ próxima de $10^{8} \mathrm{UFC} / \mathrm{g}$ na quarta semana de acondicionamento anaeróbico.

O uso de absorvedor de oxigênio não influenciou as contagens de bactérias psicrotróficas aeróbias.

Em todos os períodos avaliados (7, 14, 21 e 28 dias), as contagens de microrganismos psicrotróficos aeróbios presentes na superfície dos bifes de contra filé e alcatra armazenados com absorvedor de oxigênio foram muito próximas $(<1$ ciclo logarítmico) das contagens observadas nos bifes acondicionados sem absorvedor, sendo que em alguns períodos a contagem de psicrotróficos aeróbicos foi maior nos bifes acondicionados com absorvedor de oxigênio. O gás apenas induziu uma pequena desaceleração na multiplicação dos microrganismos que já estavam presentes em altas quantidades na matéria-prima.

A atividade bacteriana é um fator importante na alteração de cor de carnes frescas. Bactérias psicrotróficas aeróbias tais como as Pseudomonas demonstraram ser pró-oxidantes em baixas contagens $\left(10^{4} \mathrm{UFC} / \mathrm{g}\right)$ e pró-redutoras com uma aparente redução na concentração de metamioglobina em aproximadamente $10^{8} \mathrm{UFC} / \mathrm{g}$ (Faustman e Cassens, 1990).

Os altos valores de vermelho $\left(\mathrm{a}^{*}\right)$ dos bifes de alcatra e contra filé armazenados com ATCO HV1000 entre 1h e 24h de exposição aeróbica, durante todos os períodos de 
armazenamento sob $\mathrm{CO}_{2}(7,14,21$ e 28 dias), podem ser resultado do efeito pró-redutor da alta carga bacteriana.

Também não se observou diferença no crescimento de bactérias psicrotróficas anaeróbias (Figura 12 e Figura 13) e bactérias láticas (Figura 14 e Figura 15) entre as amostras acondicionadas com ATCO HV1000 ou sem absorvedor de oxigênio (controle).

Com base nesses resultados, conclui-se que o uso de absorvedores de oxigênio teve pouco efeito sobre o crescimento de psicrotróficos aeróbios, psicrotróficos anaeróbios e bactérias láticas em bifes de alcatra e contra filé, provavelmente porque as contagens iniciais desses microrganismos nos dois tipos de corte já se apresentavam na fase exponencial, próximo de $10^{5}$ e $10^{6} \log \mathrm{UFC} / \mathrm{g}$ na matéria-prima.

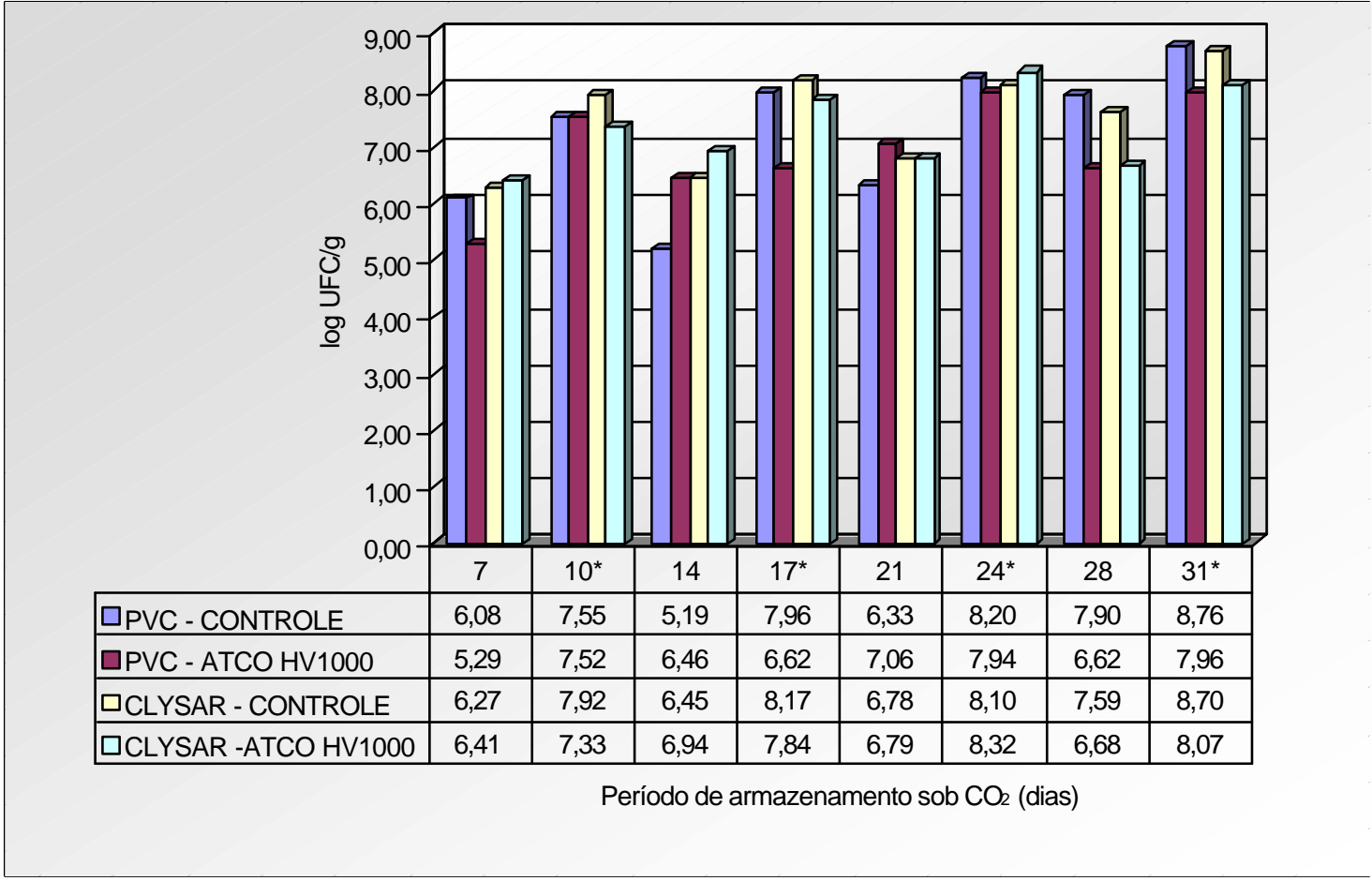

Figura 10 - Contagem de psicrotróficos aeróbios nos bifes de contra filé. 


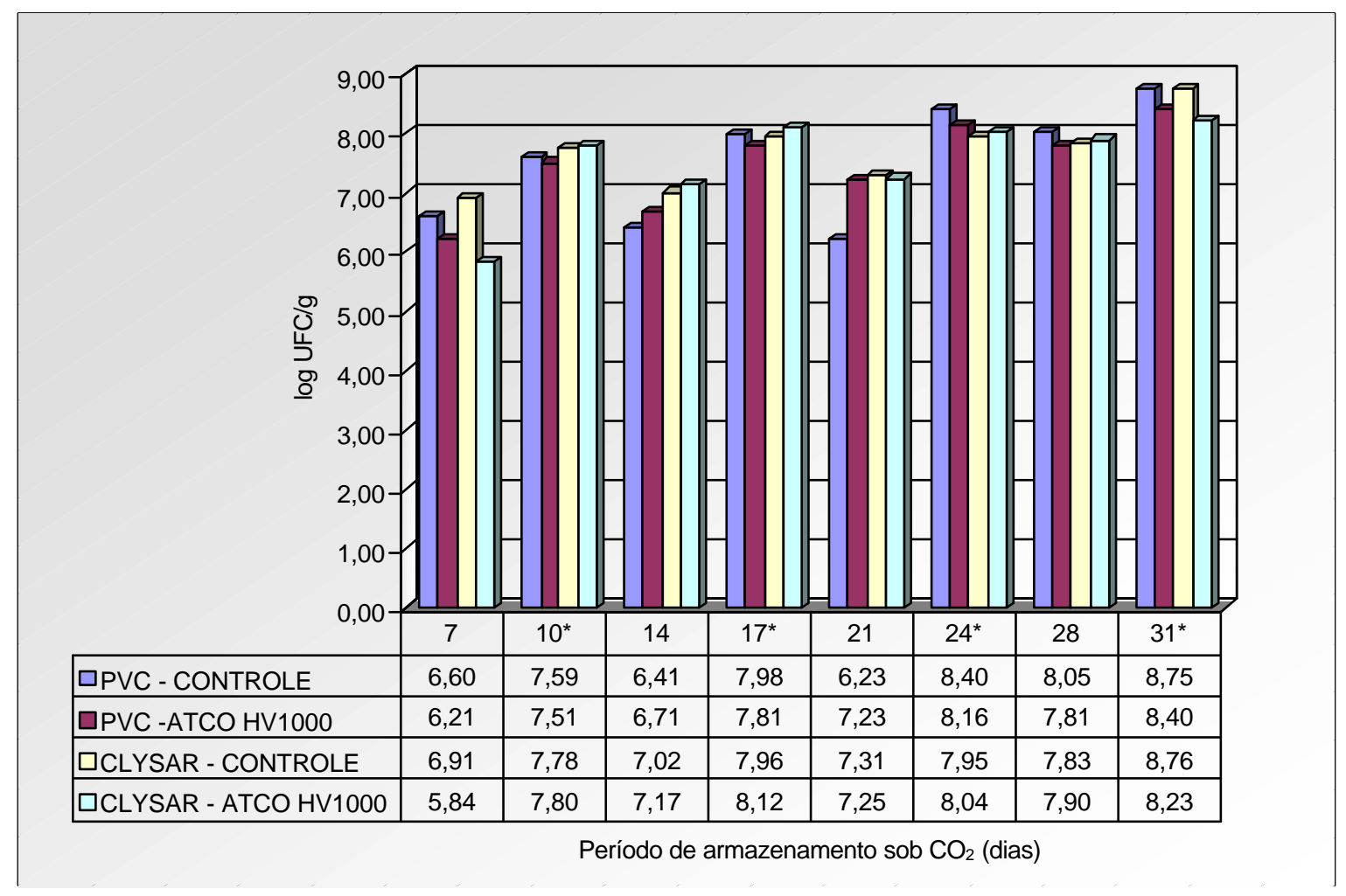

Figura 11 - Contagem de psicrotróficos aeróbios nos bifes de alcatra.

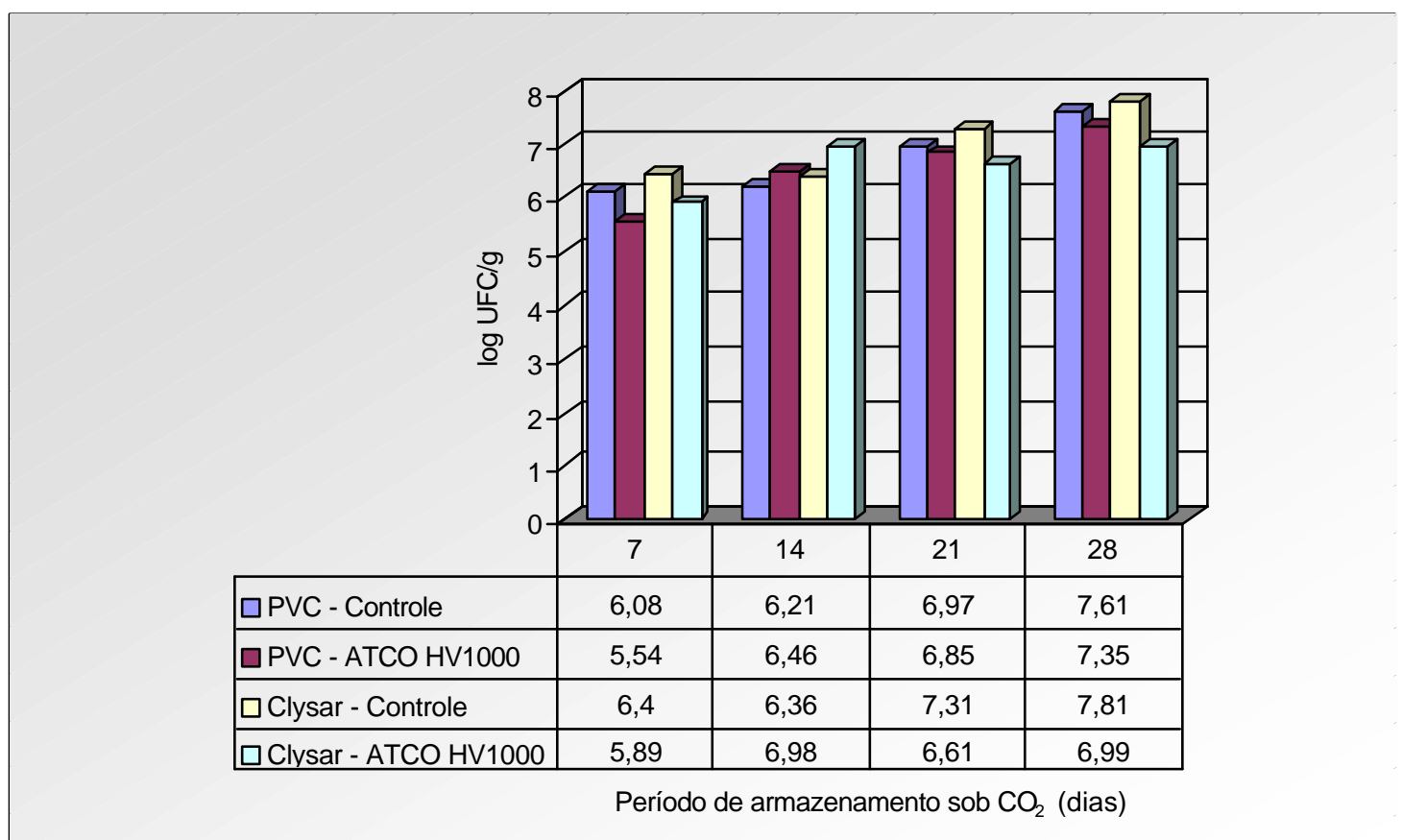

Figura 12 - Contagem de psicrotróficos anaeróbios nos bifes de contra filé. 


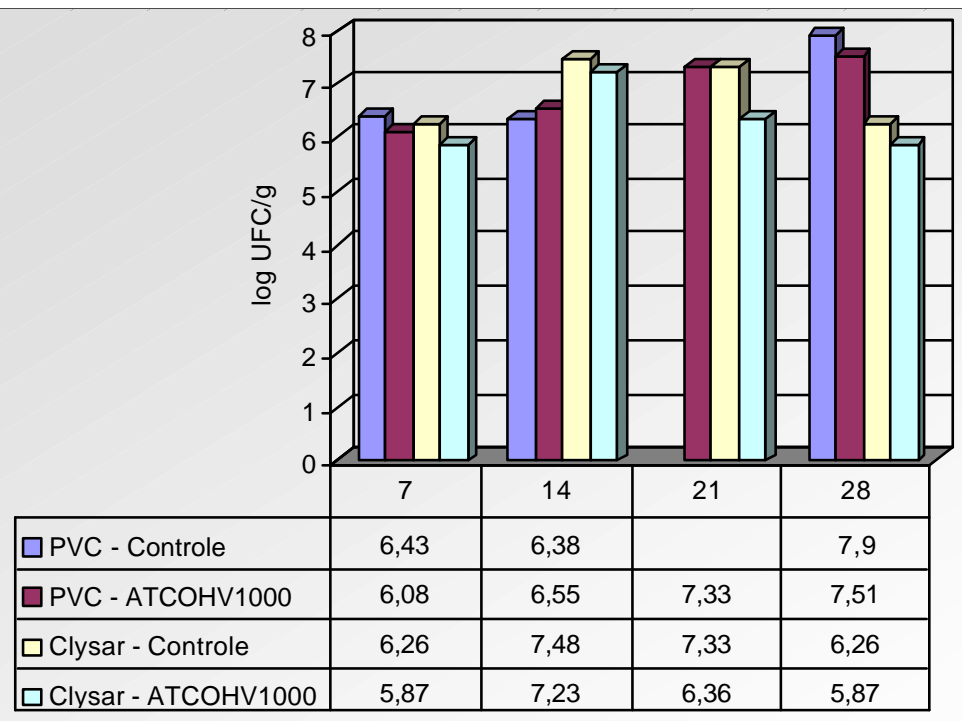

Período de armazenamento sob $\mathrm{CO}_{2}$ (dias)

Figura 13 - Contagem de microrganismos psicrotróficos anaeróbios nos bifes de alcatra.

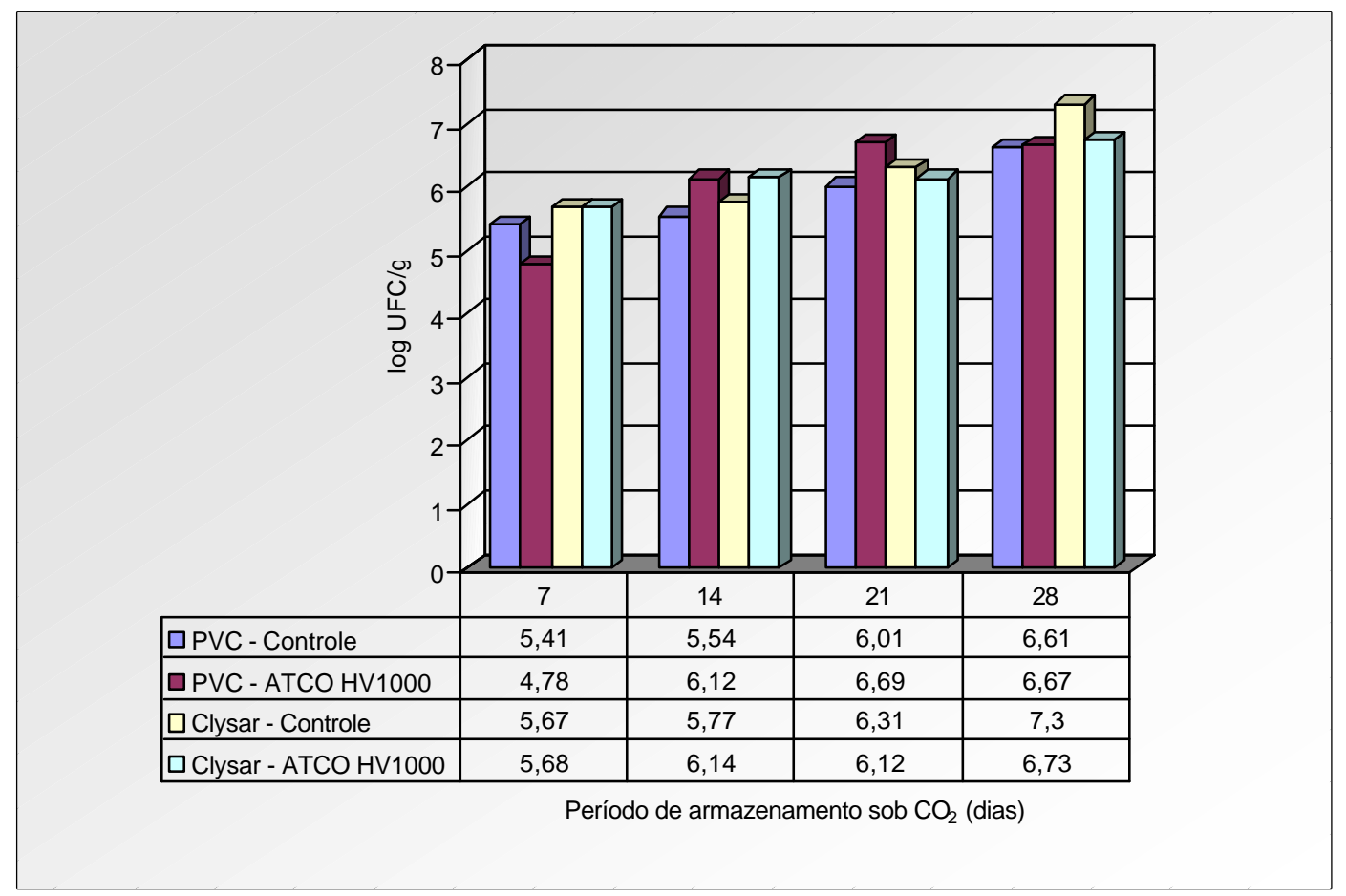

Figura 14 - Contagem de bactérias láticas nos bifes de contra filé. 


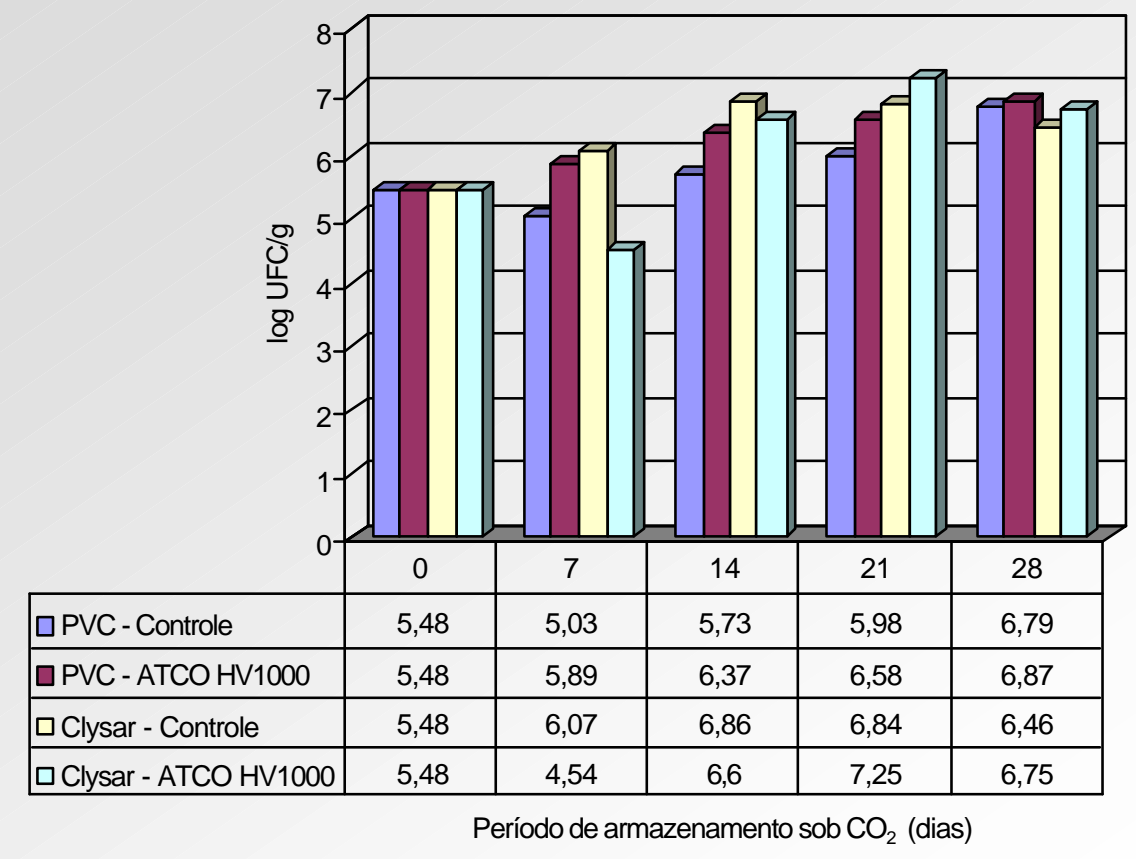

Figura 15 - Contagem de bactérias láticas nos bifes de alcatra.

\subsubsection{Avaliação sensorial e instrumental da cor}

\subsubsection{Contra filé}

A Figura 16 podemos observar que o tipo de filme primário que envolvia as bandejas não influenciou significativamente a cor vermelha sensorial dos bifes de contra filé ao longo das 48h de exposição aeróbica nos períodos avaliados (7, 14, 21 e 28 dias).

$\mathrm{O}$ oxigênio residual presente no interior das embalagens masterpack que continham absorvedores de oxigênio $\left(0,1-0,8 \% \mathrm{O}_{2}\right)$, durante os primeiros dias de armazenamento, induziu a formação de pequenas frações de metamioglobina (marrom) na superfície dos bifes em todos os sistemas de embalagens avaliados. 
Não foi observada diferença significativa na cor vermelha sensorial entre as amostras acondicionadas com ou sem absorvedores de oxigênio durante a primeira semana de armazenamento, e a cor exibida pelas amostras de ambos tratamentos foi vermelha e próxima da cor vermelha típica de carne fresca $(7,0)$.

Nos períodos subseqüentes, a cor vermelha sensorial dos bifes de contra filé acondicionados com ATCO HV1000 foi estatisticamente superior à cor exibida pelos bifes dos tratamentos controle $(\mathrm{p}=0,000)$.

O oxigênio residual nas embalagens que não continham absorvedores de oxigênio (controle) impediu o desenvolvimento da cor vermelha na superfície dos bifes, que apresentaram cor superficial marrom a partir do $14^{\circ}$ dia de armazenamento.

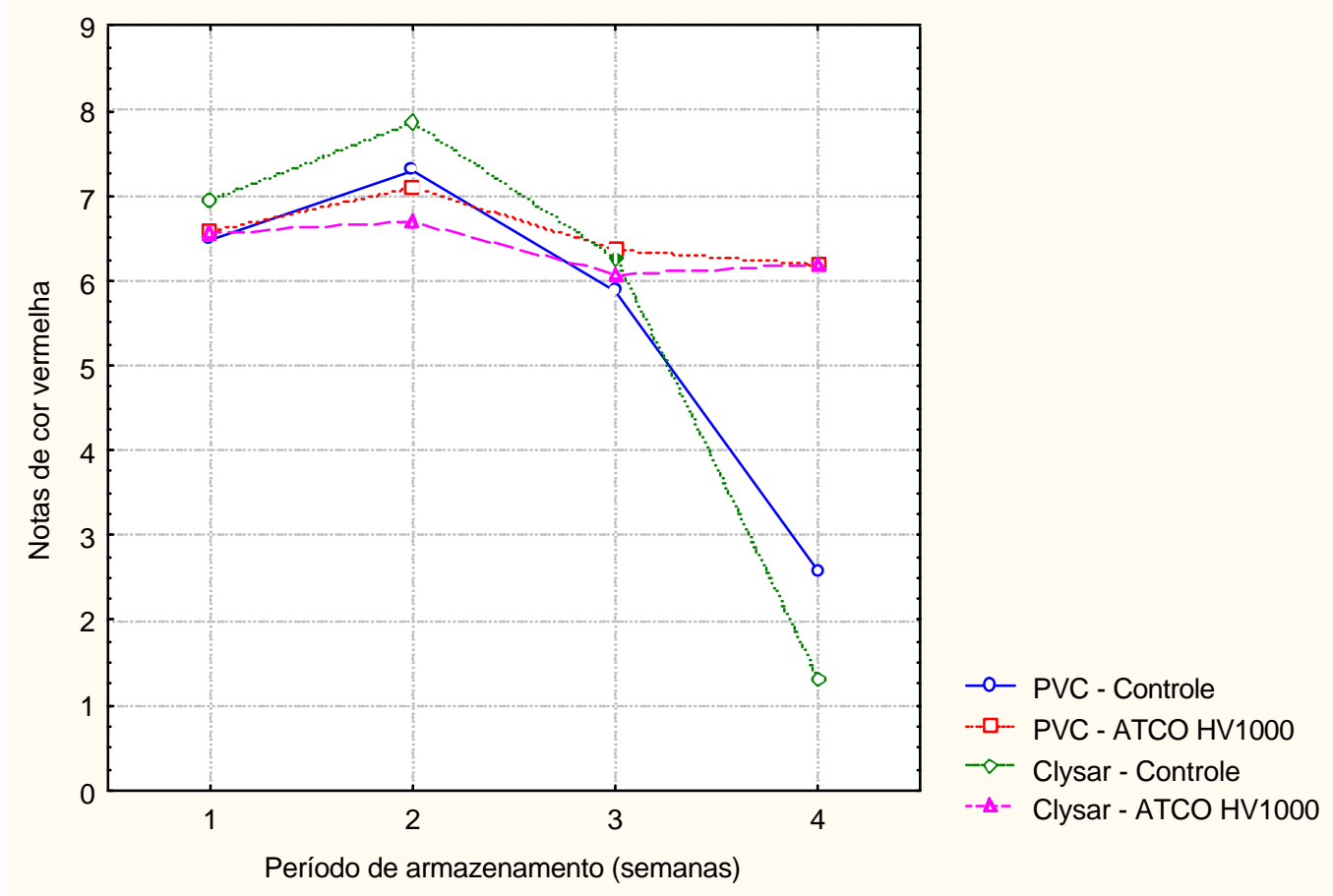

Figura 16 - Efeito do tipo de filme primário sobre a cor vermelha sensorial dos bifes de contra filé, após 1h de exposição aeróbica.

As coordenadas de luminosidade $\left(\mathrm{L}^{*}\right)$, vermelho $\left(\mathrm{a}^{*}\right)$ e amarelo $\left(\mathrm{b}^{*}\right)$ do sistema CIELAB não foram influenciadas pelo tipo de filme primário que envolvia as bandejas ao longo das $48 \mathrm{~h}$ de exposição aeróbica e até o $28^{\circ}$ dia de armazenamento. 
Comparando-se os valores de $\mathrm{L}^{*}, \mathrm{a}^{*} \mathrm{e} \mathrm{b}^{*}$ das amostras acondicionadas com ATCO HV1000 com seus respectivos controles, pode ser observado que o uso de absorvedores de oxigênio influenciou mais significativamente os valores de $a^{*}$ (Figura 17) do que das coordenadas L* (Figura 17) ou b*(Figura 19).

Os valores de $\mathrm{a}^{*}$, das amostras do acondicionadas com absorvedores foram estatisticamente superiores $(\mathrm{p}=0,000)$ do que aqueles das amostras acondicionadas sem absorvedores ao longo de todo período de armazenamento. Essa variação está associada com um aumento na taxa de reoxigenação que pode ser explicada pela diminuição de consumo de $\mathrm{O}_{2}$ pelo músculo.

Nas amostras do tratamento controle, os pigmentos superficiais oxidaram-se rapidamente e os bifes apresentaram frações de manchas de cor amarronzadas que aumentaram ao longo do tempo de armazenamento, devido ao teor residual de $\mathrm{O}_{2}$ presente nas embalagens masterpack que não continham absorvedores de oxigênio.

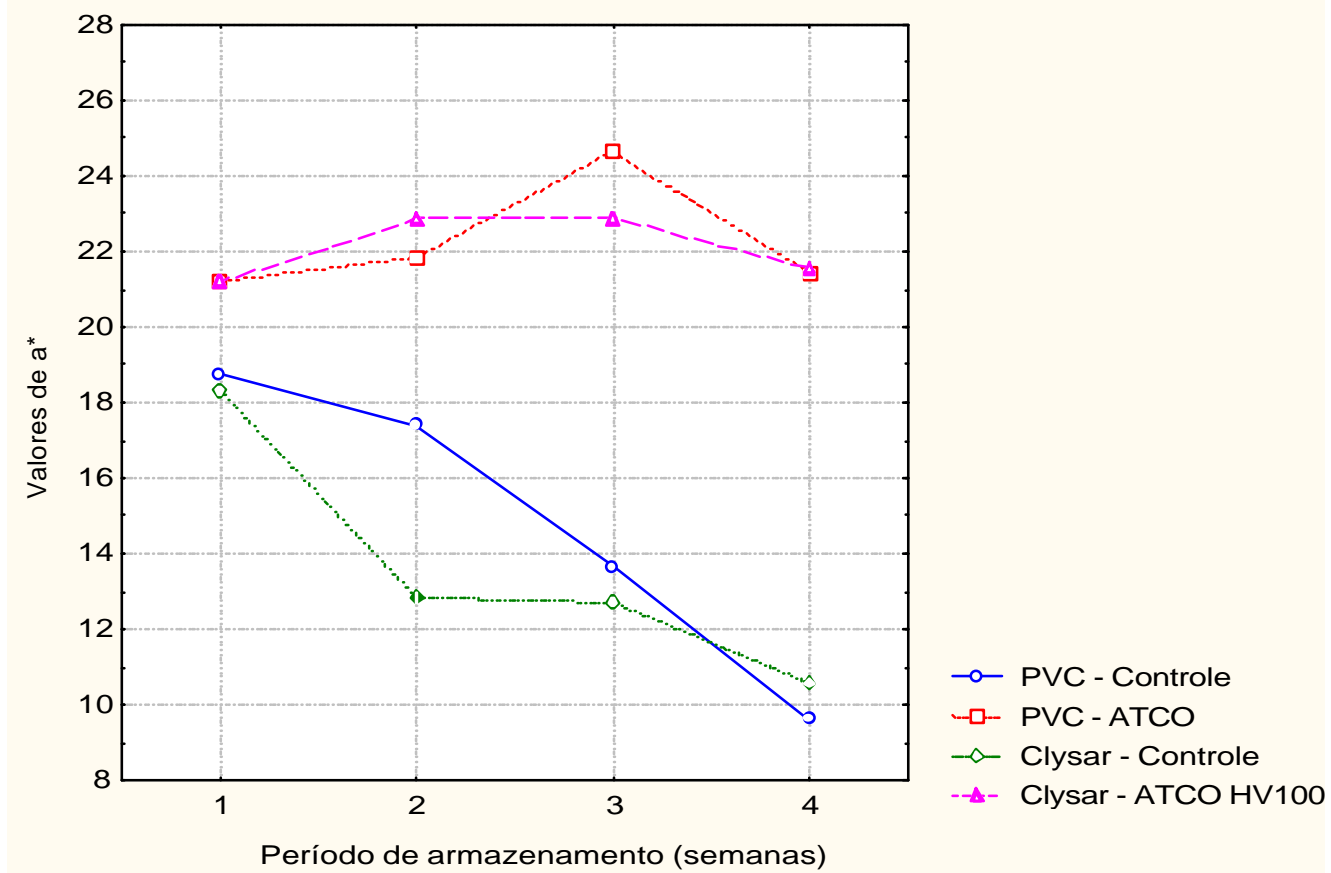

Figura 17 - Efeito do tipo de filme primário sobre a cor vermelha instrumental (a*) dos bifes de contra filé, após 1h de exposição aeróbica. 


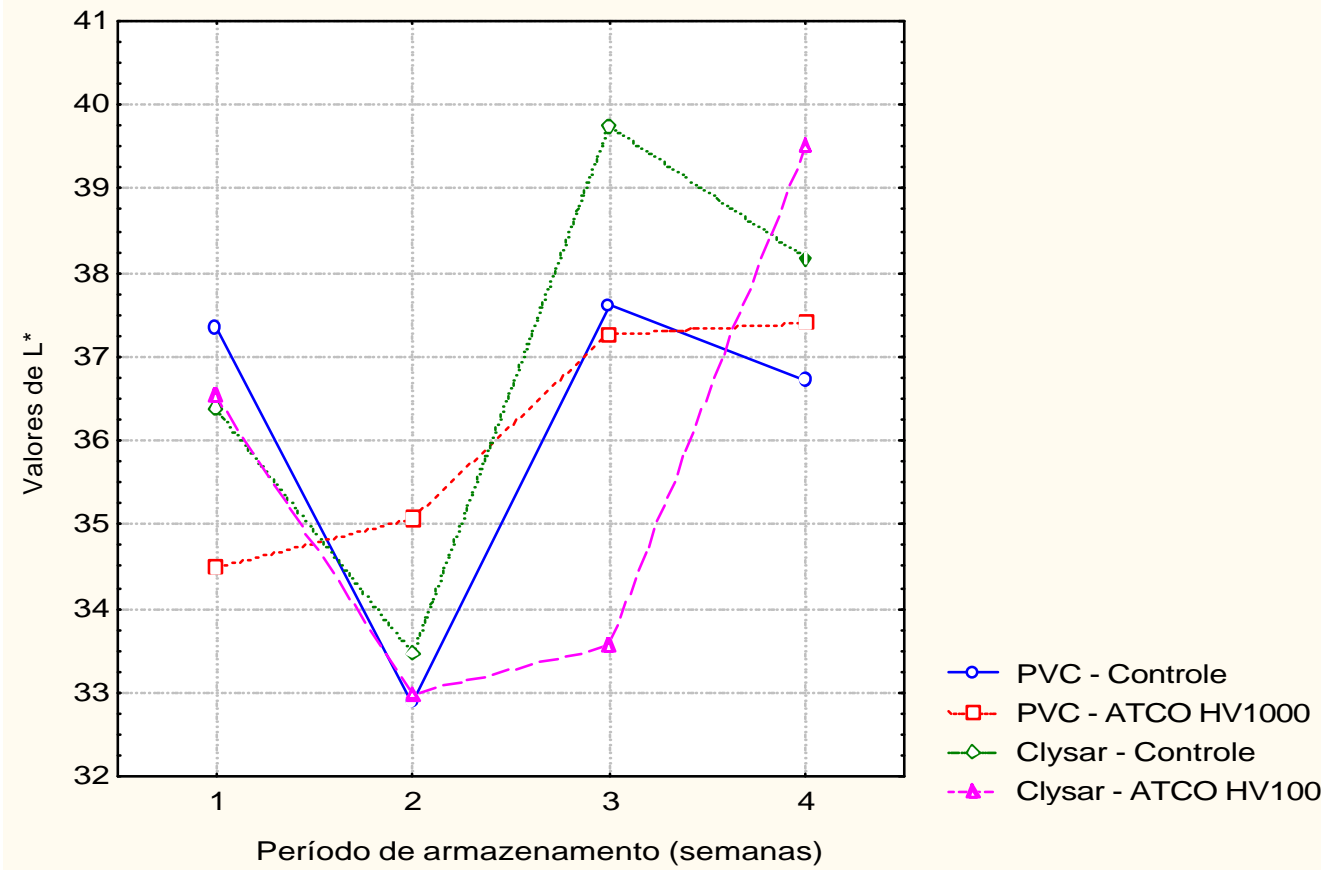

Figura 18 - Efeito do tipo de filme sobre a luminosidade $\left(\mathrm{L}^{*}\right)$ dos bifes de contra filé, após 1h de exposição aeróbica.

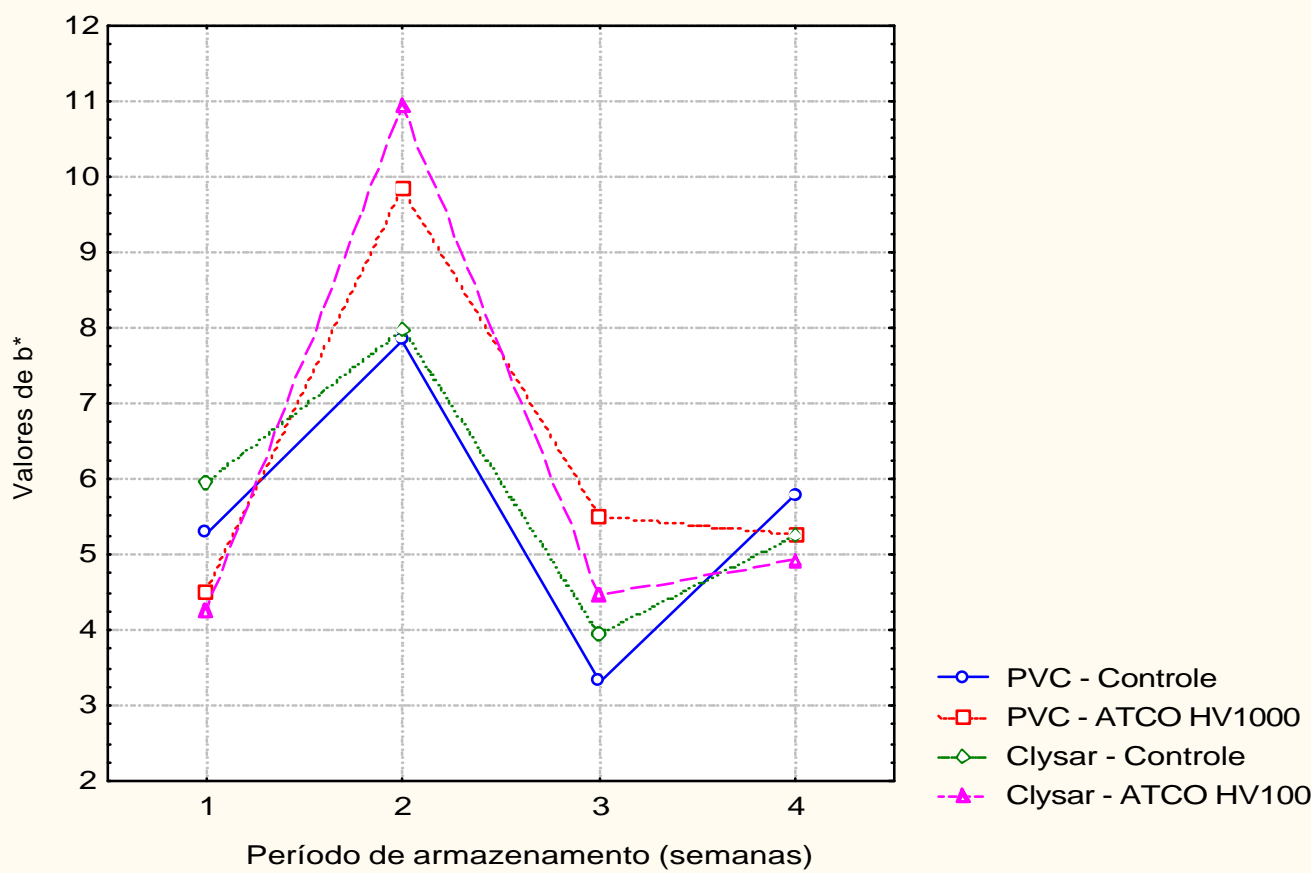

Figura 19 - Efeito do tipo de filme sobre os valores de $b^{*}$ dos bifes de contra filé, após 1h de exposição aeróbica. 
Observando-se as Figuras 20 e 21 podemos notar que uso de absorvedores ATCO HV1000 evitou a formação de manchas (<15\%), e influenciou positivamente sobre a cor rosa da gordura que recebeu notas entre 4 e 7 .

No entanto, a vida útil das amostras foi limitada pela alta contagem de bactérias psicrotróficas aeróbias ( $\left.>10^{6} \mathrm{UFC} / \mathrm{g}\right)$ a partir do sétimo dia de armazenamento sob $\mathrm{CO}_{2}$.

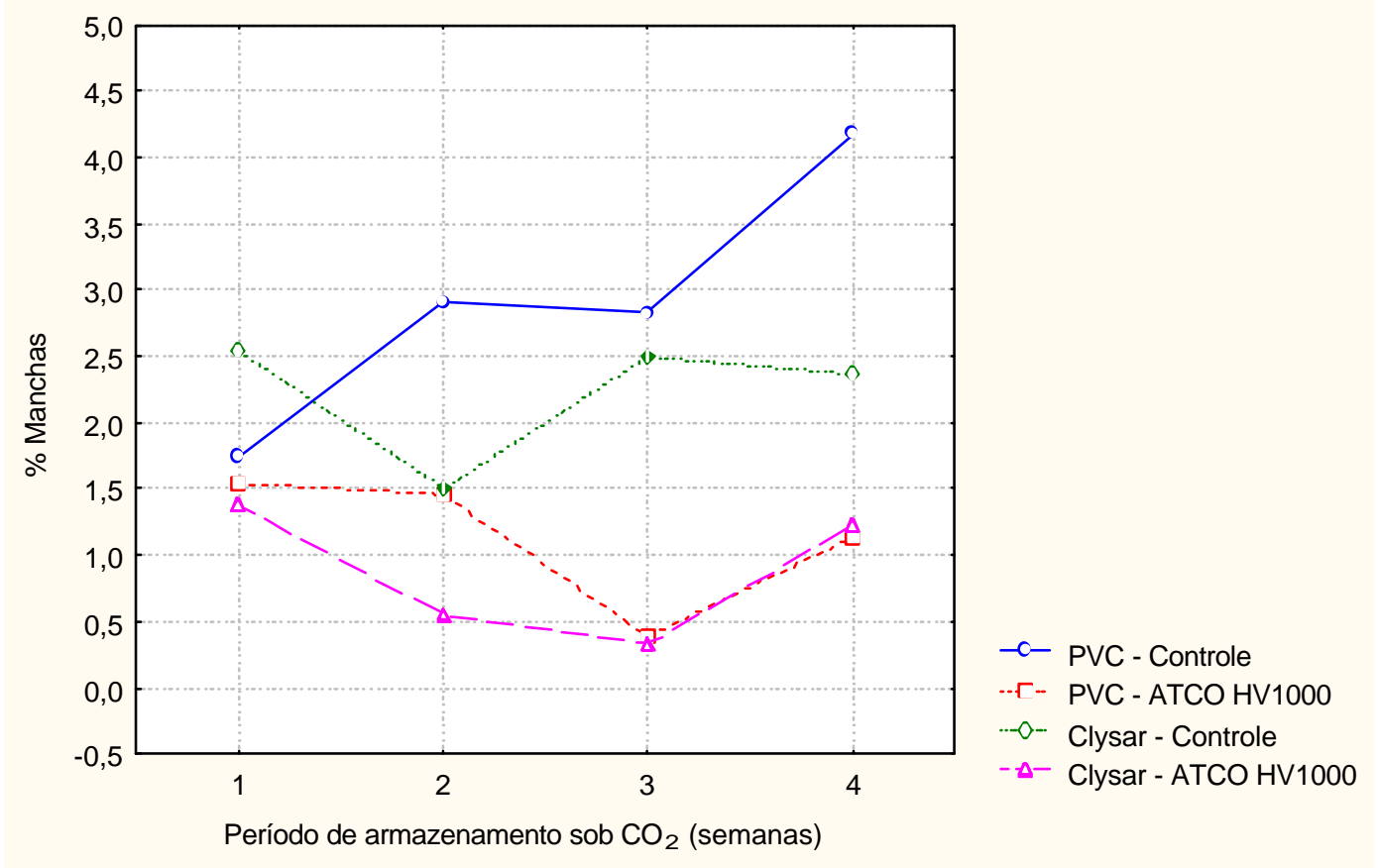

Figura 20 - Efeito do tipo de filme primário sobre a porcentagem de manchas nos bifes de contra filé, após 1h de exposição aeróbica. 


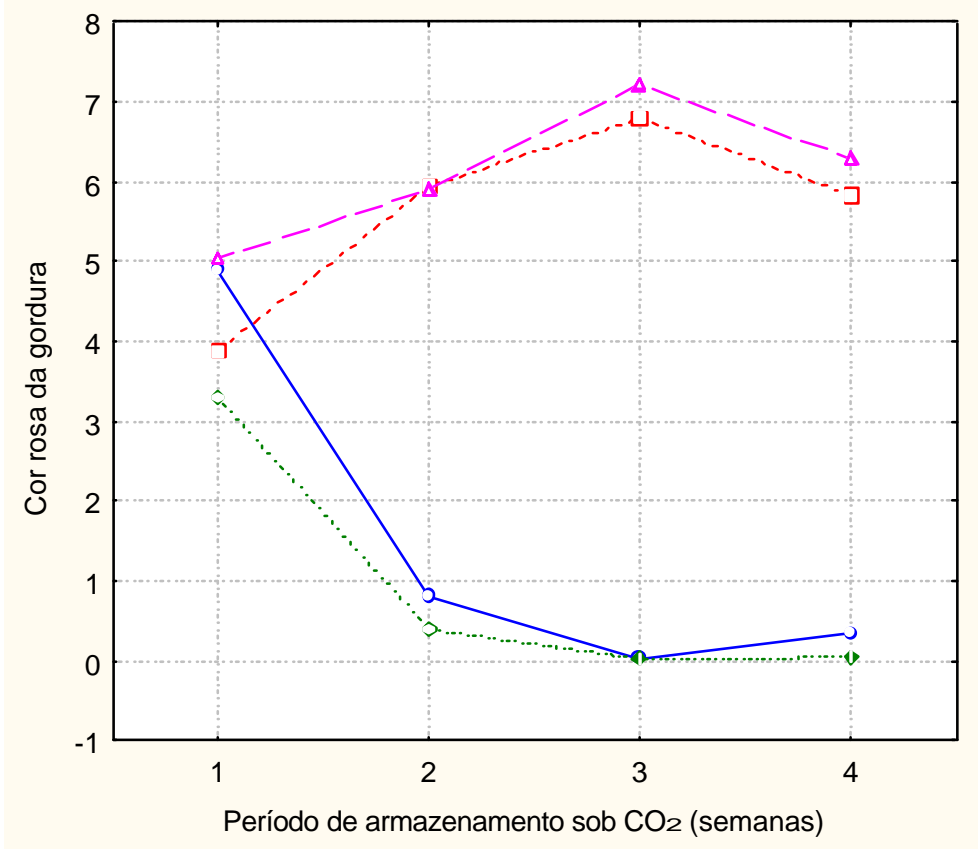

$\rightarrow$ PVC - Controle

-.L.. PVC - ATCO HV1000

-... Clysar - Controle

$-\Delta-$ Clysar - ATCO HV1000

Figura 21 - Efeito do tipo de filme primário sobre a cor rosa da gordura dos bifes de contra filé, após 1h de exposição aeróbica.

\subsubsection{Alcatra}

A cor vermelha sensorial dos bifes de alcatra não foi influenciada pelo tipo de filme primário ao longo do tempo de armazenamento sob $\mathrm{CO}_{2}$ (Figura 22).

As notas de cor vermelha subjetiva das amostras armazenadas com absorvedores de oxigênio e envoltas com filme Clysar variaram entre 6.46 e 7,47, enquanto que as notas de cor vermelha subjetiva das amostras envoltas com PVC variaram entre 6,21 e 7,85, e aproximaram-se da nota associada à cor vermelha típica de carne fresca $(7,0)$, ancorado por uma paleta do livro de Munsell. 

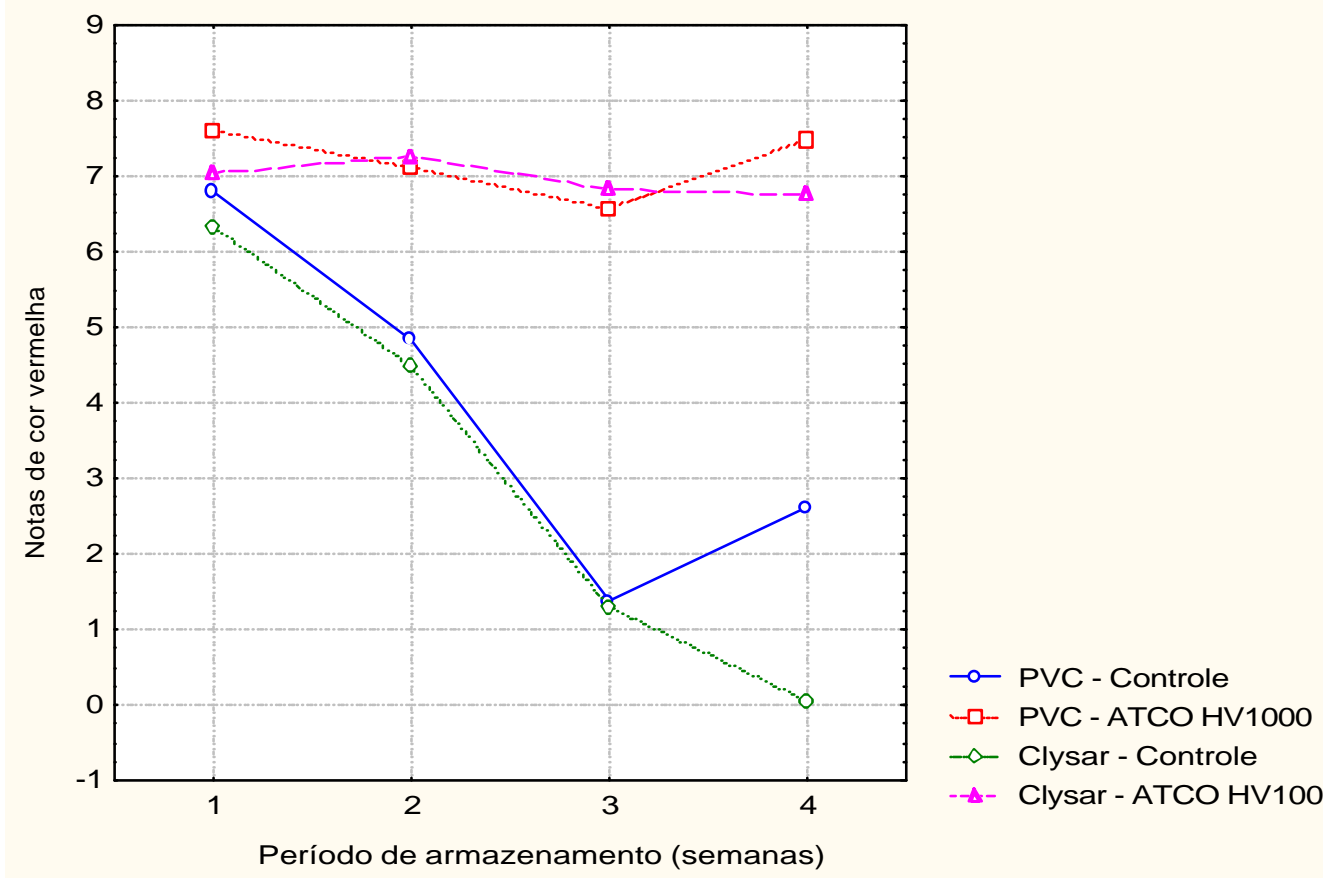

Figura 22 - Efeito do tipo de filme primário sobre a cor vermelha sensorial dos bifes de alcatra, após 1h de exposição aeróbica.

As coordenadas de $a^{*}\left(\right.$ Figura 23), L*(Figura 24) e $b^{*}$ (Figura 25) dos bifes de alcatra não foram influenciadas pelo tipo de filme primário ao longo do tempo de armazenamento sob $\mathrm{CO}_{2}$ e da exposição ao ar.

Os valores de vermelho objetivo das amostras armazenadas com absorvedores de oxigênio e envoltas com Clysar variaram de 16,11 a 23,27, enquanto que as o valor de $\mathrm{a}^{*}$ das amostras envoltas com PVC variaram entre 19,24 e 24,34.

A cor vermelha sensorial dos bifes de contra filé acondicionados com ATCO HV1000 foi estatisticamente superior à cor exibida pelos bifes dos tratamentos controle $(\mathrm{p}=0,000)$, que não readquiriram a cor vermelha após exposição aeróbica, em nenhum dos períodos avaliados. 


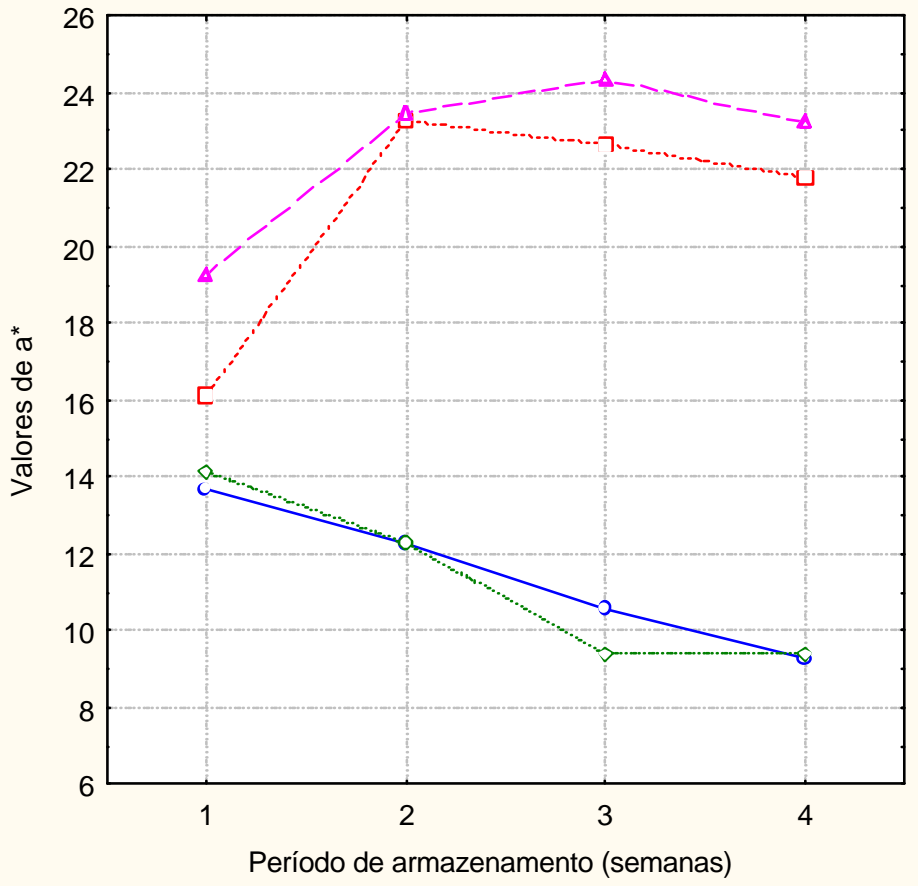

$$
\begin{array}{ll}
- & \text { PVC - Controle } \\
-\rightarrow & \text { PVC - ATCO HV1000 } \\
\rightarrow- & \text { Clysar - Controle } \\
-\triangle- & \text { Clysar - ATCO HV1000 }
\end{array}
$$

Figura 23 - Efeito do tipo de filme primário sobre a cor vermelha instrumental $\left(\mathrm{a}^{*}\right)$ dos bifes de alcatra, após $1 \mathrm{~h}$ de exposição aeróbica.

Os valores de luminosidade $\left(\mathrm{L}^{*}\right)$ e de amarelo $\left(\mathrm{b}^{*}\right)$ dos bifes de alcatra foram mais influenciados pelo tempo de armazenamento do que pelo uso de absorvedores de oxigênio. 

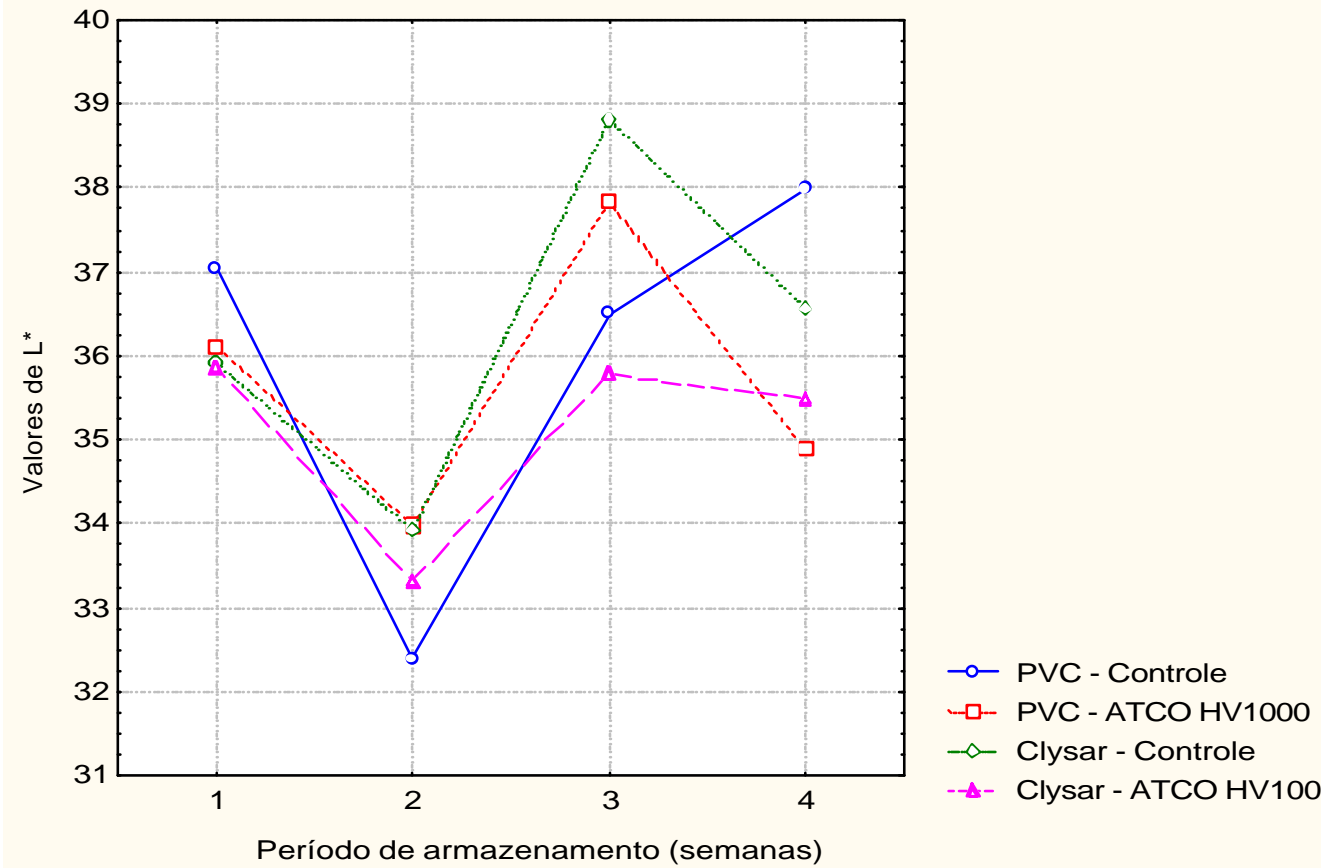

Figura 24 - Efeito do tipo de filme primário sobre a luminosidade (L*) dos bifes de alcatra, após 1h de exposição aeróbica.
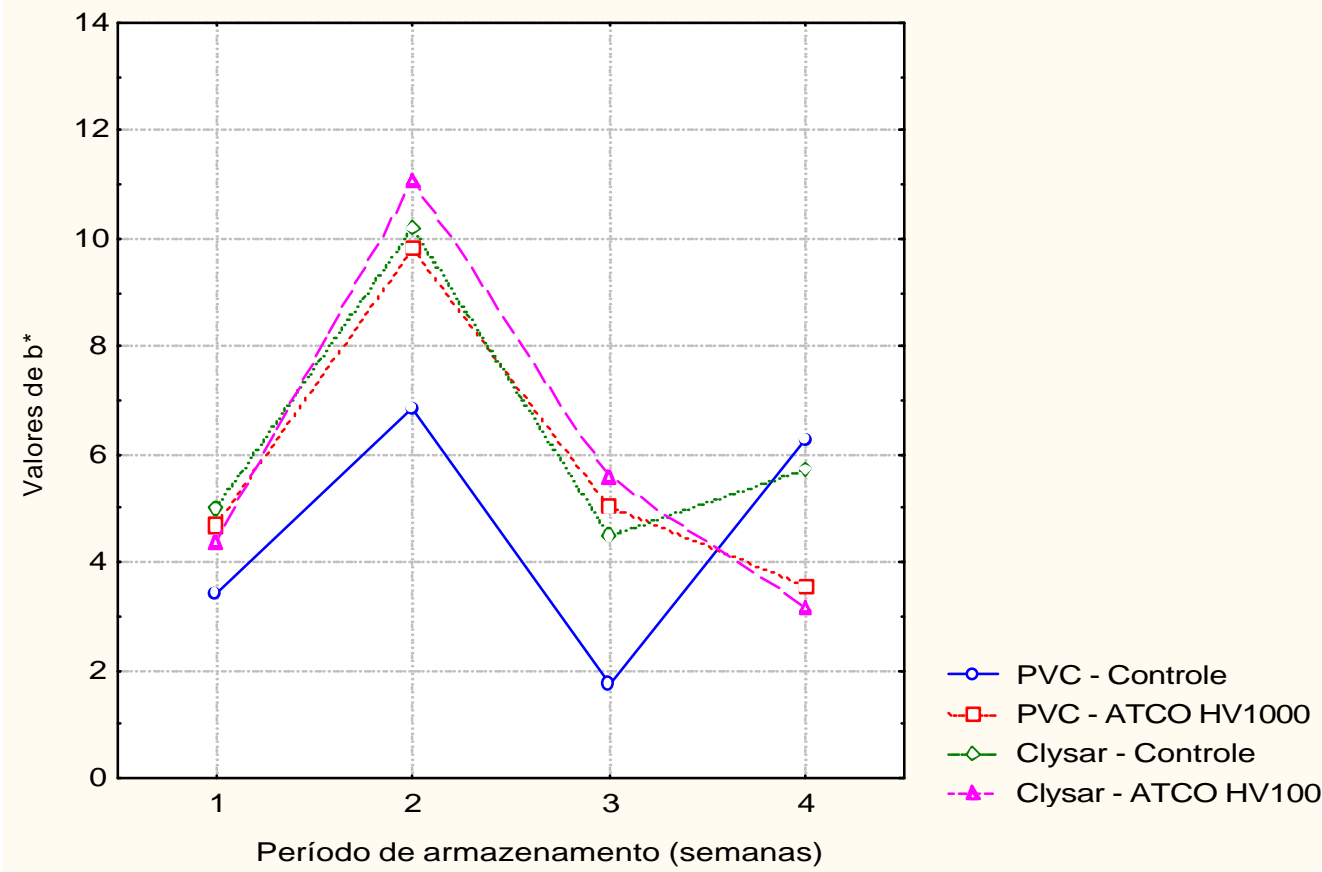

Figura 25 - Efeito do tipo de filme sobre o valor de $b^{*}$ dos bifes de alcatra, após $1 \mathrm{~h}$ de exposição aeróbica. 
O tipo de filme primário não influenciou a porcentagem de manchas (Figura 26) e nem a intensidade da cor rosa da gordura (Figura 27).

As maiores frações de manchas nas amostras acondicionadas com absorvedor de oxigênio foram observadas na primeira e na quarta semana de armazenamento (5 - 15\%) e as menores frações (até 5\%) na segunda e terceira semana de armazenamento sob $\mathrm{CO}_{2}$.

A cor rosa da gordura aumentou no decorrer do tempo e foi mais intensa nas amostras acondicionadas com absorvedor de oxigênio.

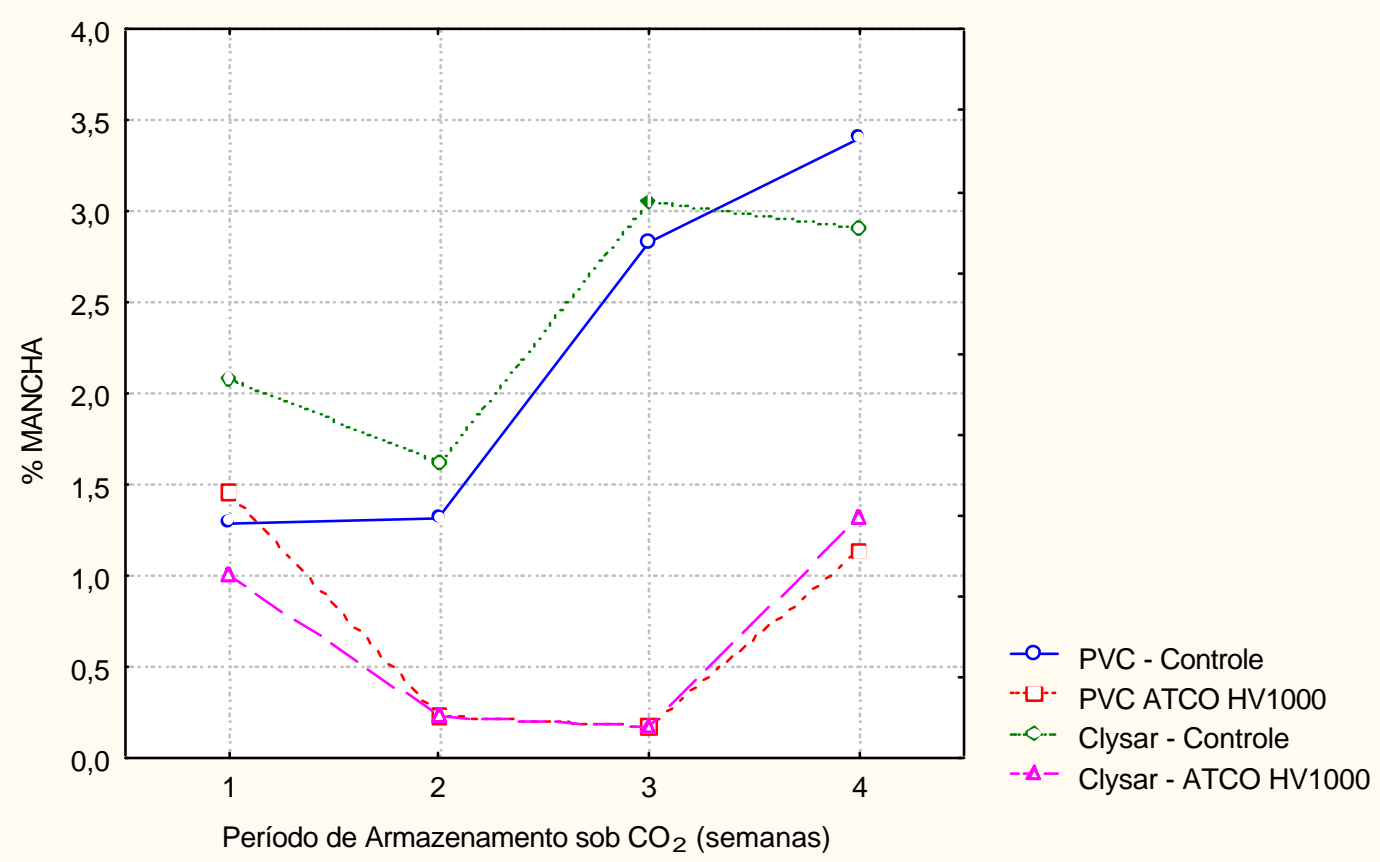

Figura 26 - Efeito do tipo de filme primário sobre a porcentagem de manchas nos bifes de contra filé, após 1h de exposição aeróbica. 


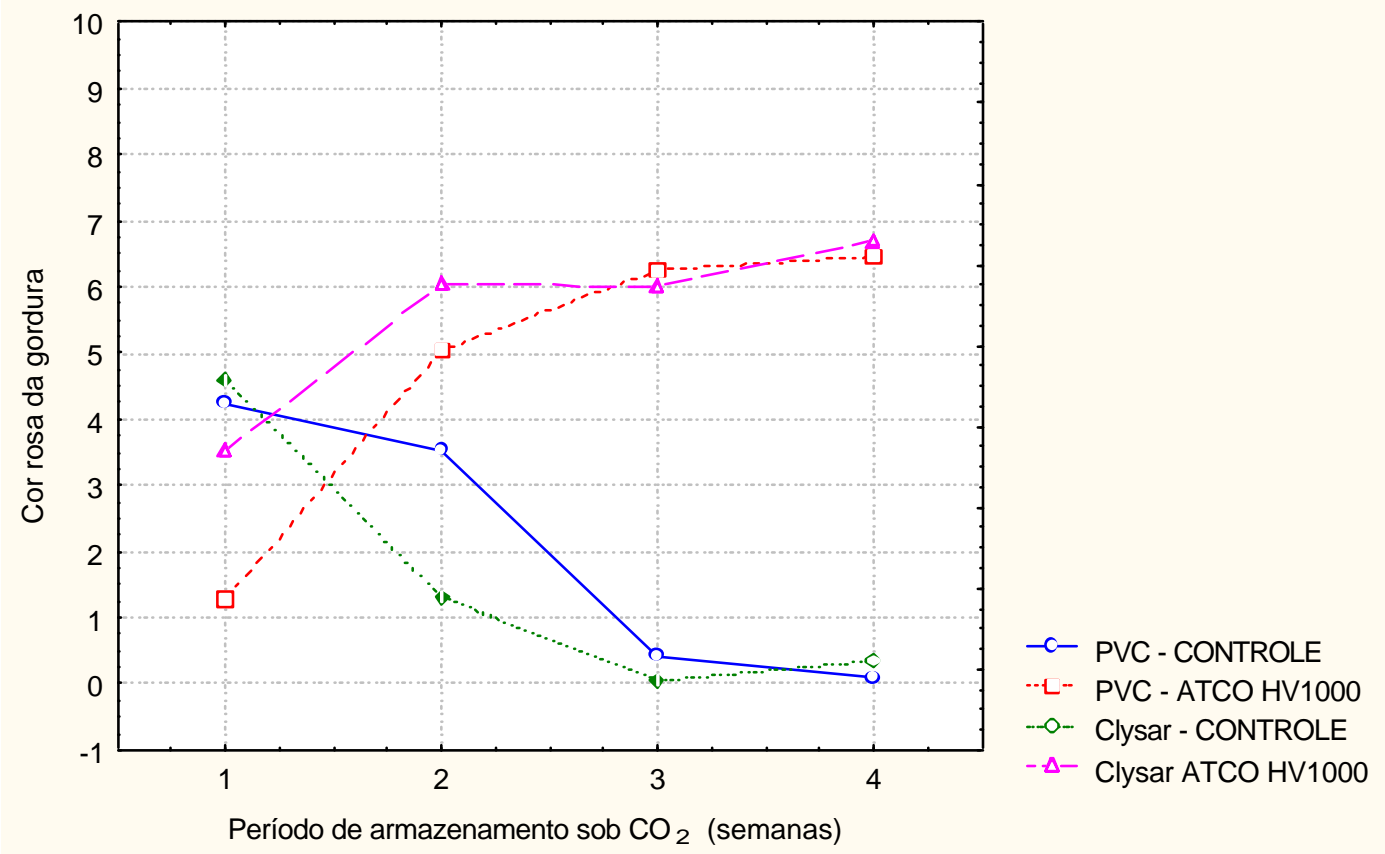

Figura 27 - Efeito do tipo de filme primário sobre a cor rosa da gordura dos bifes de alcatra, após 1h de exposição aeróbica 


\subsection{Teste Final}

\subsubsection{Avaliação do oxigênio residual nas embalagens masterpack}

O aumento do teor residual médio nas embalagens masterpack nos primeiros dias de armazenamento sob $\mathrm{CO}_{2}$ parece ser inevitável, a despeito do uso de absorvedores de oxigênio (Figura 28).
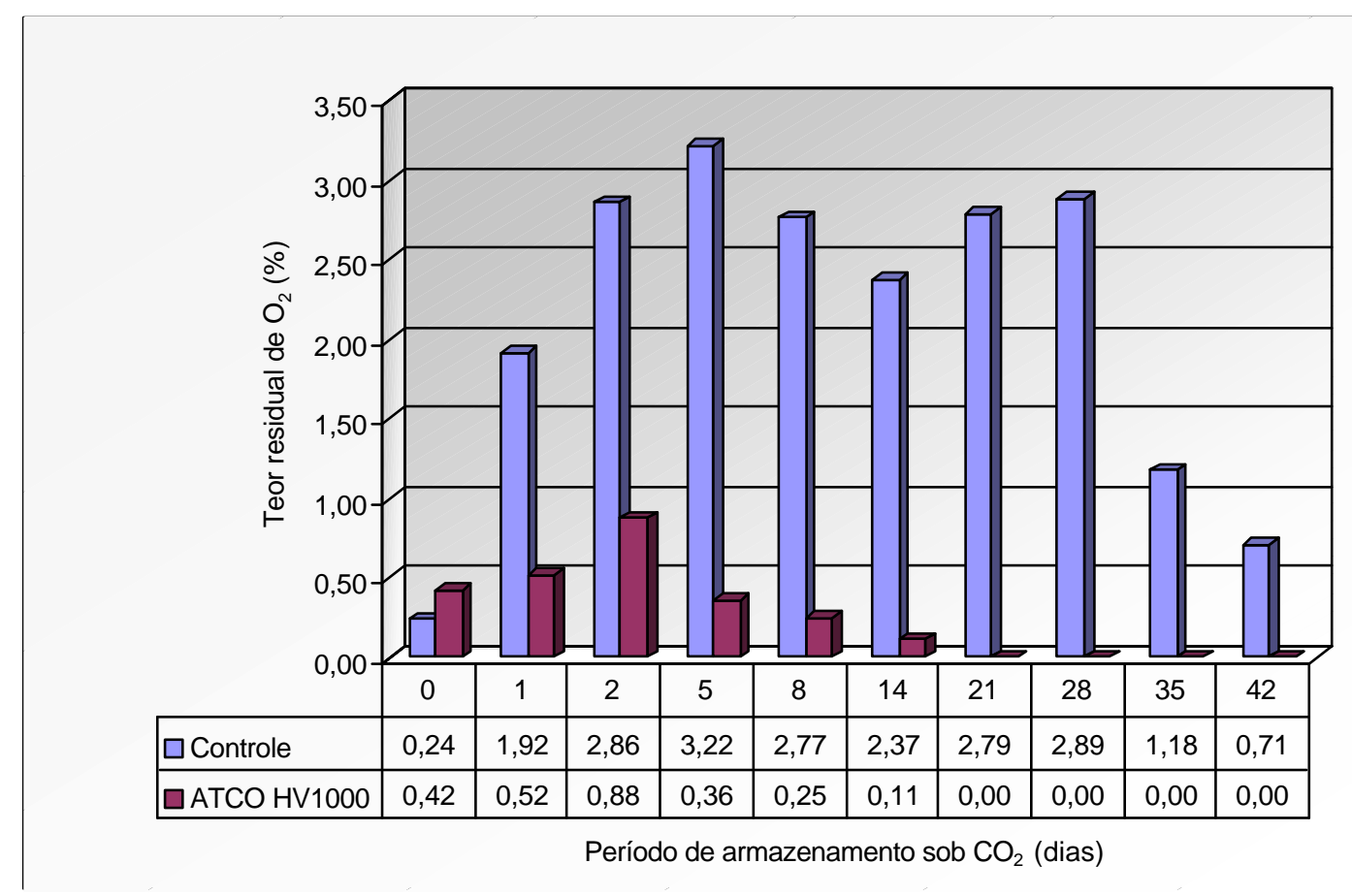

Figura 28 - Teor residual de oxigênio de oxigênio no masterpack, durante armazenamento a $1 \pm 1^{\circ} \mathrm{C}$.

Esse aumento pode ser atribuído a traços de ar atmosférico presente no gás injetado ou ocluso no absorvedor de líquido, nos cantos da bandeja, no interior da bandeja de poliestireno expandido, entre os bifes, ou ainda sob o filme primário que envolve as bandejas (Tewari et. al., 2001). Segundo Gill (1996), nenhum equipamento disponível comercialmente é capaz de evacuar todo o ar presente em uma embalagem projetada para conter atmosfera livre de oxigênio (Gill, 1996). 
Quando um absorvedor de oxigênio ATCO HV1000 foi colocado no interior das embalagens masterpack, o residual de oxigênio atingiu 0,00\% durante a terceira semana de armazenamento. $\mathrm{O}$ residual de oxigênio presente nas embalagens que não continham absorvedores de oxigênio aumentou de 0,24 a 3,22\% até o quinto dia de armazenamento, permaneceu praticamente constante e próxima a $2,5 \%$ entre o $8^{\circ}$ e o $28^{\circ}$ dia, e declinou até $0,71 \%$ no $42^{\circ}$ dia de armazenamento.

\subsection{2 $\mathrm{pH}$}

As variações de $\mathrm{pH}$ não foram associadas ao uso de absorvedores de oxigênio. De um modo geral, observou-se valores de $\mathrm{pH}$ pouco mais elevados na porção externa (superficial) dos bifes em relação aos da porção interna (Figuras 29 e 30)

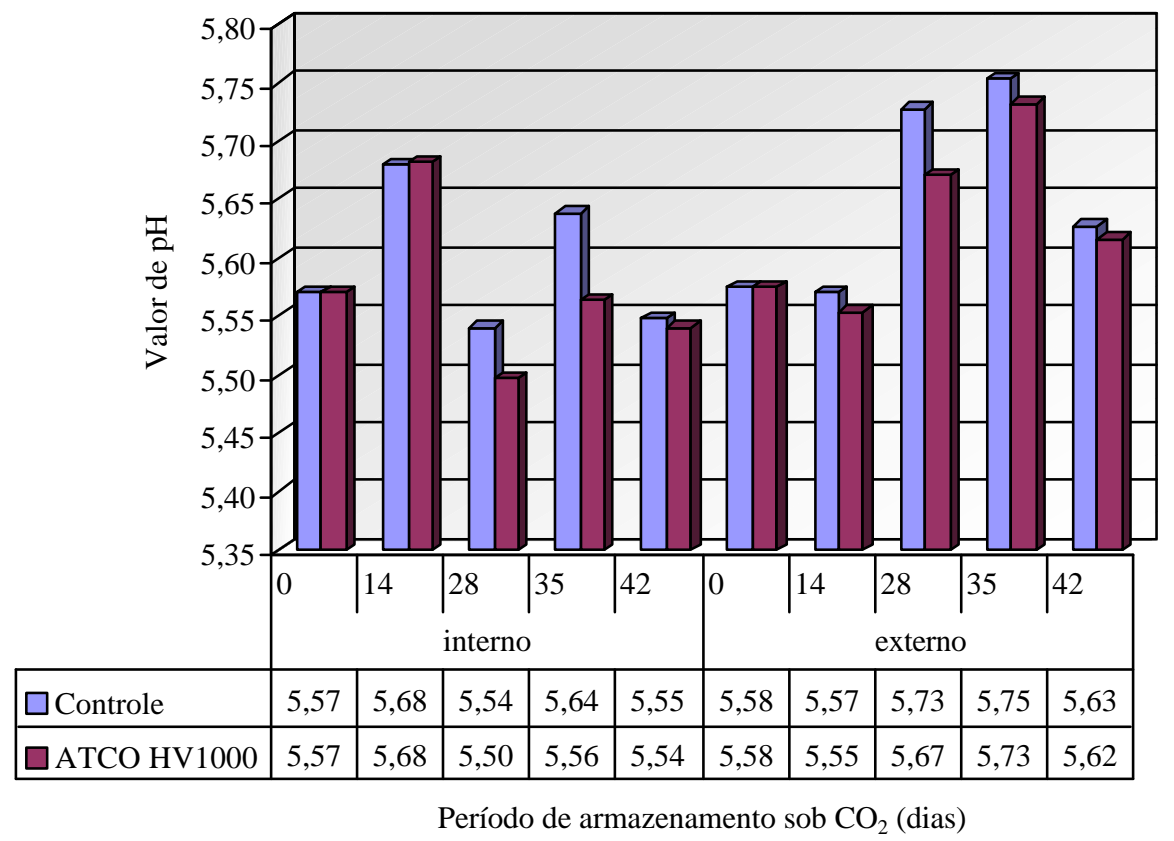

Figura 29 - Valores médios de $\mathrm{pH}$ interno e externo dos bifes de contra filé em função do tempo de armazenamento. 


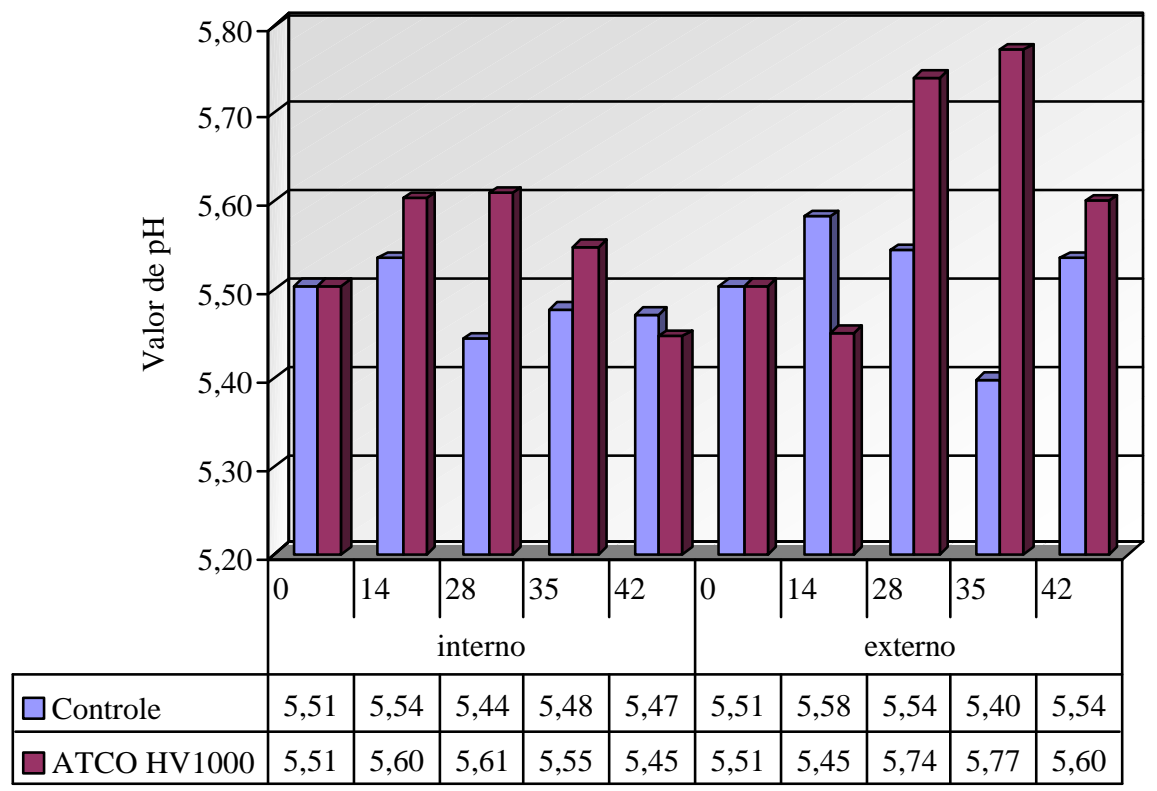

Período de armazenamento sob $\mathrm{CO}_{2}$ (dias)

Figura 30 - Valores médios de pH interno e externo dos bifes de alcatra em função do tempo de armazenamento.

Ao longo dos 42 dias de armazenamento, a variação média dos valores de $\mathrm{pH}$ interno e externo dos bifes de contra filé armazenados com absorvedores de oxigênio foi 5,50-5,68 e 5,44-5,61. Nos bifes de alcatra foi de 5,44-5,61 e 5,45-5,77, respectivamente.

Alguns valores individuais de $\mathrm{pH}$ interno e externo, das regiões caudal e cranial de um dos músculos de contra filé do Frigorífico Angeleli, de um total de quatorze músculos, apresentava a condição DFD (dark, firm and dry), ou seja, foi proveniente de animal abatido em condição de estresse $(\mathrm{pH}>5,8)$. Os músculos de alcatra apresentaram sempre $\mathrm{pH}$ normal $(\mathrm{pH}<5,8)$, independentemente do frigorífico.

Segundo Rousset \& Renerre (1991) o $\mathrm{CO}_{2}$ favorece a queda do $\mathrm{pH}$, melhora as características de cor, e simultaneamente retarda o crescimento de bactérias deterioradoras da carne com $\mathrm{pH}$ elevado $(\mathrm{pH}>5,8)$, nas mesmas condições de segurança da carne com $\mathrm{pH}$ normal. 


\subsubsection{Avaliação microbiológica}

$\mathrm{Na}$ Tabela 17 podemos observar que a matéria-prima encontrava-se em boas condições microbiológicas. Os cortes de alcatra e contra filé apresentaram baixas contagens de microrganismos deteriorantes e patogênicos, o que nos permite predizer uma vida útil mais longa.

Tabela 17. Caracterização microbiológica da matéria-prima do teste final*.

\begin{tabular}{lccc}
\hline Microrganismos & \multicolumn{2}{c}{ Resultados log UFC/g } & $\begin{array}{c}\text { Padrões da legislação } \\
\log \text { UFC/g }\end{array}$ \\
\hline Coliformes Totais & Alcatra & Contra-filé & \\
Coliformes Fecais & $\geq 1,29$ & $\geq 1,34$ & n.c \\
Mesófilos aeróbios & 0,71 & 0,92 & $2,5^{(\mathrm{b})}$ \\
S.aureus & 4,15 & 3,52 & $6,5^{(\mathrm{b})}$ \\
Salmonella sp & $<2,0$ & $<2,0$ & n.c. \\
Psicotróficas aeróbias & Ausência & Ausência & Ausência \\
Psicotróficas anaeróbias & 4,53 & 3,89 & n.c \\
Bactérias Láticas & 4,11 & 3,05 & n.c \\
Clostridium Sulfito Redutor & 3,85 & 3,16 & n.c \\
\hline
\end{tabular}

Z: Valor estimado, detectado pela maior diluição utilizada.

<: Valor estimado, detectado pela menor diluição utilizada.

n.c.: nada consta

(a): Resolução- $\operatorname{RDCn}^{\circ} 12$-Regimento Técnico sobre padrões microbiológicos para alimentos-Anvisa/MS- 02/01/2001.

(b): Código Sanitário - Secretaria de vigilância Sanitária do Estado de São Paulo Decreto $n^{\circ} 12.342$ de 27/08/78 
Até o $28^{\circ}$ dia de armazenamento, o crescimento de psicrotróficos aeróbios nos bifes de contra filé (Figura 31) e alcatra (Figura 32) foi mais influenciado pelo efeito bacteriostático do $\mathrm{CO}_{2}$, do que pelo uso de absorvedores de oxigênio.

De modo geral, o número de bactérias psicrotróficas aeróbias que recobriam os bifes de contra filé e alcatra armazenados com absorvedores de oxigênio manteve-se ligeiramente inferior em relação ao encontrado nas amostras do tratamento controle, ao longo das 48h de exposição aeróbica dos primeiros 28 dias de armazenamento. Este número foi um pouco mais acentuado nos períodos subseqüentes.

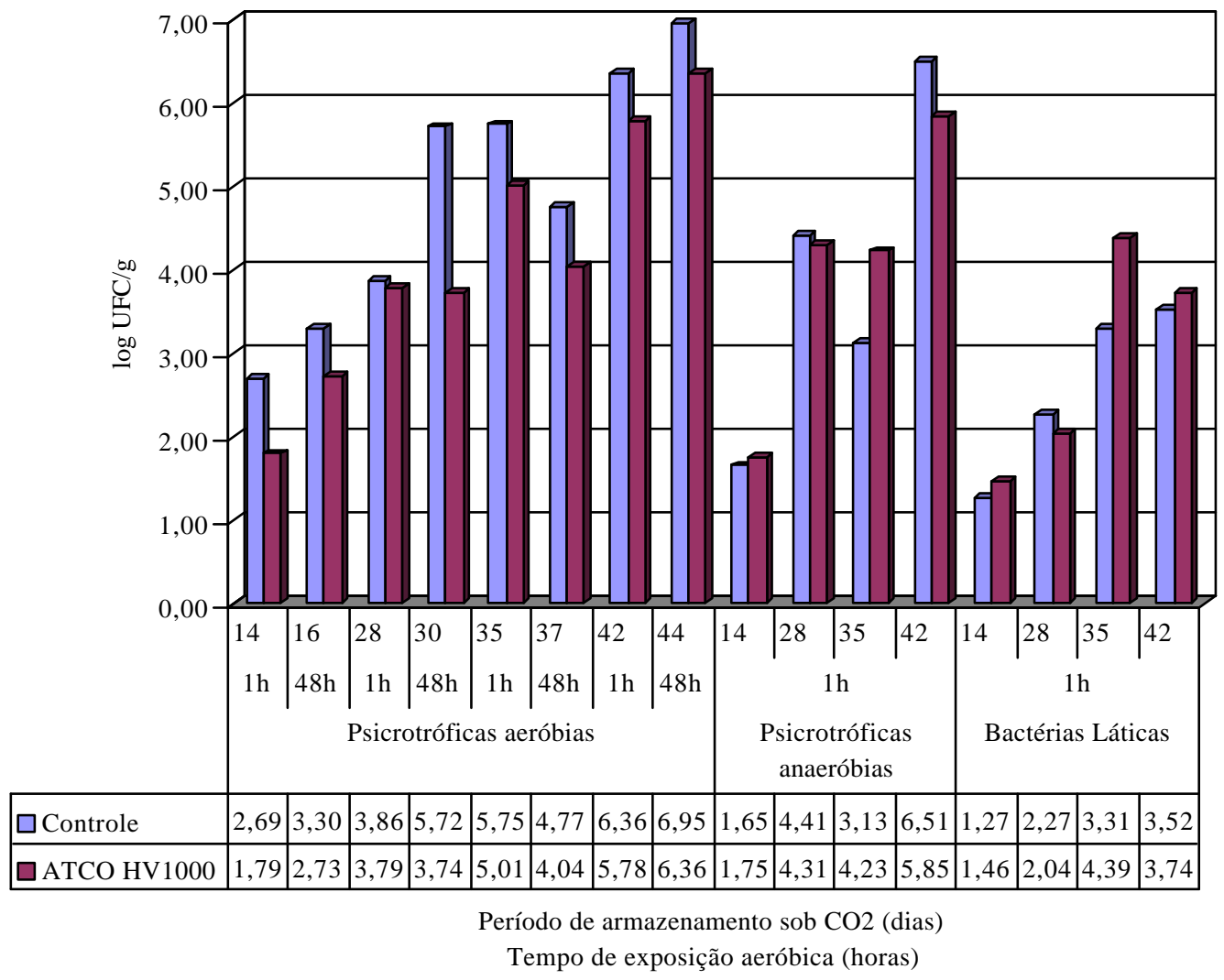

Figura 31 - Contagem de bactérias psicrotróficas aeróbias, psicrotróficas anaeróbias e láticas nos bifes de contra filé. 
Houve um expressivo crescimento de microrganismos psicrotróficos aeróbios nos produtos, principalmente a partir do $35^{\circ}$ dia de armazenamento.

$\mathrm{Na}$ contagem de bactérias psicrotróficas aeróbias, muito provavelmente, foram enumerados certos tipos de mesófilos que predominavam na microbiota inicial, além de psicrotróficos estritamente aeróbios.

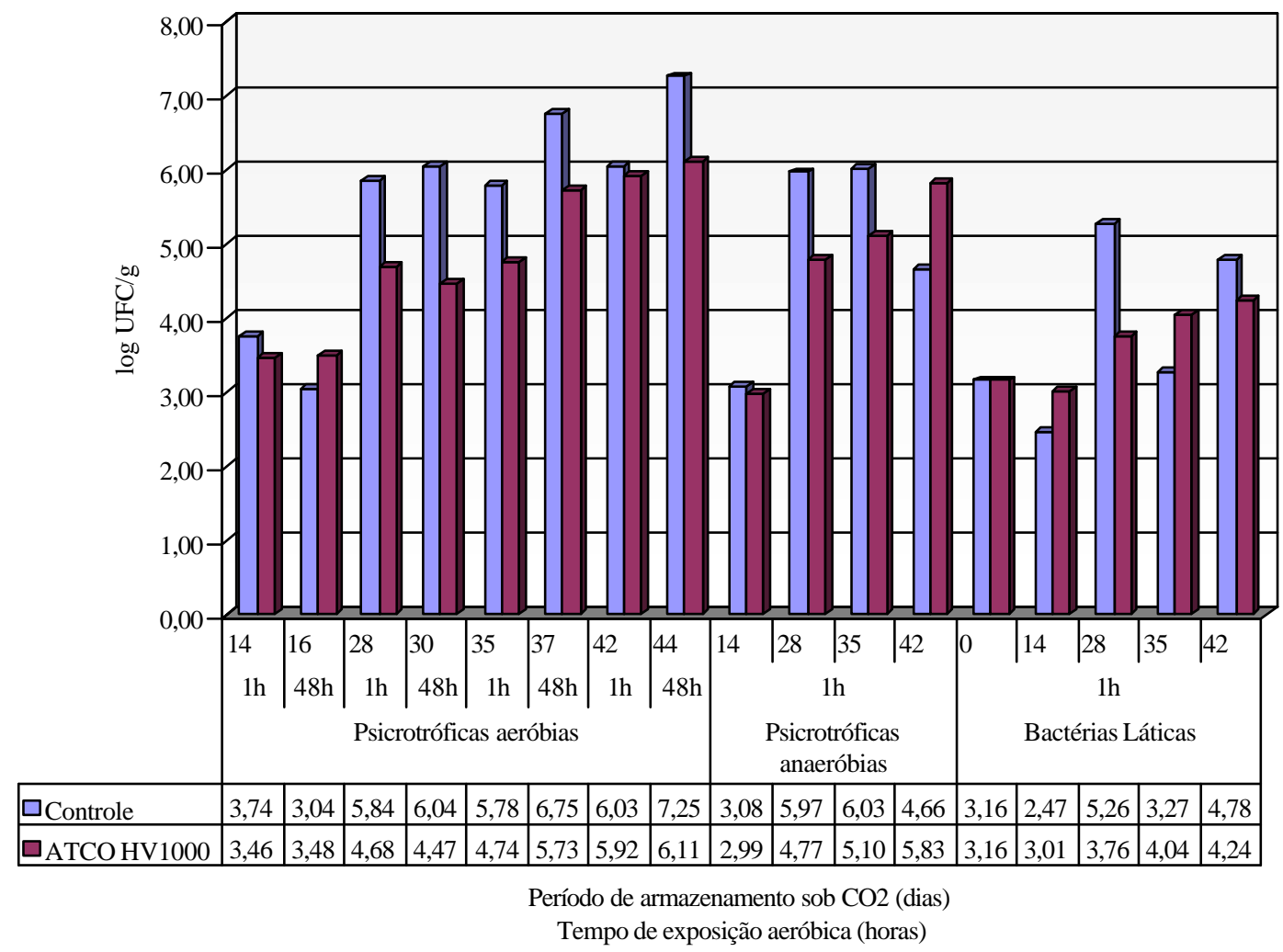

Figura 32 - Contagem de bactérias psicrotróficas aeróbias, psicrotróficas anaeróbias e láticas nos bifes de alcatra após 1h e 48h de exposição aeróbica.

Quando as contagens de psicrotróficos aeróbios da matéria-prima (Tabela 17) são comparadas com as contagens obtidas no $28^{\circ}$ dia de armazenamento, é possível observar uma fase de adaptação desses microrganismos, tanto nos bifes de contra filé como também nos bifes de alcatra, acondicionados com ou sem absorvedores de oxigênio, indicando o efeito bacteriostático do $\mathrm{CO}_{2}$ em ambos os tratamentos. 
Segundo Seideman \& Durland (1984), atmosferas com dióxido de carbono puro são mais eficientes na seleção de bactérias láticas, se aplicado antes das bactérias deterioradoras se adaptarem às condições ambientais.

A contagem máxima de psicrotróficos aeróbicos nos bifes de contra filé e alcatra acondicionados com absorvedores de oxigênio ocorreu após 42 dias de armazenamento sob $\mathrm{CO}_{2}$, e foi próxima a 6,00 log UFC/g, aproximando-se da contagem máxima de psicrotróficos aeróbios do tratamento controle.

O oxigênio residual presente nas embalagens masterpack que não continham absorvedores de oxigênio e o atraso no seqüestro do oxigênio no interior das embalagens que os continham, provavelmente contribuíram para que o número de bactérias psicrotróficas aeróbias superasse a contagem de bactérias psicrotróficas anaeróbias e láticas das amostras ao longo de todos os períodos avaliados.

Por uma variedade de razões (nível de contaminação inicial, permeabilidade do filme, temperatura de armazenamento, etc.), bactérias Gram-negativas (Enterobacteriaceae e mesmo Pseudomonas spp.) podem, em algumas ocasiões, formar grandes populações em cortes de carne bovina acondicionados em atmosféricas livres de oxigênio (García-Lópes et. al., 1998).

O crescimento de bactérias psicrotróficas anaeróbias e de bactérias láticas nos bifes de contra filé e alcatra foi mais influenciado pelo tempo de armazenamento sob $\mathrm{CO}_{2}$, do que pelo uso de absorvedores de oxigênio.

Ao longo do tempo houve um aumento contínuo da contagem de psicrotróficos anaeróbios e de bactérias láticas nos cortes de contra filé e alcatra, independente do uso de absorvedores de oxigênio, devido principalmente à influência da alta concentração de $\mathrm{CO}_{2}$ durante o armazenamento.

Nas contagens de psicrotróficos anaeróbios dos cortes devem ter sido enumerados principalmente bactérias láticas, microaerófilas com baixo potencial de deterioração.

Quando a quantidade de $\mathrm{CO}_{2}$ adicionada é suficiente para saturar a carne (2-3L $\mathrm{CO}_{2} / \mathrm{kg}$ ), a microflora é gradualmente selecionada entre os microrganismos tolerantes ao 
$\mathrm{CO}_{2}$, como as bactérias láticas, principalmente Carnobacterium spp., Lactobacillus e Leuconostoc spp., que não são afetadas pelo gás (Borch et. al., 1996; Gill, 1988). Muito possivelmente, podemos correlacionar o crescimento de microrganismos psicrotróficos anaeróbios dos bifes de alcatra e contra filé armazenados sob $\mathrm{CO}_{2}$, com ou sem absorvedores de oxigênio, com o aumento do número de bactérias láticas que são microaerófilas.

\subsubsection{Avaliação sensorial}

\subsubsection{Contra filé}

Geralmente as amostras de contra filé acondicionadas sem absorvedores de oxigênio receberam notas superiores a 5,5 (Figura 33). Esses valores indicavam que a carne apresentava uma coloração vermelha mais escura, tendendo ao marrom, associada à oxidação parcial da mioglobina.

O uso de absorvedores de oxigênio influenciou significativamente a avaliação da cor sensorial após 14 dias $(p=0,000), 28$ dias $(p=0,000)$ e 35 dias $(p=0,006)$ de armazenamento. Aos 42 dias de armazenamento não houve diferença estatística entre os bifes de contra filé acondicionados com ou sem absorvedores, muito provavelmente devido à grande faixa de variação da cor vermelha. 

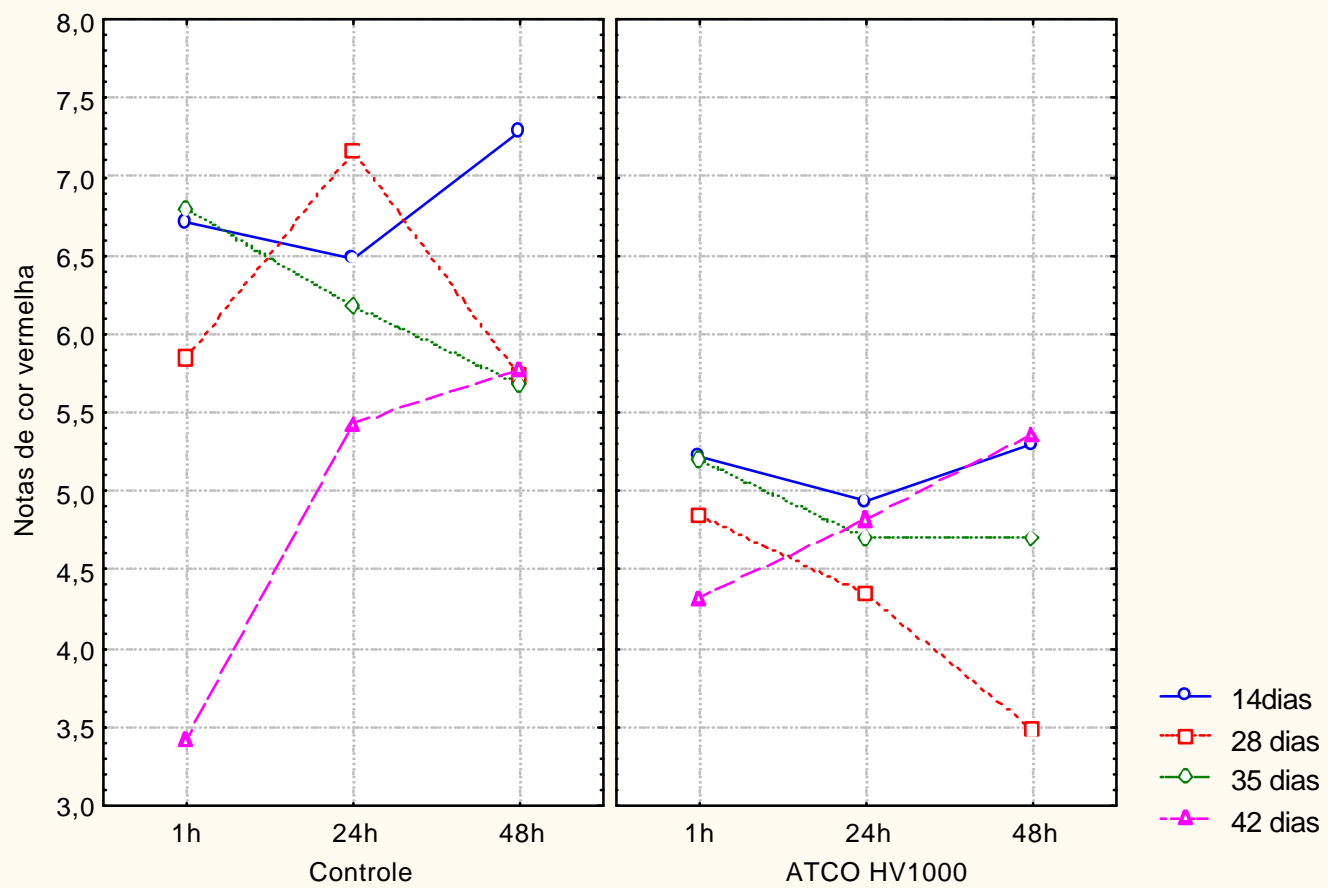

Figura 33 - Efeito do uso de absorvedores de oxigênio sobre a cor vermelha sensorial dos bifes de contra filé, após 1, 24 e 48h de exposição aeróbica.

Ao longo das $48 \mathrm{~h}$ de exposição aeróbica, as notas de cor sensorial das amostras acondicionadas com absorvedores de oxigênio não variaram estatisticamente.

Após 1h da abertura das embalagens masterpack, as notas médias da cor vermelha dos bifes de contra filé acondicionados com absorvedores de oxigênio aproximaram-se da nota atribuída pelos provadores à cor vermelha típica de carne fresca $(5,5)$, aos 14 dias (5,22), 28 dias (4,84), 35 dias (5,20) e 42 dias $(4,32)$ de armazenamento anaeróbio. Em geral, as notas de cor vermelha dessas amostras diminuíram após $24 \mathrm{~h}$ de exposição aeróbica, e apresentaram ligeiro aumento ou mantiveram-se constante, após $48 \mathrm{~h}$ de reoxigenação, com exceção do $28^{\circ}$ dia de armazenamento. Neste caso, a superfície da carne reoxigenou-se de forma não uniforme, apresentando grandes frações de áreas descoloridas, e recebeu a menor nota de todos os períodos avaliados $(3,48)$. 
O consumo de oxigênio residual presente nas embalagens que não continham absorvedores de oxigênio e a alta capacidade de redução da mioglobina pelo músculo do contra filé, paralela à oxidação parcial do pigmento, contribuíram para a percepção de manchas (frações de metamioglobina) nas amostras controle. Quando a porcentagem de manchas foi comparada, as amostras de bifes de contra filé armazenadas com ATCO HV1000 sempre apresentaram menores frações de manchas (até 5\%) do que as acondicionadas sem absorvedores de oxigênio (5-15\%). Ao longo de todos os períodos avaliados (14, 28, 35 e 42 dias), as notas da cor rosa da gordura dos bifes de contra filé acondicionados com ATCO HV1000 foram significativamente superiores à dos bifes armazenados sem absorvedores de oxigênio $(p=0,000)$.

\subsubsection{Alcatra}

A cor vermelha dos bifes de alcatra acondicionados com ATCO HV1000 foi geralmente mais escura $(>5,5)$ que a atribuída à carne fresca $(5,5)$ ao longo de todos os períodos avaliados (Figura 34).

Aos 14, 28, 35, e 42 dias de armazenamento e após 1h de exposição aeróbica, as notas médias atribuídas pelos provadores à cor vermelha dos bifes acondicionados com absorvedores de oxigênio foram respectivamente, 5,95; 5,65; 5,70 e 6,64. Essas notas não variaram estatisticamente ao longo das $48 \mathrm{~h}$ de exposição aeróbica.

Até o $14^{\circ}$ dia de armazenamento, a cor vermelha escura dos bifes acondicionados com absorvedores de oxigênio não diferiu estatisticamente da cor observada nos bifes do tratamento controle. Nesse período os bifes de alcatra armazenados com ATCO HV1000 apresentaram as maiores frações de manchas (>15\%), e menor intensidade de cor rósea na gordura $(3,10)$.

Após 28, 35 e 42 dias de armazenamento sob $\mathrm{CO}_{2}$ as amostras do tratamento controle foram julgadas completamente descoloridas e diferiram estatisticamente das notas atribuídas à cor vermelha das amostras acondicionadas com absorvedores de oxigênio $\left(p=0,000, p=0,006\right.$ e $p=0,006$, respectivamente). A partir do $28^{\circ}$ dia de 
armazenamento os bifes acondicionados com ATCO HV1000 apresentaram menores frações de manchas (até 5\%) e gordura rósea, enquanto que os bifes do tratamento controle apresentaram-se completamente descoloridos, com gordura esbranquiçada ou levemente acinzentada.

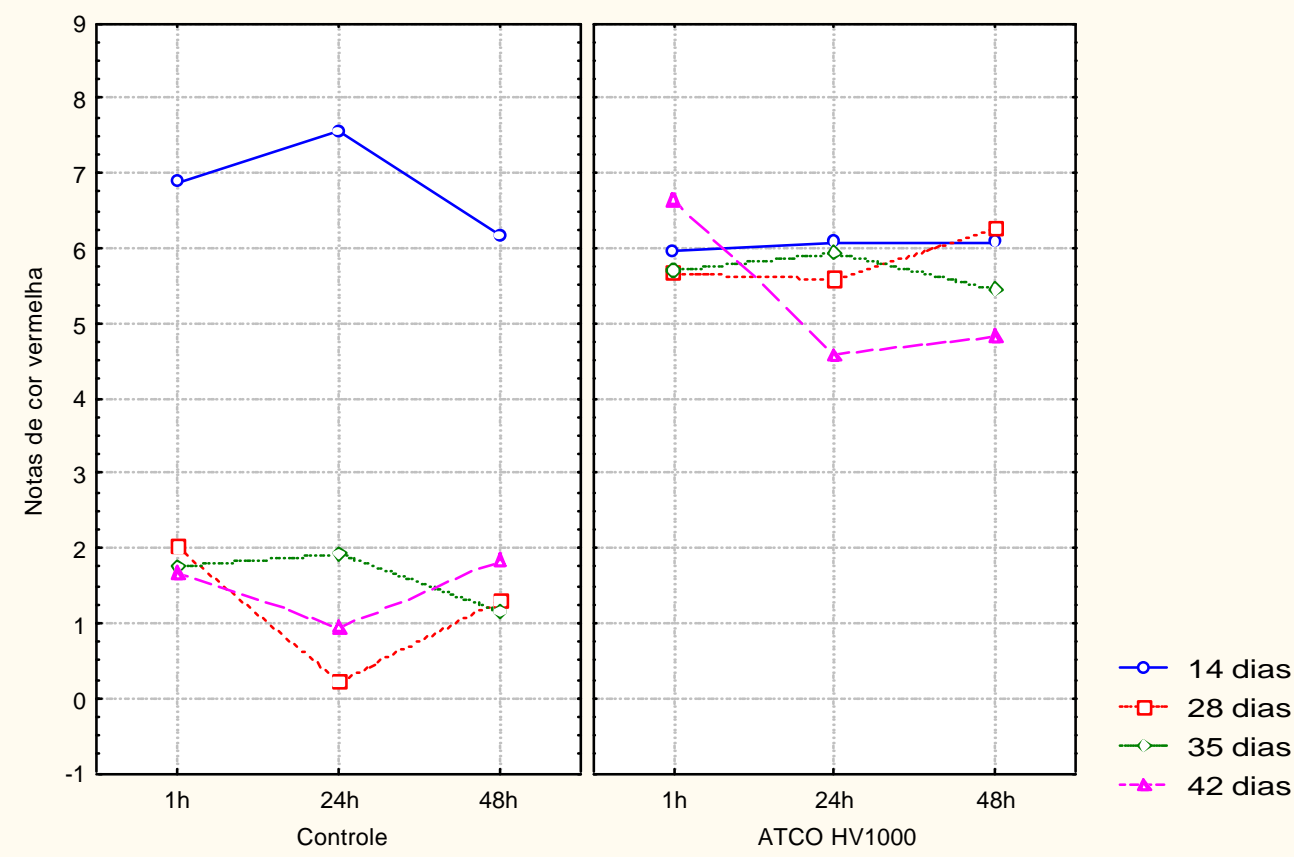

Figura 34 - Efeito do uso de absorvedores de oxigênio sobre a cor vermelha sensorial dos bifes de alcatra, após 1, 24 e 48h de exposição aeróbica.

\subsubsection{Avaliação instrumental da cor}

\subsubsection{Contra filé}

Conforme mostra a Figura 35, os valores de vermelho $\left(\mathrm{a}^{*}\right)$ das amostras de contra filé acondicionadas com absorvedores de oxigênio foram estatisticamente superiores àqueles das amostras do tratamento controle após 14, 35 e 42 dias de armazenamento ( $p=0,022 ; p=0,023 ; p=0,005$, respectivamente).

Contudo, não foi observada diferença significativa entre os dois tratamentos no $28^{\circ}$ dia de armazenamento. 
No entanto, comparando-se a proporção de oximioglobina entre as amostras acondicionadas com absorvedores de oxigênio e as do tratamento controle, medida pelo método simplificado de diferença (R630-R580), foi possível observar diferenças estatísticas em todos os períodos avaliados, incluindo o $28^{\circ}$ dia de armazenamento $(p=0,000 ; p=0,012 ; p=0,000$ e $p=0,000)$.

Aos 14, 28, 35, e 42 dias de armazenamento e após 1h de exposição aeróbica, os valores médios de vermelho dos bifes acondicionados com absorvedores de oxigênio foram de 15,96; 16,07; 17,06 e 17,54, respectivamente. Nesses mesmos períodos os valores de R630-R580 foram de 19,27; 17,72; 20,09 e 20,67.

Posteriormente, Renerre \& Mazuel (1985) observaram que quando a formação de metamioglobina compromete $20 \%$ da carne, a razão de compra entre a carne descolorida em relação à carne vermelha brilhante é de 1:2, correspondendo a valores mínimos de R630-R580 próximo a 12,5.

Os valores de $\mathrm{a}^{*}$ e da diferença de reflectância (R630-R580) não variaram estatisticamente ao longo das 48h de exposição aeróbica.

Trabalhos anteriores realizados no CTC-ITAL determinaram que o limite crítico mínimo de aceitação da cor vermelha física $\left(\mathrm{a}^{*}\right)$ situa-se em torno de $\mathrm{a}^{*}=14$.

Contudo, para Hunt (1980), esses valores são úteis somente para seleção de critérios na pesquisa onde somente a descrição da cor é necessária. A cor refletida pela carne bovina armazenada sob atmosfera modificada está diretamente relacionada com o estado químico da mioglobina.

O método da diferença de reflectância entre 630nm e 580nm (R630-R580) mede a proporção relativa de oximioglobina em relação à metamioglobina e fornece uma informação muito mais útil de como um tratamento afeta a estabilidade da cor vermelha, do que os valores de vermelho (a*) (Hunt, 1980; Strange et. al., 1974).

De fato, foi possível observar que as notas de cor vermelha correlacionaram-se melhor com o método simplificado de diferença de reflectância (R630-R580) do que os valores de vermelho $\left(\mathrm{a}^{*}\right)$. Comparando-se os coeficientes de Pearson (r) que correlacionaram as medidas sensoriais com as medidas físicas da cor vermelha, foi 
possível verificar um maior coeficiente de correlação utilizando-se o método de diferença de reflectância $(r=0,58)$, do que os valores de $\mathrm{a}^{*}(r=-0,39)$.
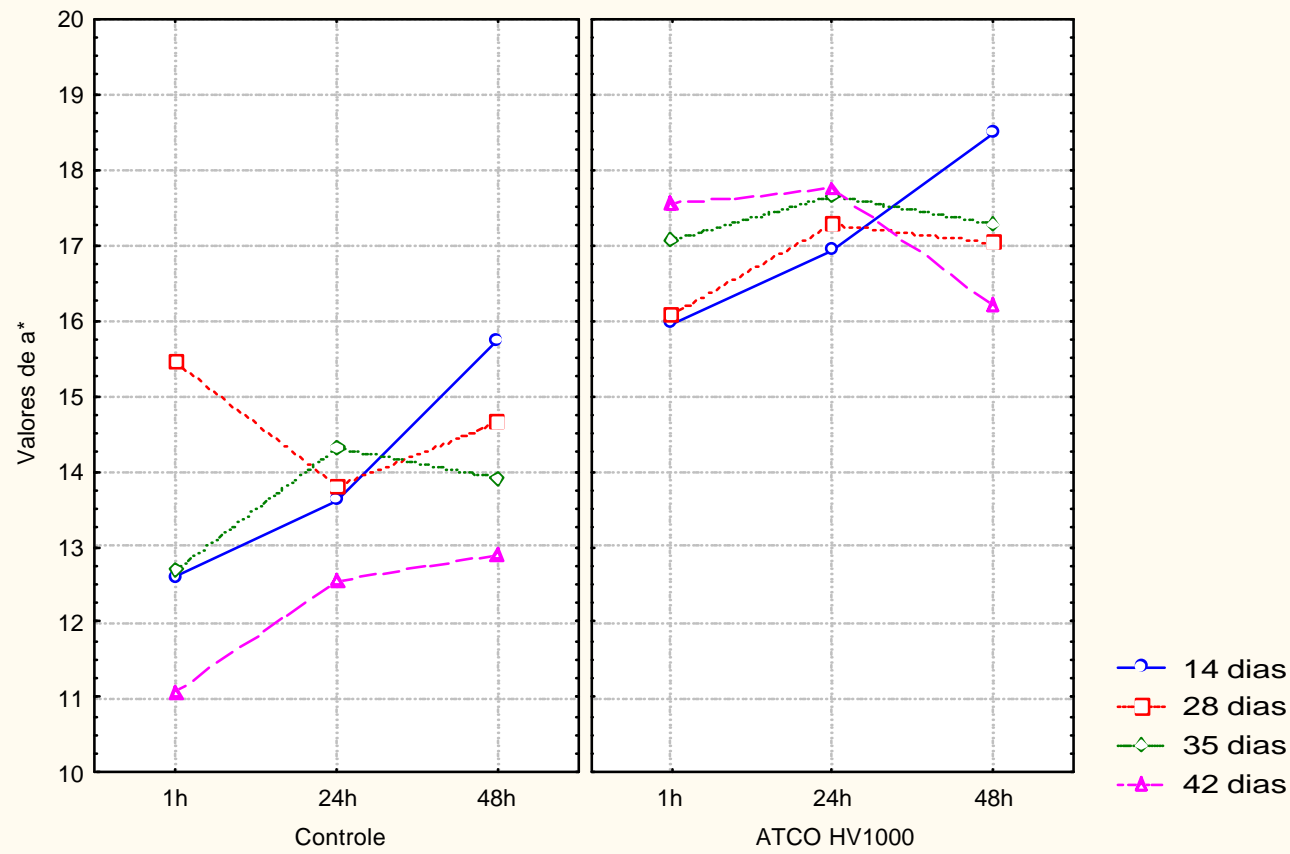

Figura 35 - Efeito do uso de absorvedores de oxigênio sobre a cor vermelha instrumental dos bifes de contra filé, após 1, 24 e 48h de exposição aeróbica.

A Figura 36 mostra os valores de $\mathrm{L}^{*}$ (luminosidade) refletidos pelas amostras dos diferentes tratamentos ao longo de todos os períodos avaliados. Após 14, 28, 35 e 42 dias de armazenamento e $1 \mathrm{~h}$ de exposição aeróbica, os valores médios de $\mathrm{L}^{*}$ (luminosidade) dos bifes de contra filé armazenados com ATCO HV1000 foram de 38,28; 36,79; 37,64 e 39,00, respectivamente. Esses valores não diferiram significativamente ao longo das $48 \mathrm{~h}$ de exposição aeróbica e foram estatisticamente superiores aos valores do tratamento controle somente no último período avaliado $(p=0,018)$. 

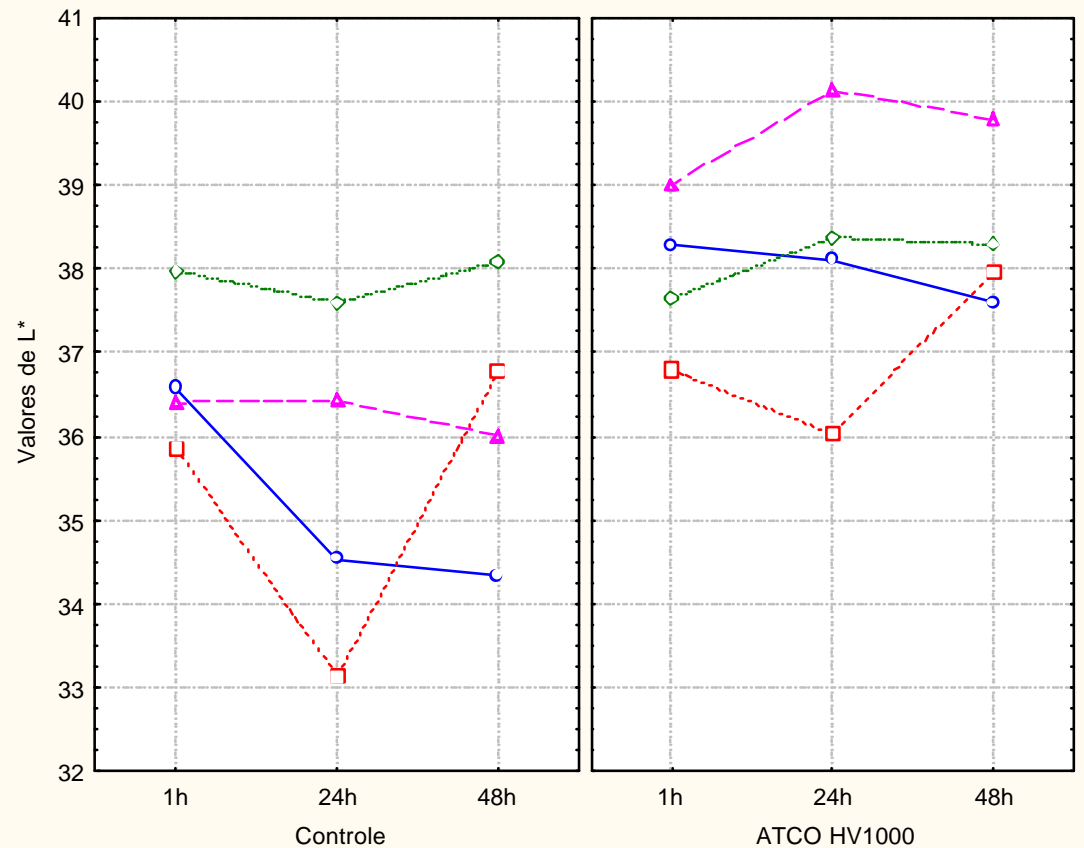

-14 dias

-.- 28 dias

- 35 dias

$-\Delta-42$ dias

Figura 36 - Efeito do uso de absorvedores de oxigênio sobre os valores de $\mathrm{L}^{*}$ dos bifes de contra filé, após 1, 24 e 48h de exposição aeróbica.

Os valores de $b^{*}$ das amostras acondicionadas com absorvedores de oxigênio não diferiram estatisticamente daqueles das amostras do tratamento controle (Figura 37). 

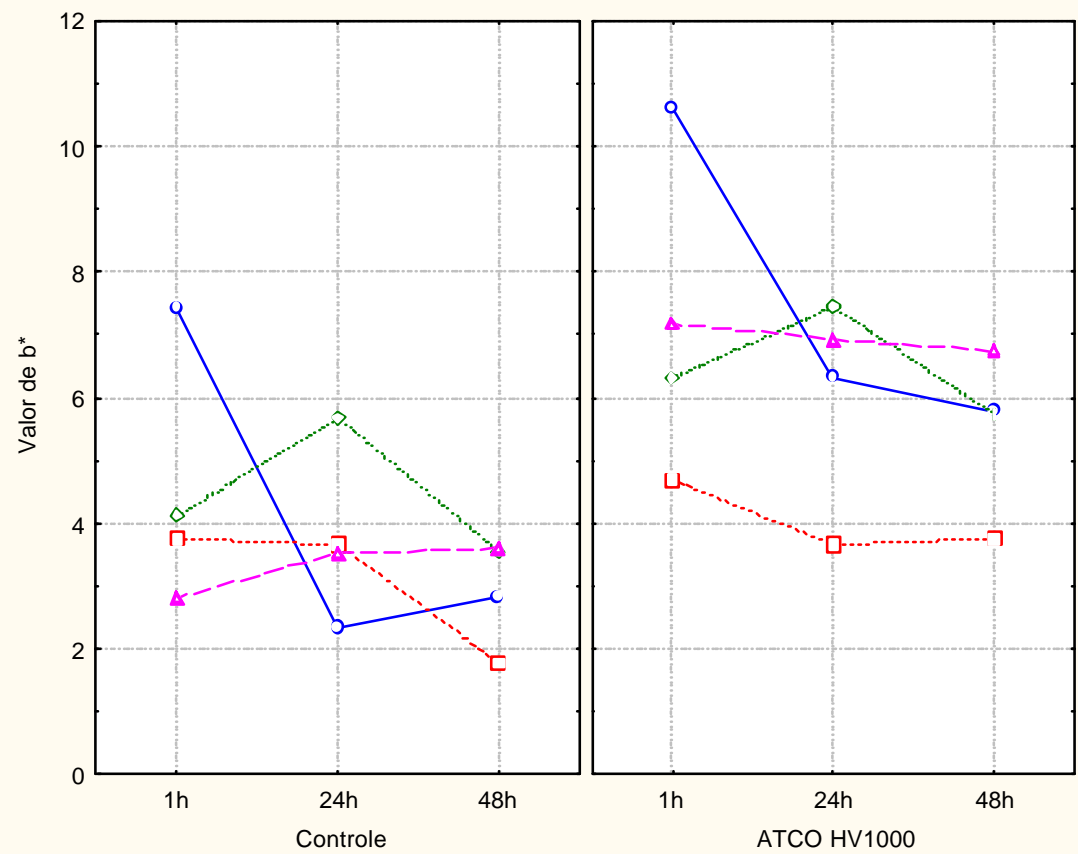

-14 dias
---28 dias
$-\sim 35$ dias
$-\triangle-42$ dias

Figura 37- Efeito do uso de absorvedores de oxigênio sobre os valores de $b^{*}$ dos bifes de contra filé, após 1, 24 e 48h de exposição aeróbica.

\subsubsection{Alcatra}

O uso de absorvedores de oxigênio no acondicionamento das amostras de alcatra mostrou um efeito positivo sobre os valores de vermelho (a*) (Figura 38) e a estabilidade da oximioglobina, obtidos instrumentalmente. Isto indica que o seqüestro do oxigênio residual pelos absorvedores de oxigênio favoreceu a reoxigenação e a reaquisição da cor vermelha após exposição aeróbica.

Os bifes do tratamento controle, que não foram acondicionados com absorvedores de oxigênio, exibiram uma coloração superficial acinzentada após exposição aeróbica, ao longo dos 42 dias de armazenamento.

Comparativamente, os valores de $\mathrm{a}^{*}$ dos bifes de alcatra acondicionados com ATCO HV1000 foram estatisticamente superiores aos das amostras do tratamento controle, que apresentavam descoloridos $(p=0,000)$. 

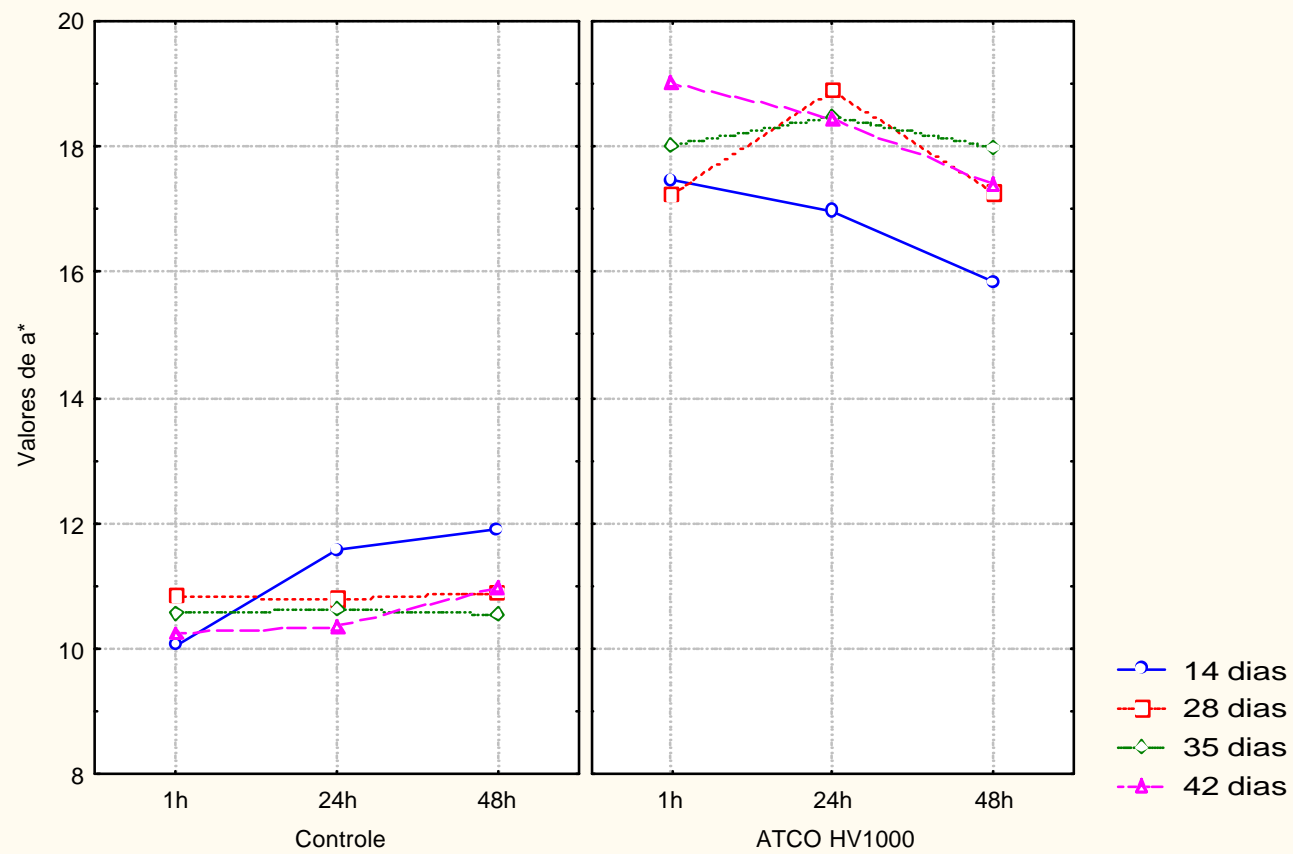

Figura 38 - Efeito do uso de absorvedores sobre a cor vermelha instrumental dos bifes de alcatra, após 1, 24 e 48h de exposição aeróbica.

Aos 14, 28, 35 e 42 dias de armazenamento e após 1h de exposição aeróbica, os valores de $\mathrm{a}^{*}$ das amostras acondicionadas com absorvedores de oxigênio foram 17,45; 17,21; 18,00 e 19,00, respectivamente. A estabilidade da oximioglobina, medida pelo método simplificado de reflectância (R630-R580), foi de 16,15;17,19; 17,78; 17,43, medidos nos mesmos períodos. Esses valores não variaram significativamente ao longo das $48 \mathrm{~h}$ de exposição aeróbica.

O método simplificado de diferença entre as reflectâncias a $630 \mathrm{~nm}$ e $580 \mathrm{~nm}$, revelou que as amostras de alcatra acondicionadas com absorvedores de oxigênio possuíam teores comparativamente superiores de oximioglobina (pigmento típico de carne fresca) que as amostras do tratamento controle, ao longo de todos os períodos avaliados $(p=0,000)$.

A Figura 39 mostra a correlação entre as notas de cor vermelha dos bifes de alcatra e a de reflectância entre 630 e 580nm $(r=0,68)$. 


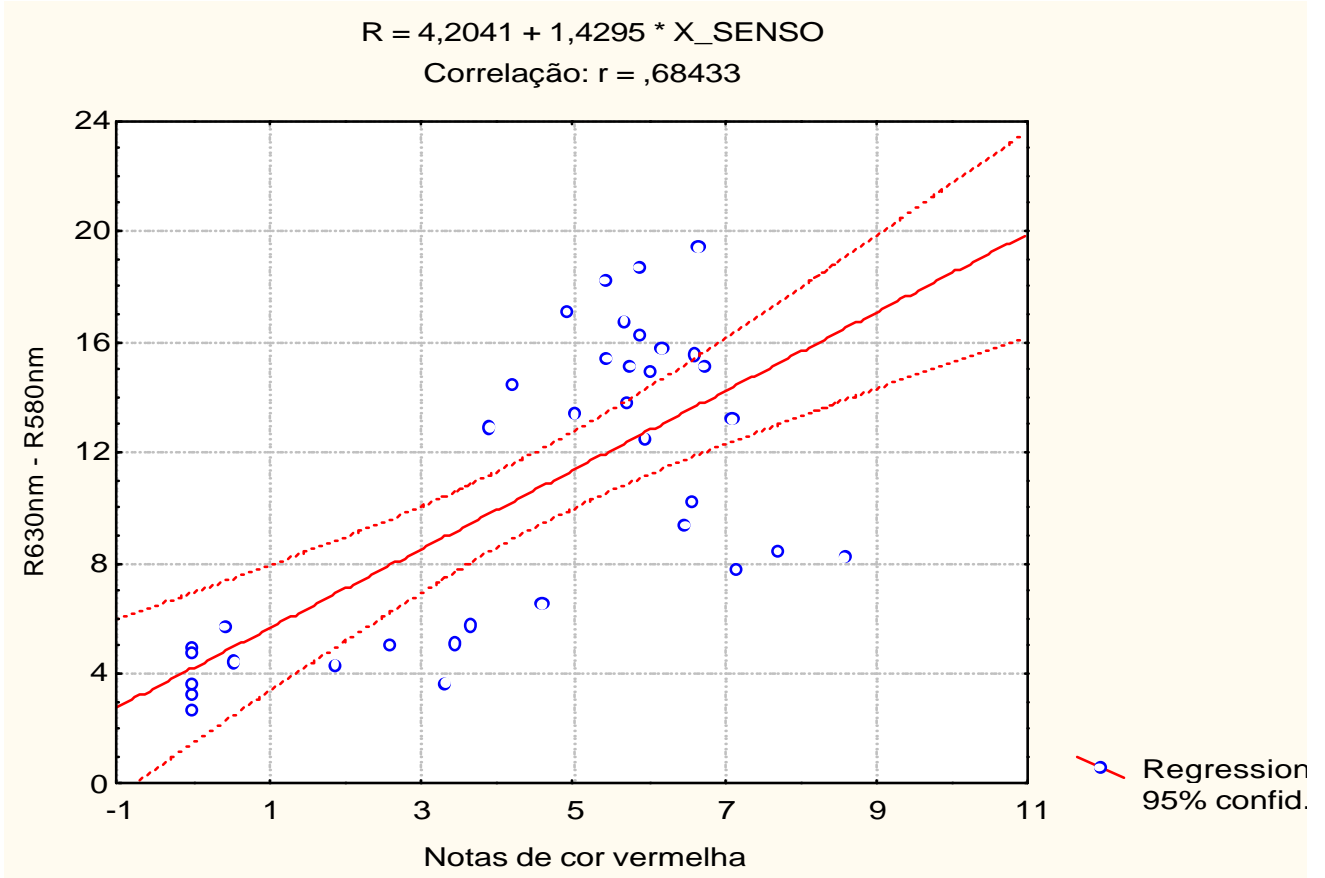

Figura 39 - Correlação entre os valores médios de cor vermelha física e a diferença de reflectância (R630-R580) dos bifes de alcatra ao longo de 42 dias de armazenamento sob $\mathrm{CO}_{2}$ e $48 \mathrm{~h}$ de exposição aeróbica.

A luminosidade dos bifes de alcatra do tratamento controle $(37,25-35,48)$ foi geralmente superior à das amostras acondicionadas com absorvedor de oxigênio $(36,13-$ 30,89), ao longo das $48 \mathrm{~h}$ de exposição aeróbica $\varphi=0,025)$ em todos os períodos de armazenamento (Figura 40). Essa variação pode ser atribuída à cor cinza clara que recobria a superfície dos bifes de alcatra do tratamento controle, uma vez que os bifes armazenados com absorvedores reavivaram a coloração vermelha, característica de carne fresca. 

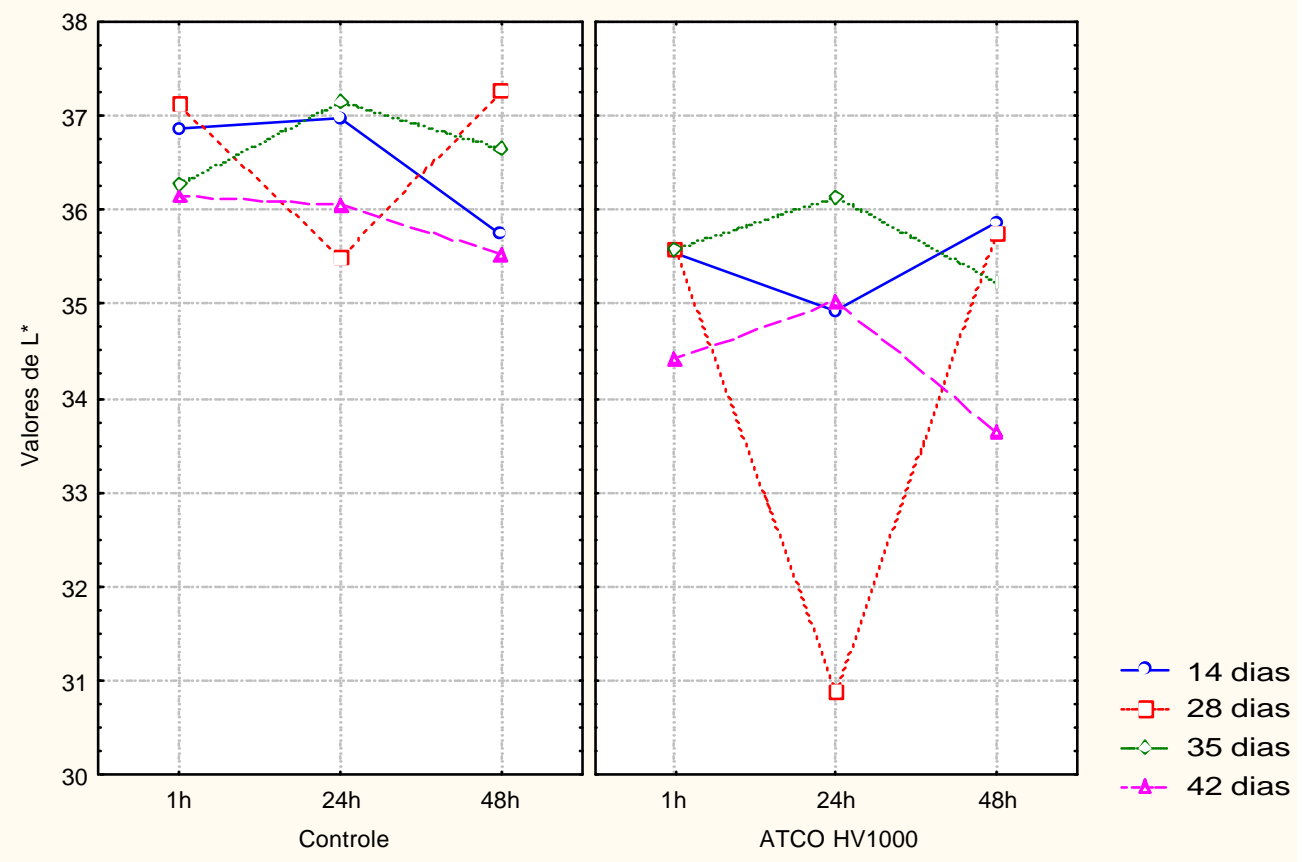

Figura 40 - Efeito do uso de absorvedores sobre os valores de luminosidade (L*) dos bifes de alcatra, após 1, 24 e 48h de exposição aeróbica.

A baixa estabilidade da cor do músculo de alcatra (Longissimus dorsi), associada aos altos valores de vermelho obtidos instrumentalmente e às notas de cor sensorial atribuídas às amostras, revelam o alto potencial de sistemas masterpack com atmosfera modificada e absorvedores de oxigênio em prolongarem a vida útil de cortes de bifes de carne bovina.

Os valores de $b^{*}$ das amostras acondicionadas com absorvedores de oxigênio não diferiram estatisticamente daqueles das amostras do tratamento controle (Figura 41).

Aos 14, 28, 35, e 42 dias de armazenamento e após 1h de exposição aeróbica, os valores de $b^{*}$ dos bifes de alcatra acondicionados com absorvedores de oxigênio foram respectivamente, 8,$32 ; 3,88 ; 5,78 ; 3,88$. Esses valores não variaram estatisticamente ao longo das $48 \mathrm{~h}$ de exposição aeróbica dos períodos avaliados. 

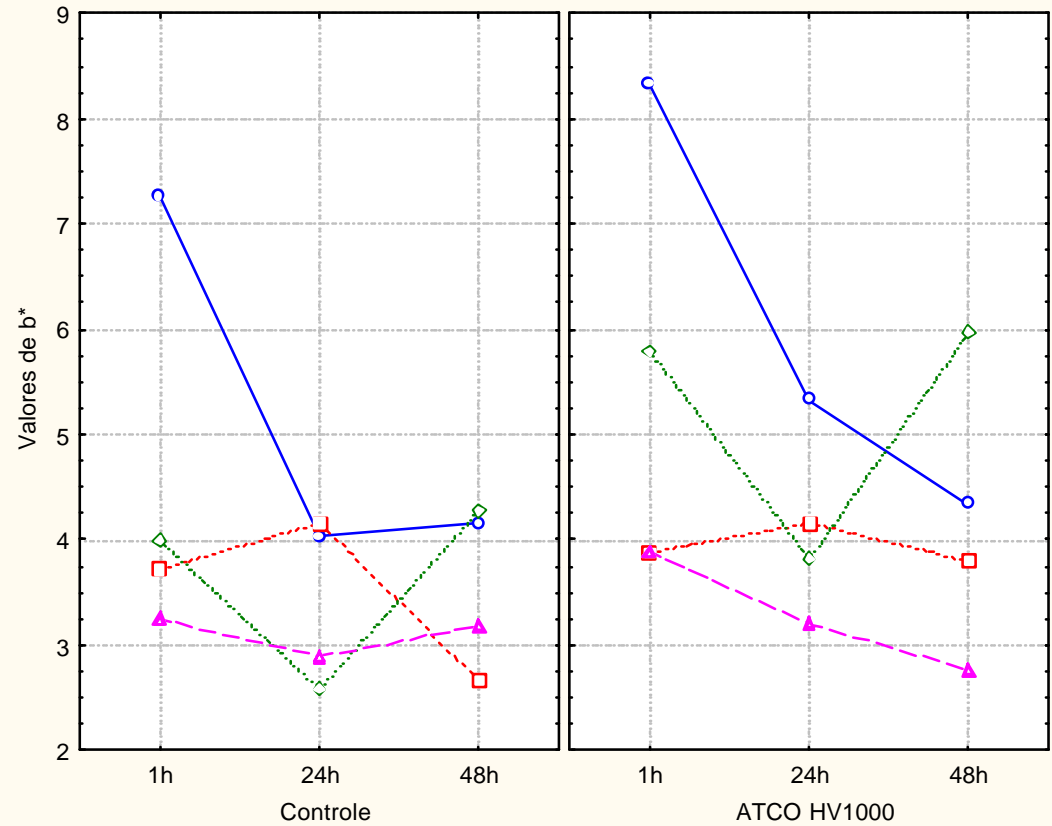

- 14 dias

$-\square-28$ dias

- -35 dias

$-\triangle-42$ dias

Figura 41 - Efeito do uso de absorvedores sobre os valores de $b^{*}$ dos bifes de alcatra, após 1, 24 e 48h de exposição aeróbica.

$\mathrm{Na}$ segunda semana de armazenamento os bifes de alcatra armazenados com ATCO HV1000 apresentaram as maiores frações de manchas (>15\%), menor intensidade de cor rósea na gordura $(3,10)$ e foram julgadas de aparência regular.

A partir da segunda semana de armazenamento os bifes de alcatra acondicionados com ATCO HV1000 apresentaram até 5\% de manchas (Figura 42), gordura rósea mais intensa variando de 4,41 a 5,91 (Figura 43). 

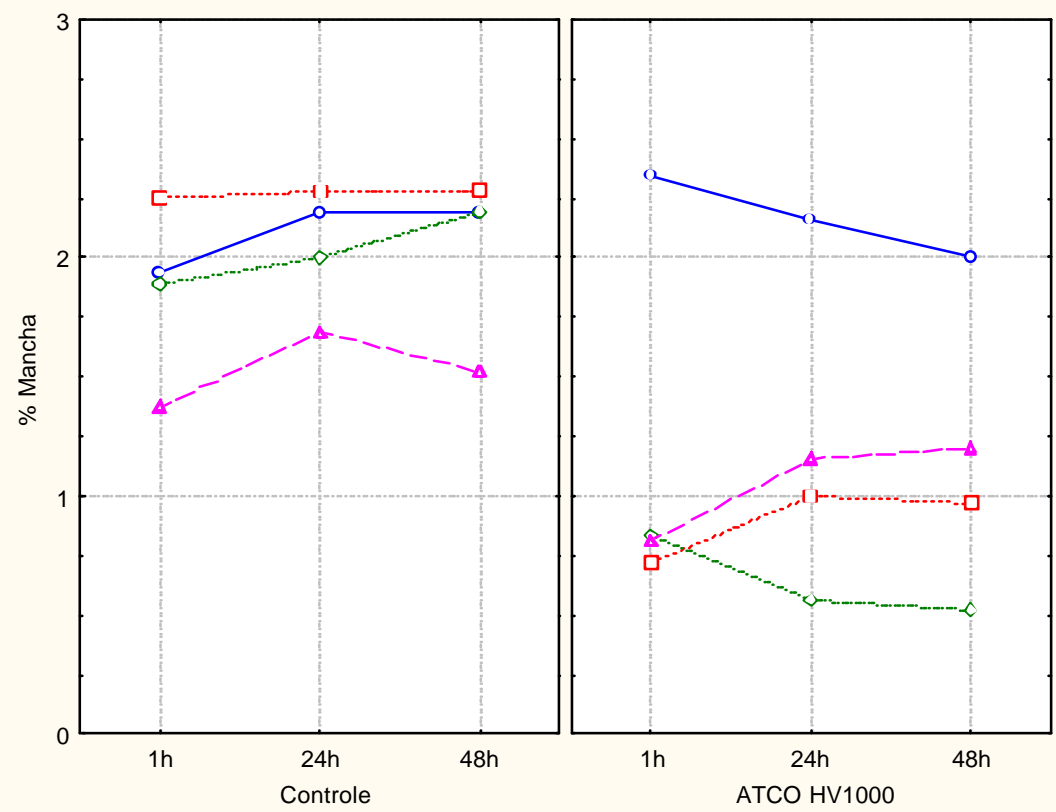

$-\infty \quad 14$ dias
$-\square-28$ dias
$-\checkmark 35$ dias
$-\triangle-42$ dias

Figura 42 - Influência do tempo e do uso de absorvedor sobre a porcentagem de manchas dos bifes de alcatra, após 1,24 e 48h de exposição aeróbica $(0=$ sem manchas, $1=$ até $5 \%, 2=5-15 \%, 3=15-25 \%, 4=$ mais de $25 \%$ ). 

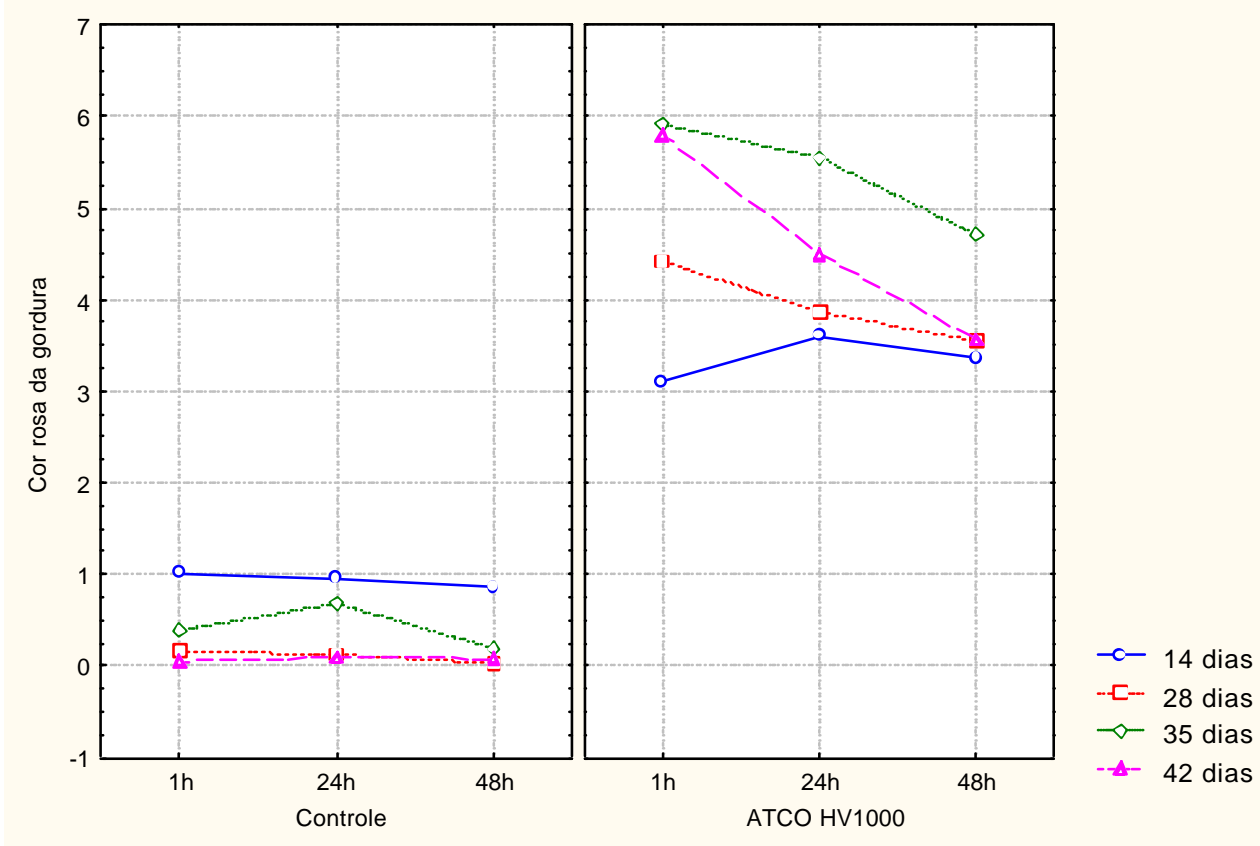

Figura 43 - Influência do tempo e do uso de absorvedor sobre a intensidade da cor rosa da gordura dos bifes de alcatra, após 1, 24 e 48h de exposição aeróbica.

\subsubsection{Teste de aceitação}

$\mathrm{Na}$ avaliação de aceitação realizada em supermercado após 42 dias de armazenamento sob $\mathrm{CO}_{2}$, a maioria dos 80 consumidores percebeu que os bifes de alcatra e contra filé armazenados em masterpack sob $\mathrm{CO}_{2}$ apresentavam grande quantidade de exsudado e eram mais escuros que os cortes frescos, que podiam ser fatiados no momento da escolha do corte no açougue do supermercado (Figuras 44 e 45)

$\mathrm{Na}$ Figura 46 pode ser observado que a cor vermelha dos bifes de contra filé foi relacionada com carne fresca de alta qualidade para a maioria dos consumidores, tendo $77 \%$ de aceitação ("certamente compraria" ou "provavelmente compraria"). 


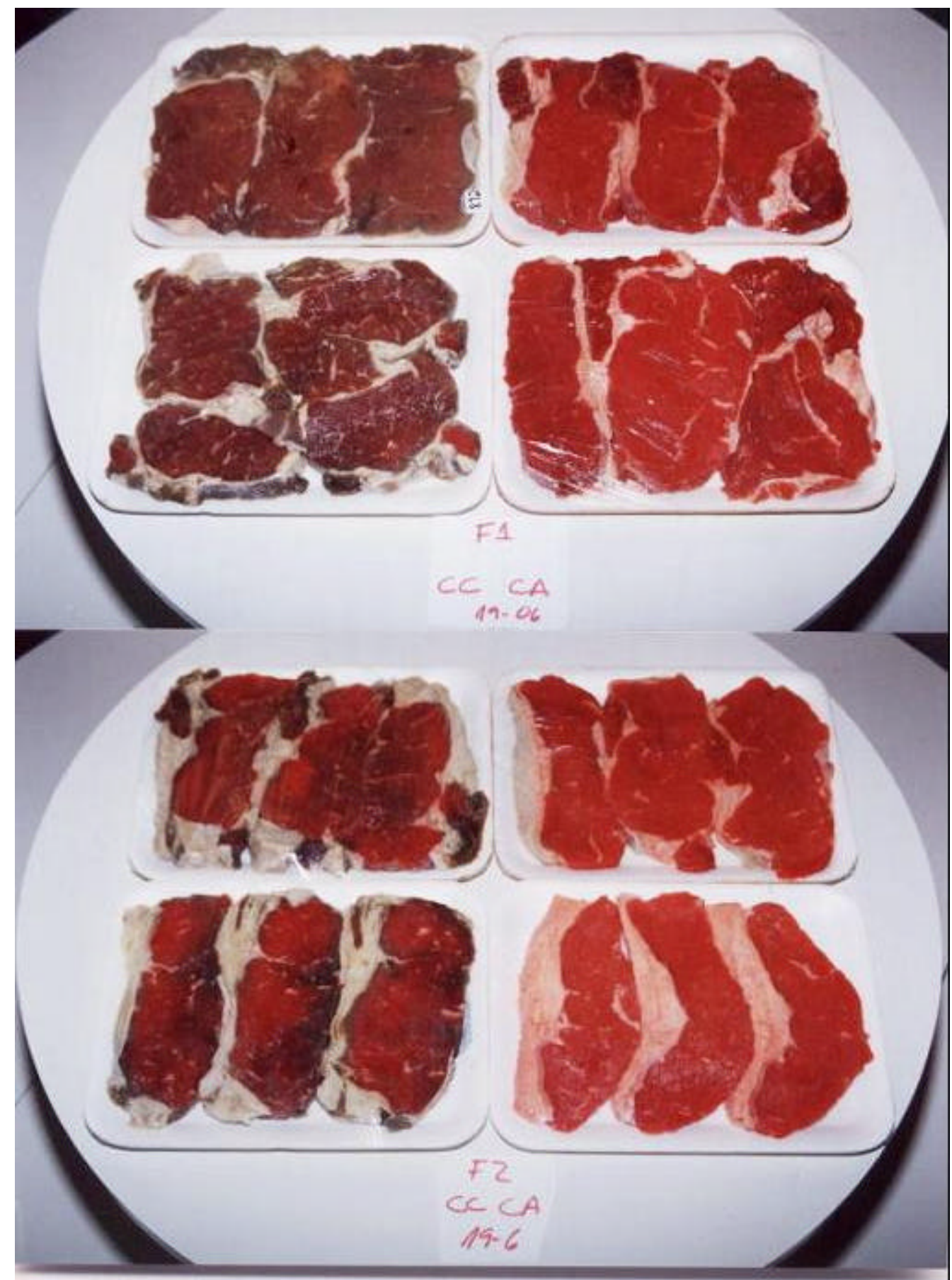

Figura 44 - Amostras de bifes de contra filé armazenados por 42 dias sob $\mathrm{CO}_{2}$, acondicionados sem absorvedor de oxigênio (à esquerda) e com absorvedor de oxigênio (à direita), após 1h de exposição aeróbica. 


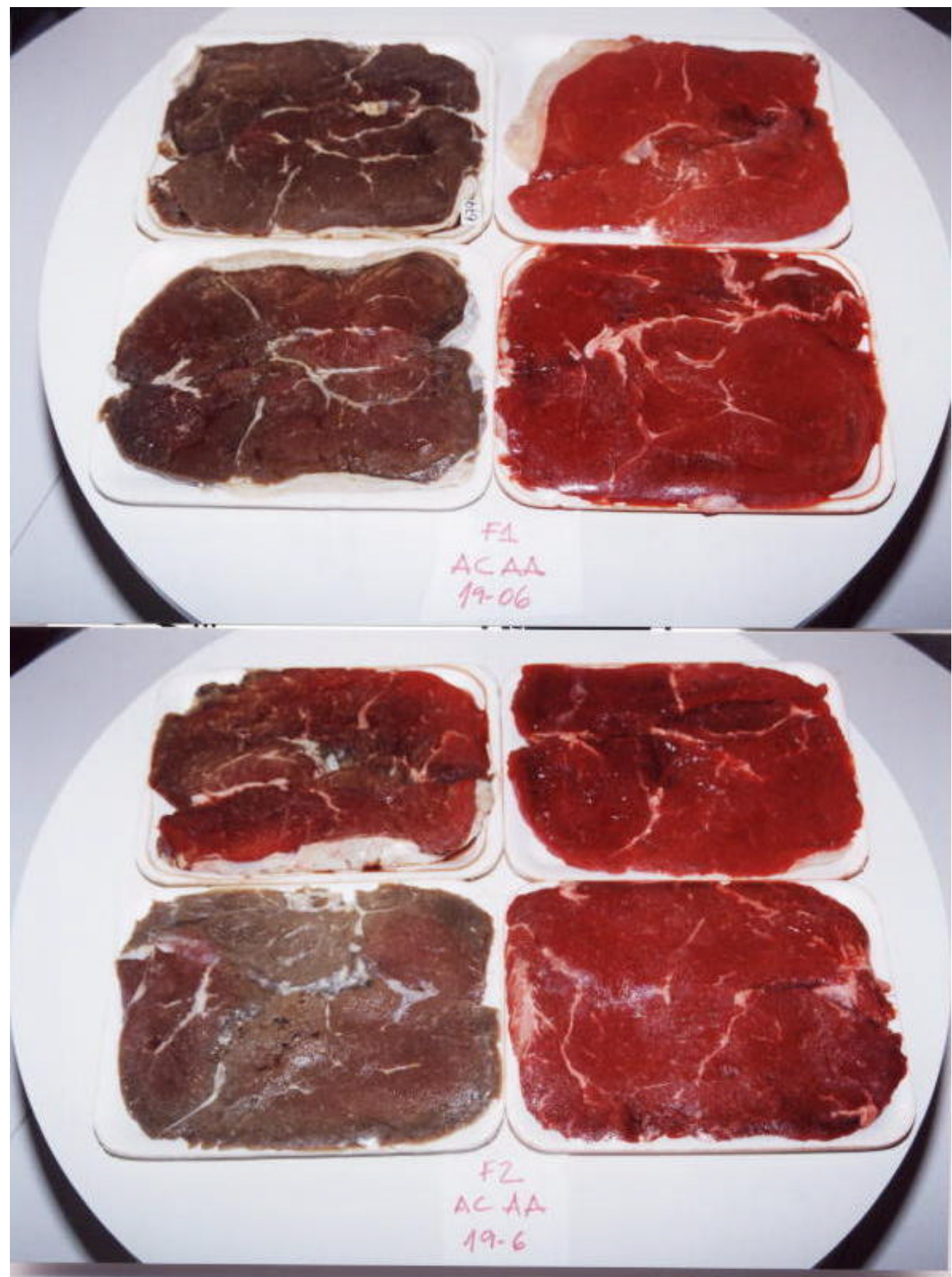

Figura 45 - Amostras de bifes de alcatra armazenados por 42 dias sob $\mathrm{CO}_{2}$, acondicionados sem absorvedor de oxigênio (à esquerda) e com absorvedor de oxigênio (à direita), após 1h de exposição aeróbica. 


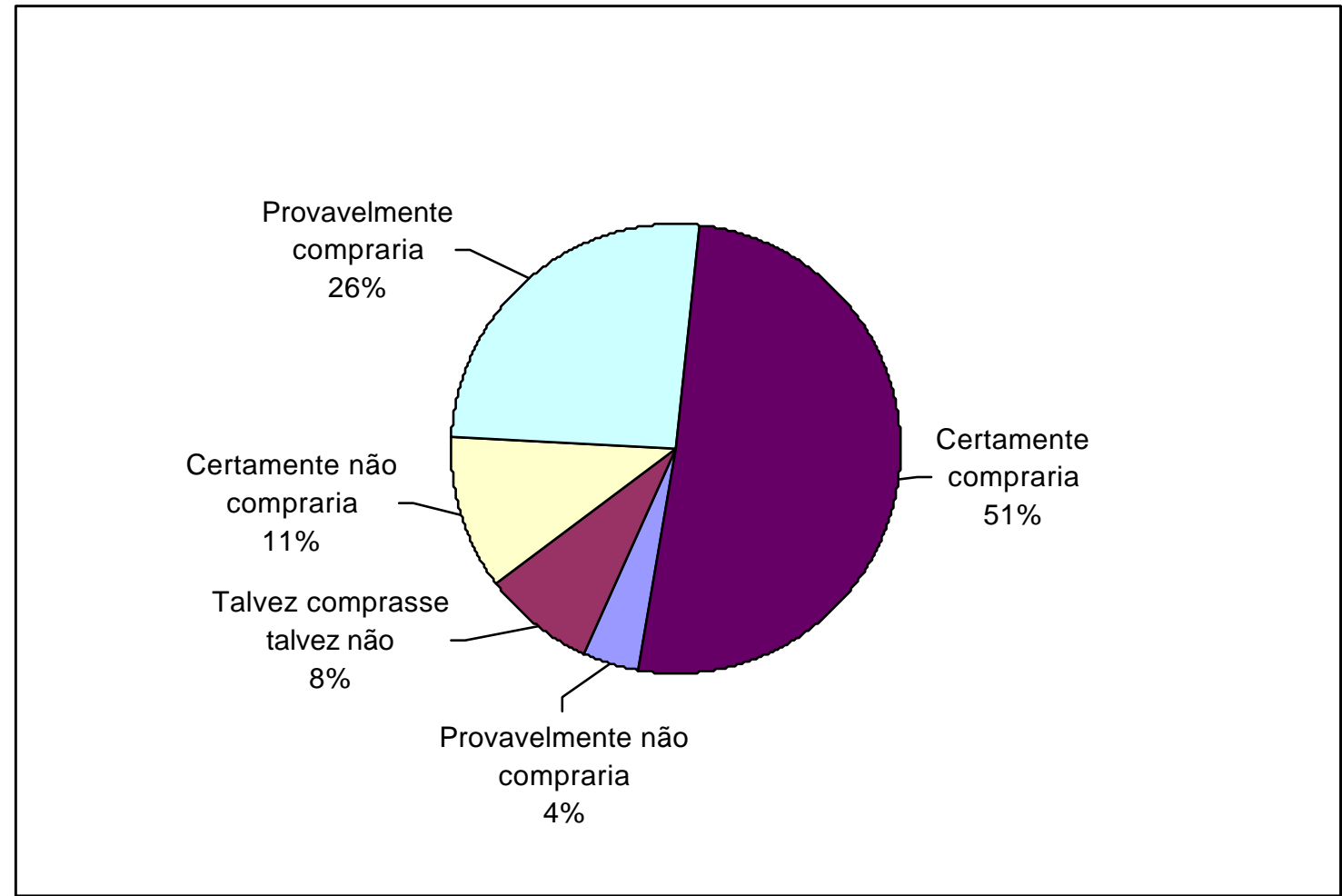

Figura 46 - Porcentagem de aceitação dos bifes de contra filé acondicionados com absorvedores de oxigênio, após 42 dias de armazenamento sob $\mathrm{CO}_{2}$.

Os bifes de alcatra foram rejeitados por $15 \%$ dos consumidores que expressaram que "provavelmente não compraria" ou "certamente não compraria", e $8 \%$ responderam que "talvez comprasse, talvez não". Uma minoria dos consumidores considerou a carne muito vermelha, chegando a questionar a respeito do uso de aditivos para realçar a cor, afirmando que se tratava de carne colorida artificialmente.A porcentagem de aceitação dos bifes de alcatra ("certamente compraria" ou "provavelmente compraria") foi menor (49\%) (Figura 47). 
A percepção de grande quantidade de exsudado nas bandejas provavelmente foi o principal fator que influenciou a rejeição ("provavelmente não compraria") das amostras (41\%). Uma porcentagem de 6\% afirmaram que "não comprariam".

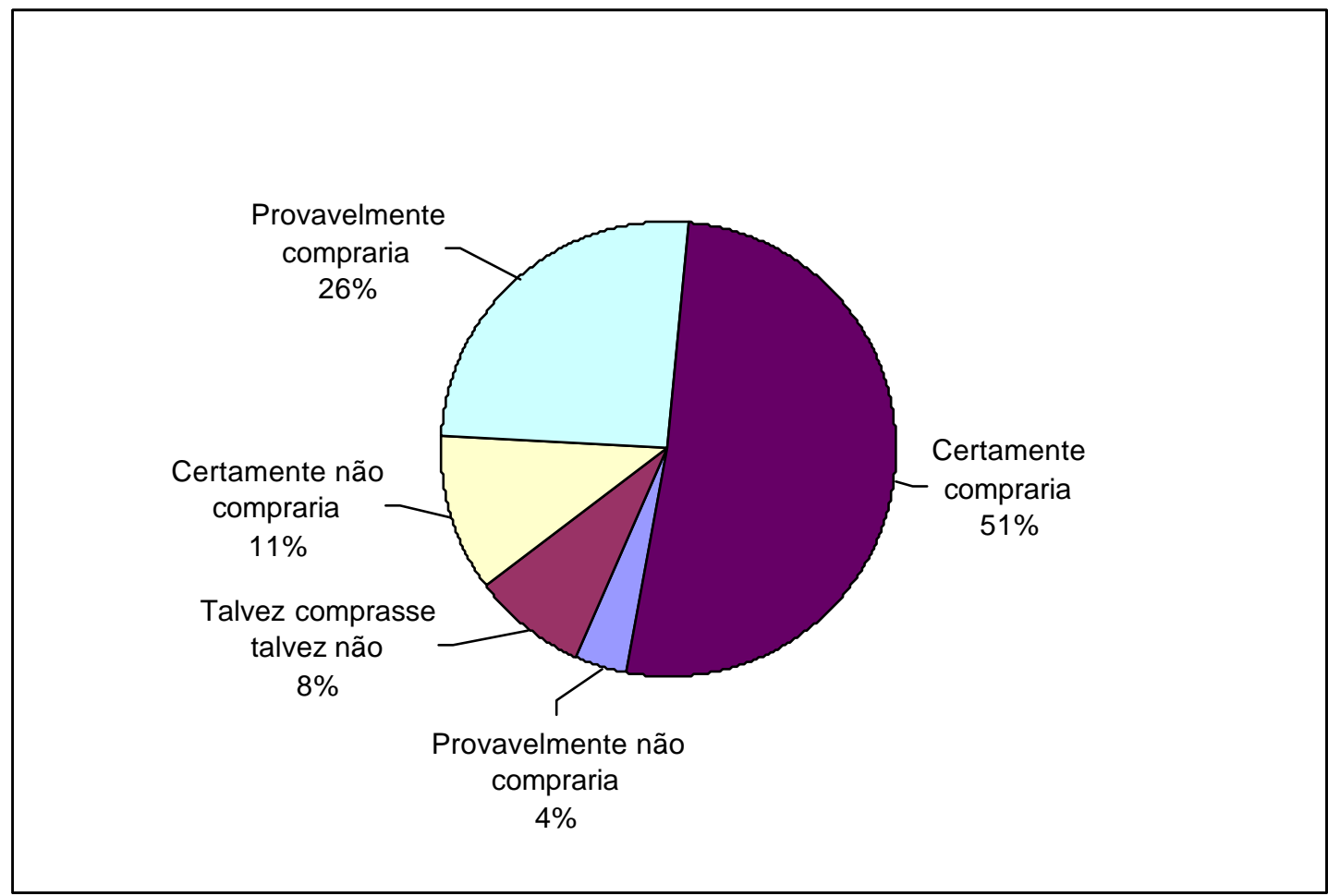

Figura 47 - Porcentagem de aceitação dos bifes de alcatra acondicionados com absorvedores de oxigênio, após 42 dias de armazenamento sob $\mathrm{CO}_{2}$.

Algumas vezes a cor vermelha foi associada à carne de qualidade inferior (escura, velha e dura). Alguns consumidores desgostaram da disposição dos cortes nas bandejas (bifes muito grandes), enquanto que outros observaram que o filme primário não estava em contato com toda a superfície do bife, e que nessas regiões o bife aparentava ser mais escuro ou descolorido. 


\section{CONCLUSÕES}

Absorvedores baseados no princípio de oxidação do ferro com capacidade de seqüestrar $1000 \mathrm{~mL}$ de oxigênio foram os mais eficientes para retardar a oxidação irreversível da mioglobina e aumentar a fase lag da microbiota deterioradora, aumentando a vida útil de bifes de carne bovina, acondicionados em 8 bandenjas de aproximadamente $380 \mathrm{~g}$ de carne armazenada sob atmosfera modificada com $100 \% \mathrm{CO}_{2}$, por até 42 dias.

A redução enzimática da metamioglobina a deoximioglobina e a reoxigenação após exposição aeróbica ocorreu entre o sétimo e $14^{\mathrm{o}}$ dia de armazenamento sob $\mathrm{CO}_{2}$ e somente nas embalagens onde o oxigênio residual não foi excessivo, ou seja, nas embalagens masterpack que continham absorvedores de oxigênio.

A cor vermelha dos bifes de alcatra foi aceitável por 39\% de consumidores após 35 dias de armazenamento que continham absorvedores de oxigênio e $49 \%$ de consumidores após 42 dias de armazenamento sob $100 \% \mathrm{CO}_{2}$ a $1 \pm 1{ }^{\circ} \mathrm{C}$, permanecendo constante por até $48 \mathrm{~h}$ de exposição aeróbica.

A cor vermelha da carne de contra filé foi aceitável por $61 \%$ dos consumidores após 35 dias de armazenamento e por $77 \%$ após 42 dias de armazenamento sob $100 \% \mathrm{CO}_{2}$ a $1 \pm 1^{\circ} \mathrm{C}$, permanecendo constante por até $48 \mathrm{~h}$ de exposição aeróbica.

A menor estabilidade da cor do alcatra (Gluteus medius) em atmosfera modificada em comparação ao contra filé (Longissimus dorsi) é consequëncia da menor capacidade 
de redução da mioglobina inerente ao músculo que está relacionada com sua atividade respiratória e consumo de oxigênio;

Quando as carnes maturadas utilizadas no processamento dos bifes apresentaram elevada contagem microbiana (próxima de $10^{6} \mathrm{UFC} / \mathrm{g}$ ), a cor dos bifes acondicionados com absorvedores de oxigênio permaneceu vermelha apesar da vida útil ter sido limitada pelo número de psicrotróficos aeróbios na superfície dos produtos

A maior vida útil foi obtida quando com a matéria prima para o processamento dos bifes apresentava contagens de psicrotróficos aeróbios $<10^{4} \mathrm{UFC} / \mathrm{g}$

As escalas não estruturadas utilizadas na análise sensorial para determinar as cores marrom e roxa dos bifes de alcatra e contra filé não foram avaliadas estatísticamente devido à inconsistência dos dados em virtude dos termos de intensidade ancorados nas extremidades e no entremeio das escalas que não foram suficientemente compreendidos durante o treinamento dos julgadores. $\mathrm{O}$ mesmo fato impossibilitou a avaliação estatística na análise da cor cinza da gordura. 


\section{REFERÊNCIAS BIBLIOGRÁFICAS}

BORCH, E.; KANT-MUERMANS M-L; BLIXT, Y. Bacterial spoilage of meat and cured meat products. International Journal of Food Microbiology, v.3, p.103-120, 1996.

EGBERT, W.R.; CORNFORTH, D. P. Factores influencing color of dark cutting beef muscle. Journal of Food Science, v.51, n.1, p.58-65, 1986.

FAUSTMAN, C.; CASSENS, R.G. Basis for Fresh Meat Discoloration, Journal of Muscle Foods, v.1, p.217-243, 1990.

GARCÍA-LÓPEZ, M.L.; PRIETO, M.; OTERO, A. The physiological attributes of Gram-negative bacteria associated with spoilage of meat and meat products. In: DAVIES, A.; BOARD, R. (ed.) The microbiology of meat and poultry. New York: Blackie Academic \& Professional, 1998, cap.1-34, p. 269-294.

GIDDINGS, G.G. The basis of color in muscle foods. Journal of Food Science, v.42, n.2, p.288-294, 1977.

GILL, C.O. Extending the storage life of raw chilled meats. Meat Science, v.43, p.99109, 1996.

GILL, C.O. The solubility of carbon dioxide in meat. Meat Science, v.22, p.65-71, 1988. 
GILL, C.O.; McGINNIS, J.C. The effects of residual oxygen concentration and temperature on the degradation of the colour of beef packaged under oxygen-depleted atmospheres. Meat Science, v.39, p.387-394, 1995.

GILL, C.O.; JONES, T. The display of retail packs of ground beef after their storage in master packages under various atmospheres. Meat Science, v.37, p.281-295, 1994a.

GILL, C.O.; JONES, T. The display of retail-packaged beef steaks after their storage in master packages under various atmospheres. Meat Science, v.38, p.385-396, 1994 b.

GILL, C.O.; McGINNIS, J.C.; TONG A.K.W. Consumer acceptance of display packs of beef stored under $\mathrm{N}_{2}$ or $\mathrm{CO}_{2}$ in master packs. Meat Science, v.38, p.397-406, 1994.

GOVINDARAJAN, S. Fresh meat color. Food Science and Nutrition, v.4, p.117-140, 1973.

HOOD, D.E.; MEAD, G.C. Modified atmosphere storage of fresh meat and poultry In: PARRY, R.T.(Ed.) Principles and applications of modified atmosphere packaging of foods. New York: Blackie Academic \& Professional, 1993, cap.11, p. 269-294.

HOOD, D.E. Factores affecting the rate of metmyoglobin accumulation in pre-packaged beef. Meat Science, v.4, n.4, p.247-265, 1980.

HUNT, M.C. Meat Color measurements. Apresentado ao $33^{\circ}$ MEAT CONFERENCE OF THE AMERICAN MEAT SCIENCE ASSOCIATION, Manhattan, 1980. Meat quality measurement systems. Kansas State University: American Meat Science Association, 1980. p. 1-21

HUTCHINGS, J.B. Chemistry of food colour. In: MacDOUGALL, D.B. Food Colour and apperance. Cambridge: Blackie Academic \& Professional, 1994. cap. 10, p.401410: Fresh meat. 
ISDELL, E.; ALLEN, P.; DOHEERTY, A.M.; BUTLER, F. Colour stability of six beef muscles stored in a modified atmosphere mother pack system with oxygen scavengers. International Journal of Food Science and Technology, v.34, p.71-80, 1999.

KROPF, D.H.; HUNT, M.C.; PISKE, D. Color formation and retetion in fresh meat. In: MEAT INDUSTRY RESEARCH CONFERENCE, 21, National Livestock and Meat Board, Chicago, 1985.

LABUZA, T. P. An introduction to active packaging for foods. Food Technology, v.50, n.4, p.68-71, 1996.

LABUZA, T.P.; BREENE, W.M. Aplications of "active packaging" for improvement of shelf-life and nutricional quality of fresh and extended shelf-life foods. Journal of Food Processing \& Preservation, v.13, p.1-69, 1989.

LARRY L.; Reviere, R.D.; Cole, B. Fresh red meats: a place to apply modified atmospheres. Food Technology, v.42, n.9, p.65-69, 1988.

LEDWARD, D.A. Metmyoglobin formation in beef stored in carbon dioxide enriched and oxygen depleted atmospheres. Journal of Food Science, v.35, p.33-37, 1970.

LEDWARD, D.A. Metmyoglobin formation in beef muscles as influenced by content and anatomical location. Journal of Food Science, v.36, p.138-140, 1971.

MARRIOT, N.G.; NAUMANN, H.D.; STRINGER, W.C.; HEDRICK, H.B. Color stability og prepackaged fresh beef as influeced by pre-diplay environments. Food Technology, v.21, n.11, p.104-106, 1967.

O'KEEFFE; HOOD, D.E. Anoxic storage of fresh beef: colour stability and weigh loss. Meat Science, v.5, p.267-281, 1981a. 
O'KEEFFE; HOOD, D.E. Anoxic storage of fresh beef: nitrogen and carbon dioxide storage atmospheres. Meat Science, v.5, p.27-39, 1981b.

PENNEY, N.; BELL, R.G. Effect of residual oxygen on the colour, odour and taste of carbon dioxide-packaged beef, lamb and pork during short term storage at chill temperatures. Meat Science, v.33, p.245-252, 1993.

RENERRE, M. Rewiew: Factores involved in the discoloration of beef meat. International Journal of Food Science and Technology v.25, p.613-630, 1990.

RENERRE, M; MAZUEL, J.P. Relations entre methods de measures instrumentals et sensorielles de la couleur de la viande, Sciences des Aliments, v.5, p.541-557, 1985.

ROUSSET, S.; RENERRE, M. Effect of $\mathrm{CO}_{2}$ or vacuum packaging on normal and high pH meat shelf-life. International Journal of Food Science and Technology, v.26, p.641-652, 1991.

SATERLEE, L.D.; HANSMEYER, W. The role of light and surface bacteria in the color stabilitiy of prepackaged beef. Journal of Food Science, v.39, p.305-308, 1974.

SEIDEMAN, S.C.; DURLAND, P.R. The utilization of modified gas atmosphere packaging for fresh meat: a review. Journal of Food Quality, v.6, p.239-252, 1984.

SCHOLTZ, E.M.; JORDAN, E.; DRUGER , J.; NORTJE, G.L.; NAUDE, R.T. The influence of different centralised pre-packaging systems on the shelf life of fresh pork. Meat Science, v.32, p.11-29, 1992.

SMITH, J.P.; ABE, Y.; HOSHINO J. Interactive packaging involving sachet technology. In: ROONEY, M.L. Active Food Packaging, London: Blackie Academic \& Professional, 1995. cap.6, p.143-172.

STEWART, M.R.; HUTCHINS,B.K.; ZIPSER, M.W.; WATTS, B.M. Enzymatic reduction of metmyoglobin by ground beef. Journal of Food Science, v.30, n.1, p. 487-491, 1965. 
STRANGE, E.D., BENEDICT, R.C., GUGGER, R.E., METZGER, V.G. AND SWIFT, C.E. Simplified methodology for measuring meat colour. Journal of Food Science, v.39, n.2, p. 988-992, 1974.

TEWARI, G.; JAYAS, D.S.; HOLLEY, R.A. Centralized packaging of retail meatscuts: a review. Journal of Food Protection, v.62, n.4, p.418-425, 1999.

TEWARI, G.; JAYAS, D.S.; JEREMIAH, L.E.; HOLLEY, R.A. Prevention of transient discoloration of beef. Journal of Food Science, v.66, n.3, p.506-510, 2001.

VANDERZANT, C.; SPLITTOESSER, D.F. Compendium of methods for the microbiological examination of foods, 3.ed., Washington: American Public Health Association,1992. 1219p.

VERMEIREN L.; DEVLIEGHERE F.; VAN BEEST M.; KRUIJIF N.; DEBEVERE, J. Developments in the active packaging of foods, Trends in Food Science \& Technology, v.10, p.77-86, 1999.

ZHAO, Y.; WELLS, J.H.; McMILLIN K.W. Apllications of dynamic modified atmosphere packaging systems for fresh red meats: Rewiew. Journal of Muscle Foods, v.5, p.299-328, 1994. 